\title{
1 Mud volcanism: an updated review
}

3 Adriano Mazzini ${ }^{1}$, Giuseppe Etiope ${ }^{2}$

${ }^{1}$ Centre for Earth Evolution and Dynamics, University of Oslo, Norway

${ }^{2}$ Istituto Nazionale di Geofisica e Vulcanologia, Sezione Roma 2, Italy, and Faculty of Environmental Science and Engineering, Babes Bolyai University, Cluj-Napoca, Romania

\section{ABSTRACT}

Mud volcanism, or sedimentary volcanism, represents one of the most intriguing phenomena of the Earth's crust, with important implications in energy resource exploration, seismicity, geo-hazard and atmospheric budget of greenhouse gases. Since the first review papers were issued at the beginning of 2000s, a large amount of new geological, geophysical and geochemical data has been acquired, which clarified ambiguous concepts and significantly improved our knowledge of mud volcanism. Here, we offer an updated review of the knowledge and implications of mud volcanoes, with emphasis on: the terminology used to describe different processes and structures; the physical, chemical and morphological characteristics of the several fluid emission structures; the chemical properties of the released fluids, in particular the molecular and isotopic composition of the gas; the mud volcano formation dynamics; and the several implications for petroleum exploration, geo-hazards and global atmospheric methane budget. This review integrates new fluids data collected in Azerbaijan and is complemented with field observations from various mud volcano provinces worldwide.

Although the total number of mud volcanoes on Earth is still uncertain, more than 600 main onshore structures, with a large variety in shapes and sizes, are documented in recent global data-sets, and several thousand are assumed to exist in the oceans. It is clear that: (a) mud volcanoes are broadly distributed throughout the globe in active margins, compressional zones of accretionary complexes, thrust and overthrust belts, passive margins, deep sedimentary basins related to active plate boundaries, as well as delta regions; (b) they are specifically located in hydrocarbon bearing basins, along anticline axes, strike slips and normal faults, and fault-related folds in Petroleum Systems; (c) they represent a specific category of natural gas/oil seepage manifestation, often related to deep and pressurised 
34 reservoirs; (d) the main engine driving mud volcanism is given by a combination of 35 gravitative instability of shales and fluid overpressure build-up, followed by hydrofracturing; 36 (e) hydrocarbons are generally of thermogenic origin, while microbial gas is released in only 37 a few cases. Mud volcanism on other planets (e.g. Mars and Titan), and microbial activity 38 associated with gas seepage represent emerging issues and opportunities for future research.

39 Keywords: Mud volcanoes; gas seepage; diapirism; mobilised shales; morphology; sedimentary basins;

40 hydrocarbons; hydrofracturing; methane; petroleum; seismicity.

41

\section{Contents}

2 Fundamentals: terminology, distribution and morphologies of mud volcanoes.

2.1 Definitions and terminology

$48 \quad 2.2$ Main characteristics

492.3 Global distribution and settings.

$50 \quad 2.4$ Morphologies.

512.5 Internal structure: feeder channel and roots

52

\section{Mud and fluid emission structures}

543.1 Plumbing system and cone structures.

553.2 Gryphons.

$56 \quad 3.3$ Pools

$57 \quad 3.4$ Salsa lakes

$58 \quad 3.5$ Sinter structures

59 3.6 Mud density vs height

$60 \quad 3.7$ Diffuse degassing .

61

4 Fluid temperature and geochemistry

$63 \quad 4.1$ Temperature

64 4.1.1 Insights from temperature readings......

654.2 Molecular and isotopic composition of gas

664.3 Water chemistry

67 4.4 Learning from seasonal sampling and temporal variability

705.1 Gravitative instability, fluid overpressure and hydrofracturing.

715.2 Constraints in modelling

$725.3 \mathrm{MVs}$ and seismicity 
6 Implications

6.1 Hydrocarbon exploration

6.2 Geohazards.

6.3 Methane emission to the atmosphere

7 A leading case-study: the Caspian mud volcanism

80

$81 \quad 8$ Emerging issues and future research

828.1 Mud volcanism on other planets

83 8.2 Seepage and microbial activity

84

\section{Sediment-hosted geothermal systems}

8610 Conclusions

87 References

88

89 Supplementary Material: Methods and data tables 
Mud volcanoes (hereafter reported as MVs) are surface expressions of focused fluid flow inside hydrocarbon-bearing sedimentary basins. They are a specific category of hydrocarbon seeps, connected hydraulically to petroleum (natural gas and oil) rich sediments and accumulations, which may or may not have commercial importance. Mud volcanism, or sedimentary volcanism, represents one of the most intriguing phenomena of the Earth's crust, not least for its implications in energy resource exploration, seismicity, hazard and atmospheric budget of greenhouse gases. MVs can, in fact, (a) indicate subsurface petroleum accumulations, (b) may react to or reveal precursor signals of earthquakes, (c) induce hazards for people and industrial facilities, and (d) release large amounts of methane into the atmosphere. For these reasons MVs, occurring both onshore and offshore, have been the object of wide research since the early 1900s (e.g. Goubkin and Fedorov, 1938). Books and review papers, published since the end of 1990s (e.g. Guliyev and Feizullayev, 1997; Milkov, 2000; Dimitrov, 2002; Kopf, 2002), summarised the basic and important concepts of MVs, describing their distribution, the tectonic settings, activity and products, as well as the mechanisms of formation. However, after those reviews, in the last 15 years, a great deal of new geological, geophysical and geochemical data has been acquired, which clarified ambiguous concepts and significantly improved our knowledge of MVism. The scope of the present review is to provide updated information on the meaning and implications of MVs, some of which have been neglected in previous reviews. Today, the list of peer-reviewed articles dealing with MVs occurring in Europe, Asia, America, Oceania and almost all marginal seas, is immense: it is not the aim of this paper to provide an inventory of all the available works. Rather, our main objectives are to summarise, discuss and provide new concepts regarding:

116 (a) the terminology used to describe different processes and structures, which appear to 117 be confused in some articles (Section 2);

118 (b) the physical, chemical and morphologic characteristics of the several fluid emission 119 structures (Section 3);

120 (c) the chemical properties of the released fluids, in particular the molecular and isotopic 121 composition of the gas (Section 4);

122 (d) the MV formation dynamics (Section 5);

123 (e) the implications of MV for petroleum exploration, geo-hazards and global 124 atmospheric methane budget (Section 6). 
126 As an illustrative case study, we provide an overview of the MVism in the Caspian Basin

127 (Section 7) that a) represents all the main characteristics of a typical geological setting prone 128 to the formation of MVs; b) displays the largest density and variety of MV types on Earth; 129 and c) has been extensively studied for both scientific and petroleum exploration purposes. In 130 this respect, we provide 22 new, unpublished, compositional and isotopic data from four MVs in Azerbaijan. Gas and water samples were collected and analysed in 2005 and 2006, as described in the Supplementary Material. These data confirm and complete some general concepts addressed in Section 4.2.

We then discuss emerging issues and opportunities for future research, including MVism on other planets (Mars and Titan), and microbial activity associated with MV seepage (Section 8). Finally, a short discussion is dedicated to Sediment-Hosted Geothermal Systems (SHGS, Section 9), which are peculiar fluid flow systems incorporating some similarities with MVs, and thus may be confused with them, but that substantially are driven and controlled by different factors, i.e. they do not represent sedimentary volcanism.

\section{Fundamentals: terminology, distribution and morphologies of mud} volcanoes

\subsection{Definitions and terminology}

145

MVs (Fig. 1) are the surface expression of subsurface processes characterised by movements of large masses of sediments and fluids, collectively indicated as "sedimentary volcanism". The subsurface processes, which may or may not give rise to MVs, are generically referred to as "piercement structures", which include diapirs, diatremes, domes, dewatering pipes, mud intrusions, mud mounds, chimneys, pipes (see definition, for example, in Kopf, 2002; and in Skinner and Mazzini, 2009). "Mud volcano" has often been considered as a descriptive term, indicating substantially and generically a surface discharge of mud, water and gas, independent of the geological processes and settings that drive and control the fluid manifestation. As a result, the term was often incorrectly applied to volcanic (magmatic) or geothermal and non-sedimentary settings, resulting in an unintended divergence of consistent 
geothermal system or $\mathrm{CO}_{2}$-rich mofettes in Central Italy have been labelled as MVs (e.g.

158 Etiope and Martinelli, 2009).

159 Etiope and Martinelli (2009) and Etiope (2015) challenged the misuse of the MV term and 160 proposed, following basic and converging discussions in Milkov (2000), Dimitrov (2002), 161 Kopf (2002), a more rigorous criterion in the definition of MV. More specifically the authors 162 highlight four major points that are characteristic of MVs:

163 a) The discharge of at least a three-phase system (gas, water, and sediment - and occasionally 164 oil).

165 b) Gas and saline water related to a diagenetic or catagenetic hydrocarbon production system 166 (accordingly gas is dominated by methane and subordinately $\mathrm{C}_{2+}$ hydrocarbons).

167 c) The involvement of sedimentary rocks with a gravitative instability resulting from rapid 168 sedimentation, leading to the formation of mobile shales, diapirs or diatremes.

169 d) The (common) presence of breccia within the discharged material.

170 MV gas is typically dominated by methane (microbial or thermogenic in origin as discussed 171 in Section 4.2). In some cases, however, gas can be mainly $\mathrm{CO}_{2}$ or $\mathrm{N}_{2}$ where hydrocarbon systems are located close to subducting slabs and relatively high geothermal gradient environments (e.g. Motyka et al., 1989) or are related to the final stages of thermogenic gas generation (Baciu et al., 2007; Etiope et al., 2011a). However, MVs are always associated with, what in petroleum geology literature is known as, "Total Petroleum System" (Magoon and Schmoker, 2000). Accordingly, MVism represents a peculiar form of "petroleum seepage system", as defined by Abrams (2005), and a MV is its surface "seep" expression, often (but not always) linked to natural gas or oil reservoirs (Etiope, 2015). Another typical peculiarity is given by the existence of shale diapirism as a result of gravitative instability and overpressure of low density sediments (mobilised shales), as discussed in more detail in Chapter 5.

182 This MV definition is therefore based on the genetic mechanism, implying the existence of 183 sedimentary volcanism. The term "mud volcano" cannot be used for any gas manifestation 184 resembling a mud pool or where extrusive mud gives rise to small conic edifices, as may happen for certain $\mathrm{CO}_{2}$-vents related to geothermal or hydrothermal environments, as explained above. The issue is not only a semantics problem. The attribution of "mud volcano" to a surface gas manifestation implies the existence of a series of specific geological processes and features. Presently, much MV research is being carried out, including numerous publications in planetary geology (for example, MVism on Mars). 
Erroneous attributions of terrestrial MVs can lead to confusion, misinterpretations and misquotations.

\section{Suggested Location for Fig. 1 MV general}

\subsection{Main characteristics}

The main engine driving the dynamics of MVs (i.e. sedimentary volcanism) is given by a combination of gravitative instability of shales and overpressure of gas in reservoirs or generated at greater depth and migrated through fractures. Other processes may contribute to MV formation and activity, however. A more detailed discussion on MV formation is given in Chapter 5.

MVs episodically experience violent eruptions of large amounts of predominantly hydrocarbon gas (mainly $\mathrm{CH}_{4}$ and, in minor amounts, heavier gaseous hydrocarbons) and low amounts of $\mathrm{CO}_{2}, \mathrm{~N}_{2}, \mathrm{He}$, mixed with water, oil, mud and rock fragments forming the so called "mud breccia". In 1989, after the discovery of the mud diapiric belt in the Mediterranean, Cita et al. (1989) coined the term mud breccia to describe a melange of water, mud and clasts of different size containing a mix of lithologies of the different strata brecciated through the feeder channel. The origin of the erupted fluids and solids varies depending on the geological setting. Petrography and vetrinite-maturity studies of breccias suggest that the roots of some MVs can reach up to 15-25 km (Sobissevitch et al., 2008). However this issue is a subject of debate since elevated sediments buoyancy would be essential to compensate the enormous pressure required to overcome the overburden and allow fluids and sediments to reach the surface from such depths. In this respect, recent studies and simulations have identified the porosity waves as a mechanism by which deep fluids trapped in ductile rocks may be expelled and migrate towards the surface (Connolly and Podladchikov, 2015; Yarushina et al., 2015).

The activity, or typification, of MVs can be divided into four main categories (Mazzini et al., 2009b):

- $\quad$ Eruptive: eruptions can be violent and spectacular events during which sudden bursts of mud breccia reach several tens of meters in height and burning plumes of gas and oil can occur. These episodic violent events are related to the time required by the system to generate 
new overpressure at depth essential to breach the seal in the upper part of the conduit (or region of diffused upwelling). Eruptions commonly last a few days or less.

- Dormant/sleeping: this represents the time interval in between eruptions. The majority of MVs are currently in this condition, generally characterised only by gas and water seepage with variable intensity (including non-visible miniseepage), commonly focused in bubbling pools, gryphons, salsas (see details below). Typically during this quiescence period, the volcano gradually gathers new overpressure at depth.

- Extinct: there is no evidence of recent MV activity; no signs of erupted fluids or solids are documented in historic time. Weak gas seepage can continue to persist.

- Fossil: it refers to paleo-MVs, ancient buried structures observable along stratigraphic sequence revealed by acoustic or drilling techniques (see examples in e.g. Bannert et al., 1992; Delisle et al., 2002b; Clari et al., 2004; Istadi et al., 2009).

\subsection{Global distribution and settings}

MVs are broadly distributed throughout the globe in active margins (compressional zones of accretionary complexes, thrust and overthrust belts), passive margins, deep sedimentary basins related to active plate boundaries, as well as delta regions, or areas involving by salt diapirism. Fundamentally, MVs are located in petroliferous basins and are part of Petroleum Systems (Etiope, 2015).

MVs occur both offshore (e.g. Black Sea, Gulf of Cadiz, Caspian Sea, Mediterranean Sea, Gulf of Mexico, throughout the Indian Ocean, Caribbean Sea, Norwegian Sea, Atlantic Ocean, Pacific Ocean, China Sea) and onshore in many countries (e.g. Jakubov et al., 1971; Barber et al., 1986; Brown and Westbrook, 1988; Cita et al., 1996; Ivanov et al., 1996b; Limonov et al., 1996; Woodside et al., 1998; Dia et al., 1999; Milkov, 2000; Delisle et al., 2002b; Dimitrov, 2002; Kholodov, 2002; Pinheiro et al., 2003; Hensen et al., 2004; Mazzini et al., 2004; Shakirov et al., 2004; Yang et al., 2004; Viola et al., 2005; Baciu et al., 2007; Dupré et al., 2007; Isaksen et al., 2007; Praeg et al., 2009; Bruning et al., 2010; Tsunogai et al., 2012; Chen et al., 2014; Mascle et al., 2014; Hensen et al., 2015; Kirkham et al., 2017). The global distribution of MVs is today known thanks to a long list of discoveries. Among the earliest MV studies we cite those both onshore and offshore in the Caspian region (Jakubov et al., 1971), in the Black Sea (e.g. Ivanov et al., 1989 and Refs. therein) and the 
Mediterranean Sea with the studies of the Prometeus Dome in the western Hellenic arc and the Cobblestone 3 Area (Cita et al., 1981; Cita et al., 1982) followed by the discovery of the diapiric fields, such as the Olimpi field, in the Mediterranean Ridge between 1988-1990 (Cita et al., 1989; Cita and Camerlenghi, 1990). This event triggered huge interest from numerous institutes and opened a new offshore cycle of discoveries. In particular the Russian led Training Through Research Programme (TTR) between 1991-2011 discovered and investigated the Main Mediterranean and Black Sea MV fields (Anaximander field, United Nations Rise in the Mediterranean; Alboran Sea; Tuapse Trough, Sorokin Through, Shatsky Ridge, Andrusov Ridge in the Black Sea). The TTR research extended outside the Mediterranean discovering the large field in the Gulf of Cadiz and further to the north in Norwegian Sea (Ivanov et al., 1992; Limonov et al., 1993; Limonov et al., 1994; Limonov et al., 1995; Ivanov et al., 1996a; Woodside et al., 1997; Kenyon et al., 1998; Kenyon et al., 1999; Kenyon et al., 2000; Kenyon et al., 2001; Kenyon et al., 2002; Kenyon et al., 2003; Kenyon et al., 2004; Kenyon et al., 2006; Akhmetzhanov et al., 2007; Akhmetzhanov et al., 2008; Ivanov et al., 2010). These missions prompted new interest in offshore MVs research and were followed by many other targeted missions and projects, in particular, in the Gulf of Cadiz, Alboran Sea, Anaximander Mountains and Nile Deep Sea Fan (Bellaiche et al., 2001; Mazurenko et al., 2002; Woodside et al., 2002; Pinheiro et al., 2003; Van Rensbergen et al., 2004; Zitter et al., 2005; Berndt et al., 2007; Hensen et al., 2007; Dupré et al., 2008; Lykousis et al., 2009; Magalhães et al., 2012; Mascle et al., 2014). Other offshore known MV areas include the Gulf of Mexico where spectacular asphalt volcanoes are also present, and the region in the Caribbean Islands (Le Pichon et al., 1990; Henry et al., 1996; Olu et al., 1997; MacDonald et al., 2004). It is also worth mentioning the MVs present in Lake Baikal that have been studied during several expeditions and more recently during the new TTR programmeClass@Baikal (Class@Baikal,http://www.baikal.festivalnauki.ru/en). A global seep data-set (Etiope, 2015) indicates that MVs are located onshore in at least 26 countries in Europe, Asia, the Americas and Oceania; none was documented in Africa. MVs are particularly widespread in Romania (about 200 structures), most of which are relatively small and a few meters wide. In Azerbaijan, classic papers report the existence of about 200 onshore MVs (e.g. Guliyev and Feizullayev, 1997) but after checks of synonyms and repetitions, 178 MVs have been listed (CGG, 2015; Etiope, 2015); these are predominantly hundreds of meters in height and covering individual areas of several $\mathrm{km}^{2}$. In Italy, 87 structures have been identified (e.g. Etiope et al., 2007; Martinelli et al., 2012). Most are small mud cones (i.e. muddy gryphons up to a few square meters wide) with the exception of 
the large Maccalube, Santa Barbara, Salinelle at Paternò MVs in Sicily, Nirano, Regnano and other MVs in the Emilia Romagna region. A few to a few tens of MVs are located (in alphabetical order) in Alaska, China, Colombia, Crimea, Georgia, India (Andaman), Indonesia, Iran, Japan, Malaysia, Mexico, Mongolia, Myanmar, New Zealand, Pakistan, Papua New Guinea, Perù, Russia (Taman, Sakhalin, Lake Baikal), Taiwan, Timor Leste, Trinidad, Turkmenistan, and Venezuela (Etiope, 2015 and references therein).

It is however difficult to estimate the exact total number of MVs worldwide because, often, onshore oil/gas seeps or artesian mud seeps are wrongly considered. Likewise many offshore features have only been investigated with acoustic approaches, but sampling is needed to have the unambiguous evidence of a MV feature. Dimitrov (2002) suggests an estimate of 900 onshore and 800 offshore MVs including known and inferred features. Etiope and Milkov (2004) report 926 onshore MVs and consider the existence of at least $300 \mathrm{MVs}$ in shallow offshore (ocean shelves and coastal areas). $652 \mathrm{MVs}$ are actually documented and listed in the global onshore seep data-set discussed by Etiope (2015) (see also CGG, 2015). Fig. 2 provides an overview of the main zones of MVs distribution on the globe. Therefore the map population can be increased significantly if we include also the inferred (i.e. not proved with certitude) offshore MVs, the interpreted diapirs, and the isolated gas, oil, and mud seeps that are often and ambiguously considered as MVs (Kvenvolden and Rogers, 2005; Jerosch et al., 2006; Tinivella and Giustianiani, 2012). Based on observations of MV distribution density, Milkov (2000) suggested that the global number of deep-sea MVs might be in the order of $10^{3}-10^{5}$.

Field observations complemented with the study of satellite images demonstrated that MVs (as with other types of hydrocarbon seeps) are distributed along compressional margins, anticline axes, strike slips and normal faults, and fault-related folds. Faults (especially intersections of two faults) act as preferential pathways for deep fluids to gather and ultimately reach the surface (e.g. see Mazzini et al., 2009a and refs therein). For example numerous MVs onshore in Azerbaijan and in the Caspian Sea are located along the anticline axes (e.g. Jakubov et al., 1971; Bonini and Mazzarini, 2010), or along the Mediterranean ridge (Cita et al., 1989; Mascle et al., 2014), or along strike slips or normal faults in, for example, the Gulf of Cadiz, in Indonesia or along the Apennines (Capozzi and Picotti, 2002; Viola et al., 2005; Mazzini et al., 2009a; Hensen et al., 2015). In particular Mascle et al. (2014) completed a distribution study of MVs in the Mediterranean, Black Sea and Gulf Of Cadiz reiterating that they are preferentially located along faults and tectono-sedimentary 
accretionary wedges, or are characteristic of thick depocenters in the passive continental margins.

\section{Suggested Location for Fig. 2 MAP}

\subsection{Morphologies}

The areal extension of MVs may range from the order of a square meter up to several square kilometres. Periodic eruptions can build up large volcanic edifices, which can reach the width of $4 \mathrm{~km}$ onshore and up to $12 \mathrm{~km}$ offshore (Orange et al., 2009). The highest MV is documented to be up to $\sim 600 \mathrm{~m}$ in height (Yusifov and Rabinowitz, 2004). Estimates of the largest mud breccia volumes erupted by single MVs are up to $12 \mathrm{~km}^{3}$, while narrowly spaced MV complexes can reach volumes up to $250 \mathrm{~km}^{3}$. The mud flows of MV complexes can cover areas as large as $100 \mathrm{~km}^{2}$ (Dimitrov, 2002).

The morphology of MVs is variable and reflects the numerous properties that control the mechanisms of eruption/erosion. Dynamic and mechanical factors include the eruption frequency and vigour. For example, gas-dominated and powerful short-lived blasts tend to disperse the mud breccia over a broader surface resulting in a blocky morphology and relatively poor vertical development due to the lack of substantial solid deposits. Frequent viscous mud breccia eruptions produce large structures similar to the classical conical shapes of the strata volcanoes with numerous superposed flows. Conversely, smooth or flat and laterally extensive morphologies originate from the frequent water-dominated activity of MVs. Finally, the resulting shape can be affected by the width of the shallow conduit (e.g. a wider conduit will disperse the overpressure over a broader surface) and by the depth of the regions of diffused upwelling. Additionally size and morphology can be strongly affected by the pre-existing local topography, and by factors such as type of erosion (e.g. wind, rain, bottom currents - for offshore MVs), rates of basin subsidence, thickness of the affected sequence, and character of the confining strata or structure. Sustained overpressure produced in the subsurface after each eruption may prevent further sagging of the structure and will increase the cyclicity of the eruption. Investigated offshore MVs have overall large sizes and mud breccia flows (although thinner compared to onshore ones) and are capable of extending more laterally due to the low viscosity (i.e. water-saturated conditions) of the erupted sediments and the lack of desiccation processes. 
Because of the large variety in shapes and sizes, it is difficult to provide a defined classification of morphologies. Attempts have been proposed by a few authors based on local studies (Ivanov et al., 1996b; Dimitrov, 2002; Kholodov, 2002; Skinner and Mazzini, 2009) and more generic descriptions are given by e.g. Kopf (2002). Although the morphology of offshore MVs is also affected by different factors, many similarities can be observed with the onshore homologous. Here below, the various classifications are combined and updated (Fig.3, Fig. 4). We complement the published information with observations acquired during our fieldworks in Azerbaijan, Crimea, Trinidad, Romania, Indonesia, Iran, Italy. As Azerbaijan hosts the highest density and the largest onshore MVs, it also represents the ideal location to perform comparative studies of morphological varieties. Therefore particular emphasis and more detailed descriptions will be provided for some Azerbaijani MVs that were investigated during our fieldworks. Their known eruptive activity (documented in Aliyev et al., 2002) and the large scale morphologies observed in the field and with high

- Conical: Most MVs display a cone-shaped morphology that is also similar to that of many classic magmatic volcanoes (Fig. 3A, Fig. 4A). This is characterised by a central circular crater surrounded by superposed units reflecting periodical and frequent vigorous eruptions of low viscosity mud breccia that form the flanks of the cone (e.g., Touragay, Akhtarma, Kalmas, Bolshoi Kyanizadagh, Saryndja, Keyrekie, Boyuk Kyanizadag, and most of the Azerbaijani MVs; Dzuhau-Tepe, in Kerch Peninsula; Chandragup, in Pakistan; Sand, in Iran; MSU, Yuzhmorgeologiya, in the Black Sea; Novorossiysk, in the Eastern Mediterranean; Captain Arutyunov, in the Gulf of Cadiz; Texel, San Remo, in the Mediterranean Sea) (Ivanov et al., 1992; Limonov et al., 1995; Ivanov et al., 1996a). At onshore localities, after each eruption, typically the crater is sealed resulting in following violent explosive bursts with strong tremors and self-ignited methane and hundreds of meters high burning plumes. Inside the crater, seeps of various types may be present and the flanks display tens of meters deep crevasses due to the preferential erosion of fine grained sediment. Several MVs also consist of single or multiple conical gryphons (Fig, 4D, E) typically several 
Touragay (Fig. 4A) is probably one of the classic examples of this type with truncated cone shape and a relatively flat plateau-like crater at its summit. Touragay is considered to be one of the largest onshore MVs with an estimated mud breccia deposit of $343 \times 10^{6} \mathrm{~m}^{3}$. The relatively steep slopes of the volcano present radiating scars with ravines. Its base can reach a diameter of $3.5-4 \mathrm{~km}$ and a height of $390 \mathrm{~m}$. The crater has a diameter of $400 \mathrm{~m}$ where no evidence of active seepage is observed. The major recorded eruptions occurred in 1841, 1901, 1924, 1932, 1947, and 1955.

- $\quad$ Elongated: the shape of these volcanoes (Fig. 3B, Fig. 5D) is strongly affected by tectonic features (e.g. faults, anticlines) that control the collapse of the structure as well as the pathways for the fluids seeping on the surface (e.g. Lokbatan, Pirekeshkul, Arabkadim, in Azerbajan; Faro, in the Gulf of Cadiz; Kazan, in the Eastern Mediterranean Sea (Ivanov et al., 1996a). Bonini and Mazzarini (2010) suggested that the shape of elongated MVs reflects the conditions of different tectonic stresses and the average depth of pressurised source layers.

Pirekeshkul sits to the east of Bojanata Mountain $~ 30 \mathrm{~km} \mathrm{NW}$ of Baku. The MV crater has an elongated shape (50 m wide and $\sim 160 \mathrm{~m}$ long) containing a N-S oriented ridge, of up to $5 \mathrm{~m}$ high active gryphons, that extends along the western flank of the crater. The MV elongated shape and the distribution of the seeps represent a classic example of structures tectonically controlled by the confining Gultamy anticline. No defined crater is distinguishable at Pirekeshkul MV.

Lokbatan (Fig. 5D) is one of the most known MVs due to its frequent fiery eruptions. It is situated approximately $18 \mathrm{~km} \mathrm{SW}$ from Baku in the Absheron region along the LokbatanPuta anticlinal belt that curves towards the NW, also hosting other MVs (e.g. Shongar, Akhtarma Putinskaya, Kushkhana). Lokbatan has an elongated shape that coincides with the direction of the anticline axis and its mud breccia flows cover a surface of $\sim 5 \mathrm{~km}^{2}$. One of the most spectacular recent eruptions occurred on 21 $1^{\text {st }}$ October 2001 (Mukhtarov et al., 2003; Planke et al., 2003) with a large burst of burning methane followed by a massive mud breccia flow that covered a surface of $\sim 0.1 \mathrm{~km}^{2}$. Several meter scale depressions were observed on 
the outskirts of the main crater and are interpreted as impacts of large mud breccia ejecta during this last eruption. Large clasts (up to $0.5 \mathrm{~m}$ in size) can be observed in the mud flows. The main flow also defines a large graben containing horsts resulting in a NW elongated morphology of the MV. Planke et al. (2003) also suggested that this collapse is tectonically controlled by the orientation of the fold and volumetrically affected by the deflation of a shallow chamber after the eruption. Our fieldworks evidenced that this deflation was still ongoing in the crater between 2005 and 2006, as indicated by progressive collapse features within the crater. After the 2001 eruption, burning methane vents and diffuse seepage were observed for several years (e.g. cfr Fig. 6D in Planke et al., 2003; Etiope et al., 2004), but their intensity decreased over time. During our 2005 fieldwork we did not observe burning vents and portable methane sensors did not detect focused and relevant gas plumes. Lokbatan is one of the most active MVs that erupt periodically with a cyclicity of $\sim 5-8$ years. The first documented eruption of Lokbatan goes back to 1829. Other major eruptions were documented in 1864, 1887, 1890, 1904, 1915, 1918, 1923, 1926, 1933, 1935, 1938, 1941, 1954, 1959, 1964, 1972, 1977, 1980, 1990, 2001, 2010 and 2012. The high rate of eruptions and the apparent absence of significant seeps, suggest that Lokbatan is able to seal off the main overpressure generated at depth and facilitate a shorter and more violent eruption.

The other MVs (Kushkhana, Akhtarma Putinskaya, Shongar) located to the NW along the same anticline, also do not show obvious evidence of seepage. Kushkhana and Akhtarma Putinskaya MVs have not been active for a long time (e.g. the most recent eruptions recorded at Akhtarma Putinskaya MV occurred in 1923, 1933, 1950) as also highlighted by the heavily altered mud breccias and the overall strongly eroded structure of the volcanoes.

\section{Suggested location for Fig_4_MV examples}

- $\quad$ Pie-shaped: these MVs (Fig. 3C) have relatively smooth dome-like morphology (e.g. Dashgil, Shongar, in Azerbajan; Dvurechenskii, in the Black Sea, Mercator, in the Gulf of Cadiz).

Shongar MV has a smooth shape that shows evidence of recent mud flows extending radially from the crater (Fig. 5F). As for Lokbatan, evidence of post-eruption collapses is also revealed by distinct crevasses and concentric rings framing the crater. 
Moving $6.8 \mathrm{~km}$ west from the coast line of Cape Alyat, lies Dashgil $M V$ whose crater is aligned with Bakhar and Bakhar Satellite MVs. Dashgil has a smooth pie morphology covering a surface of $5.5 \mathrm{~km}^{2}$ and an absolute height of $\sim 90 \mathrm{~m}$. The volcano has an asymmetric shape with flanks that rise steeply to the crater on the western side, and smoothly dipping flows towards the eastern Cape Alyat (Fig. 5E). The most recent eruptions occurred in 1882, 1902, 1908, 1926, 1958, and minor ones in 2001 and 2011. The western part of the volcano hosts a $200 \mathrm{~m}$ wide crater where numerous pools and large and small gryphons (up to almost 50) are present (Fig. 6A). A ridge of eroded gryphons and active pools occurs further north where an E-W oriented fault defines the outskirts of the crater (Mazzini et al., 2009b). Other faults with the same orientation frame the most recent mud breccia flow (towards the east) and appear to control the position of a large mud cone, and align two large salsa lakes towards the east, located outside the crater. Finally, an elongated ridge of $\sim 3 \mathrm{~m}$ high sinter cones stretches towards the east for $\sim 250 \mathrm{~m}$ and partly frames the two salsa lakes. Interestingly, all these faults are subparallel to the E-W orientation of the main fold (see Fig. 3 in Mazzini et al., 2009b). During the second week of October 2005 stronger activity of most of the seeps was observed for approximately 1 hour. However no correlation was observed with any major seismic event in the region. This presumably represented a diffused sudden release of the overpressure gathered inside the MV. Occasional vigorous gasdominated eruptions occurred in the past, as also indicated by the presence of sinter cones. Nevertheless the numerous seepages scattered throughout the volcano indicate that overpressure and hydrocarbons from great depth (Mazzini et al., 2009b) are constantly released. This permanent overpressure release prevents a gradual pressure build-up, presumably making eruptions less frequent or less vigorous than otherwise expected. For example, in 2001 and 2006, vigorous activities of warm mud eruptions were observed from some of the gryphons in Dashgil and Bakhar respectively. However this activity (that lasted only few days) cannot be defined as an explosive eruption in the classical term. We interpret this as an overpressure release that was not sufficient to trigger a large-scale eruption in sensu stricto but that was rather recycling already open seepage pathways. Another spectacular example of this type of MVs is the Pogachevskiy MV in Eastern Russia, Sakhalin. After its recent eruption on the $18^{\text {th }}$ of August 2015 the nick name of "the gigantic human eye" was given to this structure.

- Multicrater: no defined crater (Fig. 3D) can be distinguished (e.g. Bakhar, in 491 Azerbaijan, Hesperides, in the Gulf of Cadiz). 
Bakhar MV (Fig. 5B) is situated on the easternmost tip of Cape Alyat, located on the crest of the Dashgil fold which also hosts Bakhar Satellite, Dashgil, Koturdag and, towards the east, Geradil MV located offshore in the Caspian Sea (Jakubov et al., 1971). Bakhar mud flows cover a surface of $2.2 \mathrm{~km}^{2}$, but a crater cannot be clearly distinguished. The shape of the MV is irregular and results from mud flows from different eruption sites. Three main eruptive clusters of sparsely distributed pools and gryphons can be defined. The main cluster is situated on the eastern side where the volcano reaches an absolute height of 14 meters. This location marks the most recent eruption that occurred in 1992 when several hundred meters of fire column were blasted in to the air followed by a mud breccia eruption. This mud flow formed an irregular shaped tongue elongating and diving into the Caspian Sea. Two more gryphon and pool fields are present in the western part. The north-westernmost field was found to be particularly active in January 2006 when warm $\left(36^{\circ} \mathrm{C}\right)$ mud breccia flows were vigorously erupting from two gryphons. Towards the south an isolated large active gryphon (mud cone) reaches a height of $\sim 10 \mathrm{~m}$ (Fig. 6C) which represents the highest point of the volcano ( 23m, absolute height). The northern part of Bakhar is crossed by two parallel E-W oriented faults that frame the collapse of a large flow. Bakhar history shows several eruptions. The most significant have been recorded in 1853, 1859, 1886, 1909, 1911, 1926, 1967, and 1992.

When focusing in regions with similar geological characteristics (e.g. Cape Alyat and the Dashgil fold hosting Bakhar, Bakhar Satellite, Dashgil, Koturdag MVs) it is interesting to notice that the structures that display more seepages have fewer eruptions, presumably since a longer period of time is required to gather significant overpressure build-up.

Similarly the Tredmar MV in the Black Sea (Ivanov et al., 1996b) shows an irregular shaped morphology with a presence of a large collapse structure in its southern part.

- Growing diapir-like: are constantly extruding stiff mud breccia from the crater at the rate of tens of $\mathrm{cm}$ to some meters per year (Fig. 3 E). Slickensides along the stiff mud breccia tongues indicate the constant expulsion of sediment. They usually have significant elevation due to the very compacted and stiff material extruded that is difficult to be eroded. (e.g. Koturdag, in Azerbaijan; Raznokol, in Taman Peninsula).

Koturdag $M V$ (Fig. 5C) erects with a $183 \mathrm{~m}$ high conical shape situated $4.5 \mathrm{~km}$ SW from Dashgil. Koturdag represents the classical shape of most MVs with a circular crater $(\sim 220 \mathrm{~m}$ in diameter), collapsed terrace structures on its edges, and mud breccia flows that extend radially on each side of the mountain covering a surface of $\sim 2 \mathrm{~km}^{2}$. The most recent mud 
breccia flow extends from the central part of the crater towards the north. Sinter features are present on the edges of a large portion of the mud breccia tongue indicating the synchronous burning of methane during the extrusion. The activity of the last eruption did not halt in a short period of time, like it normally happens for other MVs, but progressively decreased as can still be seen in the crater, where a diapir-like structure shows the slow squeezing of highly compacted mud breccias as indicated by the striations throughout. Along the contact between the crater and the extrusion of the mud breccia a rim of sustained diffused gas seepage is present. On the eastern side of the crater one isolated gryphon was observed seeping mud, water and gas during October 2005. The historically recorded eruptions occurred in 1966, 1970, 1977. The constant extrusion of such large volumes of very stiff mud breccia suggests that large overpressure is present and that it is likely rooted at great depth, presumably through a fault as highlighted by a cross section image in Jakubov et al. (1971). An offshore analogue for Koturdag MV could be Carlos Ribeiro MV (in the Gulf of Cadiz, and possibly Kula in the Mediterranean Sea) with similar stiff neck shape extending for $\sim 3 \mathrm{~km}$ and rapidly reaching $180 \mathrm{~m}$ in height (Kenyon et al., 2001; Lykousis et al., 2009).

- Stiff neck: these structures are characterised by the presence of vertical tubes composed of carbonate sandstone or stiff mud breccia merging to form organ-type structures, or isolated features resembling chopped tree trunks (Fig. 3F). These circular tubes appear to be the result of multiple extrusions of the liquid sandy pulp through the permeable sandy or clayey plug in the MV crater (e.g. Kobek, Boya-Dagh, in Turkmenian (Kalitskii, 1914; Kholodov, 2002)).

- Swamp-like: are MVs with very low elevation characterised by the eruption of water rich fine grained mud breccia (Fig. 3G, Fig. 4F). The high viscosity of the erupted material does not allow the construction of edifices and the MV develops laterally from a central crater (Astrakhanka, in Azerbaijan, Kipyashchii Bugor, Bulganak in Turkmenistan; Tabin, in 
Gunung Bulag, in Madura, Lipad, in Borneo; Saint Ouen l'Aumône, in the Mediterranean Sea (Kholodov, 2002; Deville et al., 2003; Lykousis et al., 2009)).

- Plateau-like: are structures with relatively low elevation and relatively steep and narrow flanks with a large flat plateau surface occupied by the crater of the MV (Fig. 3H, Fig. 1D). Ring-like structures are typically present in the wide craters where viscous mud breccia is intermittently erupted. The thick mud can eventually overflow to build a positive morphology, however the gradual collapse of the crater may prevent the build-up of significant elevations (e.g. Akhtarma Pashali, in Azerbaijan; Isis, Amon, Menes, in the Eastern Mediterranean (Dupré et al., 2008; Mascle et al., 2014)).

- Impact crater-like: occurring after powerful blasts able to remove the plugging sediments, and followed by secondary deflations and collapse phase of the crater (Fig. 3I, Fig. 4C, G). The elevation is typically low (e.g. Bakhar satellite, in Azerbaijan, Morne Diablo, in Trinidad). The morphology of these structures resembles the impact craters observed on other planets.

Bakhar Satellite MV (Fig. 4C, Fig. 5A) sits $1.7 \mathrm{~km}$ to the west of Bakhar. This volcano is the youngest structure described in the area and has been for long considered a satellite feature connected to Bakhar MV plumbing system. However it defines a distinct shape with mud flows spreading radially over a rugged and boulder-rich surface of $0.5 \mathrm{~km}^{2}$ and reaching a maximum relative height of $\sim 10 \mathrm{~m}$ around the crater. The $78 \mathrm{~m}$ wide crater has an almost perfect circular shape with a $\sim 10 \mathrm{~m}$ deep caldera. One third of the caldera is occupied by a small lake that results from the drainage of the fluids seeping from the three gryphons and from a dozen scattered pools. Collapse terraces along the flanks of the crater reveal the gradual subsidence of the caldera after the powerful explosive eruption that in 1998 blasted away a gryphon field and a large portion of capping sediment. Remains of an eroded and isolated gryphon, active in the past, are visible $255 \mathrm{~m} \mathrm{SW}$ from the crater. This peculiar morphology resulting from a sudden blast, could represent the primordial shape of MVs that, after cyclical eruption evolve in positive and conical shaped structures.

- Subsiding structure: this type of morphology occurs as the result of gradual subsidence in the crater area and the region around the whole MV (Fig. 3J). The MV therefore has typically very low elevation and often the crater zone is occupied by seepage 
features. Radial subsidence structures are often observed rimming the crater zone (e.g. Arabgadim, Akhtarma Pashali, in Azerbaijan; Bleduk Kuwu, in Java; Chirag, in the Caspian Sea, Amsterdam, in the Mediterranean Sea) (Lykousis et al., 2009).

- Subsiding flanks: Gradual subsidence at the flanks of MVs is common, however at some of these structures this phenomenon if very pronounced especially at offshore MVs with moats framing the base (Fig. 3K, Fig. 1E, Fig. 4B, Fig. 5G). This is presumably occurring due to the huge overburden represented by the load of the volcano itself (i.e. at the base of the structure). Seismic images show that it is common to observe a faulted zone coinciding with the edges of the MV structure (e.g. Napag, Iran; Håkon Mosby, Norwegian Sea, TREDMAR, Eastern Mediterranean, many of the MVs in the Gulf of Cadiz, among those e.g. Bojardin, Al Idrissi, Anastasya (Akhmetzhanov et al., 2008; Foucher et al., 2010)).

- $\quad$ Sink-hole type: These MVs consist of a large salsa lake occupying the whole crater where gas bubbling occurs at several locations (Fig. 3L, Fig. 4H). Typically they do not display any elevation and the whole structure essentially appears like a sinkhole (e.g. Naftliche, Sofikam, Incheh, Ain, in northern Iran; Pink Porsykel, in Turkmenistan) (Oppo et al., 2014). The mechanisms forming these types of structures are not well studied and we speculate that a constant collapse occurs due to the constant expulsion of large volumes of gas. The closest morphological analogues are the offshore pockmarks very common in the hydrocarbon rich provinces (i.e. Mazzini et al., 2016 and refs therein).

\subsection{Internal structure: feeder channel and roots}

The internal structure of MVs has been largely debated. The surficial part of the networked conduits terminating as in gryphons, salsa lakes and pools on the surface, is described in section 3. The shallow subsurface may be investigated using Electrical resistivity tomography (ERT) that may provide realistic, albeit strongly smoothed, images of the spatial electrical resistivity distribution (e.g. Istadi et al., 2009; Zeyen et al., 2011; Bessonova et al., 2012). Pioneering geo-electrical studies at MV sites revealed presence of mud chambers, or mud reservoirs, at $\sim 50-100 \mathrm{~m}$ depth typically located below active gryphon structures (Accaino et al., 2007; Lupi et al., 2016). The deeper and more inaccessible geometry of the conduit zone 
where diffused upwelling occurs is commonly explored using geophysical approaches (typically deep 2D or 3D seismic or geo-electrics targeting the shallow surface). Despite the efforts, it is very difficult to obtain clear images inside this feeder zone since this is 1) heterogeneous, consisting of brecciated and mixed lithologies and 2) typically fluid-rich (water/gas) thus attenuating the seismic signal. Therefore it remains unclear if e.g. 1) during the eruptive phases the movement of solids and fluids occurs through a system of networked large fractures distributed inside the feeder zone, or if 2) their whole cylindrical structure is involved in the mass movement. Combing information from seismic images, estimates of flow rates during the eruption, and maximum size of the erupted clasts, it appears that the first scenario is more plausible (Collignon et al., 2016). Likewise, remains unsolved the hypothesis of the presence of additional shallow chambers where fluids overpressure is periodically recharged and released after each eruption or, for example, at the surface seepage sites. Shallow seismic images of MVs show the so-called "Christmas tree" structures (Fig. 1C) which may be interpreted as evidence of various superposed eruptive events intercalated by hemipelagic depositional sedimentary events. Some authors suggest that these "wings" could represent clastic intrusions rather than effusive events.

\section{Mud and fluid emission structures}

\subsection{Plumbing system and cone structures}

The morphology of the MVs, their distribution, typology, and varying geochemistry of the seepage sites, give insights into the eruption mechanism and the subsurface plumbing system. Field observations conducted in several MV provinces on different continents consented to classify the different seepage features that develop in the craters after powerful eruptions. Three main seepage features can be observed in the onshore dormant craters of the studied MVs: gryphons, pools and salsa lakes. At these sites water, gas, oil and mud seep with different intensity, mode and proportions. No obvious patterns or correlation in seepage activity was observed even at neighbouring sites inferring intricate pathways in the subsurface. The factors controlling the seepage of fluids are still largely debated and the alternatives suggested involve the changes of atmospheric pressure, tidal or seismic events, or 
and salsa lakes are usually permanent structures; the others are prone to become eroded, occluded, or to change position following variations of the permeability of the subsurface seepage system. Sinter structures represent ignition of seeping fluids (i.e. methane) on the surface. Onshore Azerbaijani MVs display all these features.

\subsection{Gryphons}

Gryphons are positive features with a conical shape (Fig. 6). Here gas, water, oil and mud are continuously expelled with variable density and volume. These structures normally gather in fields or cluster in the central part of the crater or follow trends controlled by tectonic features (e.g. faults) like in the Dashgil, Pirekeshkul MVs. In e.g. Bakhar MV, where a defined crater is not distinguishable, gryphons are grouped in fields (Fig. 5B) that correspond to the locations where the most recent eruptions occurred.

\section{$\underline{\text { Suggested Location for figure } 6}$}

The body of the gryphons consists of layered superposed mud flows resulting from the semicontinuous mud eruption. The dipping of the flanks commonly reach angles $>45^{\circ}$ (depending on the grain size and density of the erupted material). These structures may occur in clusters of several units or as single isolated features and may vary in height from few tens of centimetres and are commonly not taller than $\sim 3-4 \mathrm{~m}$. Exceptionally high gryphons can reach $>10 \mathrm{~m}$ in height (e.g. Fig. 6C). These tall structures may also be called mud cones.

The position of gryphons can regularly mutate due to the continuously evolving plumbing system in the subsurface, seepage mode, and the way the surface sediments react to these changes. For example, during arid and hot periods when the seepage of fluids is combined with high evaporation, the upper part of the gryphon conduits can dry up and become cemented. If a newer overpressure is not able to pierce through the old conduit, the fluids will find a new pathway fracturing through the flanks of the cones. This process will initiate a new cone that, with time, will build up and incorporate the older structure (Fig. 7 TOP).

Other factors that significantly affect the morphology of the gryphons are the meteoric phenomena. For example, when the erosion caused by the rain (the most important factor) exceeds the amount of mud and clasts erupted, the gryphon will be flattened and its 
undisturbed development will be altered. Only gryphons with vigorous activity will maintain the steep shape of their flanks. Kholodov (2002) report the presence of carbonate-cemented sediments (Kobek MV) resulting in stiff neck gryphons less erodible than those composed of loose mud. Similar structures are also described at Boya Dag MV (Kalitskii, 1914). During their growth, neighbouring gryphons can merge forming larger structures with multiple seepages in the crater and, on a larger scale, can result in ridges giving insights about the preferential orientation of the seepage sites (e.g. Dashgil, Pirekeshkul MVs). Onderdonk et al. (2011) reported detailed and periodical 3D monitoring of gryphons evolution suggesting that considerable subsidence is ongoing at these sites.

\section{Suggested Location for figure 7}

Three different types of gryphons could be identified depending on the amount of water, gas, sediment/mud breccia ejected (Fig. 6): the splatters, the bubblers and the "clast-rich" (Fig. 7 BOTTOM).

- The spatters are normally characterised by a narrow crater pierced by a void conduit from which mud bursts periodically (sometimes ejected up to a few meters in the air) forced by the pulsating gas overpressure. At these sites the water content is commonly limited and the mud has a high viscosity (Fig. 6G).

- $\quad$ The bubblers have larger craters (occasionally up to few meters in diameter) filled with mud through which gas bubbles with pulsations. Mud periodically overflows once the pool in the crater becomes full (Fig. 6D-E).

- $\quad$ The clast-rich gryphons are the tallest and usually erupt dense sediment containing clasts (Fig. 6F). At these sites the eruption of mud breccia is vigorous and the temperature measurements of the spewed fluids reveal constant values during the day and the seasons (see section 4.1 on $\mathrm{T}$ readings).

Several of the described metre-scaled gryphons have been sectioned in order to verify their internal structure. The excavations showed that below the crater of the splatters, exists a sizable conduit that connects to an internal muddy chamber where gas gurgles more or less continuously allowing the periodic gushing or mud splats towards the surface. Even the 
bubbling gryphons show an internal chamber (although smaller) and a narrower conduit compared with the splatters. This narrow conduit acts as a continuous bypass for the rise of mud and gas in the crater where a muddy pool remains gathered during the continuous bubbling. No internal chamber was observed at the clast-rich gryphons that are fed by deeper rooted conduits.

\subsection{Pools}

Pools are subcircular seepage features without or with low elevation that can be isolated or, more commonly, distributed at the feet of the gryphons. The diameter of the pools may vary from few centimetres up to around a meter and they are usually shallow (centimetres up to few tens of $\mathrm{cm}$ ). At these sites, water is continuously released together with gas and a minor amount of fine grained sediment. Interestingly, pools situated a few tens of centimetres apart can seep fluids with a different composition revealing much higher e.g. oil content (Fig. 8 A, B, E) indicating a distinct plumbing system in the close subsurface. Some of these pools were drained and sectioned in order to describe the internal structure. Observations show that most of the pools, in particular the small ones, have a typical funnel shape with a central conduit (Fig. 8C, D, G). The larger pools $(>50 \mathrm{~cm})$ where vigorous gas seepage may occur, reveal indentations all around the margin suggesting progressive erosion by the turbulent flow and gradual expansion of the pool (Fig. 8F).

Similarly to what was observed at gryphon sites, numerous pools have an episodic seepage activity normally lasting up to one minute during which a vigorous release of fluids occurs. The newly formed pools are often observed due to the strikingly different colour of the seeping mud (typically light grey) compared with the surrounding brownish oxidised mud on the surface (Fig. 8G).

Mazzini et al. (2009b) interpreted in their Figure 7 the plumbing system of gryphon-pool complex based on field observations and gas/water analyses. As most of the pools are consistently located around the gryphons, it is suggested that the overburden of the gryphons causes collapse and fracturing through which the deep fluids migrate, mixing with shallow meteoric waters. At gryphon sites, evaporation is likely to have a limited influence as gryphons contain dense mud and differ morphologically (e.g. from pools) "isolating" the fluids inside the crater and in the internal chambers. $\delta^{18} \mathrm{O}$ values of gryphons' waters support 
a confined seepage of fluids through the feeder channel allowing a bypass through the intervals charged with meteoric fluids.

\section{Suggested Location for figure 8}

The pulsating behaviour of single seepage sites has been observed also during offshore monitoring (e.g. Akhmetzhanov et al., 2007). This is interpreted as the continuous inflation and deflation of the conduit system once a sufficient overpressure is reached and fluids burst out.

\subsection{Salsa lakes}

Salsa lakes (Fig. 9) are not a common feature in MV craters. Like pools, these are subcircular gas and water seepage sites that can reach several tens of meters in diameter and several meters in depth. The large amount of gas and water vigorously venting at these sites, allows the lakes to last through the years despite the seasonal evaporation. Typically a small amount of mud is seeping at these sites. Classic examples can be observed e.g. in Dashgil MV (Fig. 9A-B) where two salsa lakes measure $\sim 30 \mathrm{~m}$ and $15 \mathrm{~m}$ in diameter and respectively $\sim 10$ and $\sim 9$ m deep (Delisle et al., 2005). Another example can be observed in the central part of the Garadag MV crater where large bubbles of mud spurt in a $\sim 15 \mathrm{~m}$ wide lake (Fig. 9C) or the large lake at the centre of Ain MV (Iran) reaching a diameter of $50 \mathrm{~m}$.

Attempts to monitor the amount of methane released from one of the Dashgil salsa lakes was conducted by positioning a floatable raft on the top of the main venting point (Delisle et al., 2005; Kopf et al., 2010b; Kopf et al., 2010a). The results revealed that an average of 70 1/min of methane is continuously vented from the salsa lakes with frequent stronger pulsations releasing the gathered overpressure, presumably from a deeper seated chamber and sometimes related with seismic activity.

\section{Suggested Location for figure 9}

\subsection{Sinter structures}


Sinter structures are the evidence of vigorous and constant seepage of burning methane. This process presumably initiated after the self-ignition of venting methane and continued with the baking of the erupted mud breccia. This results in black to reddish brown coloured molten mud breccia. When this burning process occurs at gryphon sites, it will result in the formation of sinter cones (e.g. Fig. 10A-D). If instead the burning methane is localised at the edges of a large mud breccia flow, sinter striations will indicate the direction of the burned mud flow (e.g. Koturdag MV, Fig. 10 E-F). Diffused sintering may occur in the crater where multiple seepage sites persist once the eruption of mud breccia is terminated (Fig. $10 \mathrm{G}-\mathrm{H}$, e.g. Lokbatan MV).

\section{Suggested Location for figure 10}

\subsection{Mud density vs height}

The density of the erupted mud and detailed measurements of the seeping features have been collected at numerous locations in Azerbaijan, Indonesia, and Trinidad. Measurements at all localities show that taller structures erupt denser mud. Overall a statistical distribution of the topographic elevation versus the density of the erupted mud shows two main clusters. The low elevation pools are grouped within density values between $1-1.2 \mathrm{~g} / \mathrm{cm}^{3}$, while the height of the gryphons increases consistently with the density of the erupted mud. Measurements of gryphons in several MVs set this threshold at $1.2 \mathrm{~g} / \mathrm{cm}^{3}$.

\subsection{Diffuse degassing}

In addition to the visible fluid manifestations described above, MVs also release gas through invisible and diffuse exhalation from the muddy ground. Such an invisible gas emission is called "miniseepage" (Etiope et al., 2011b). Miniseepage is a sort of degassing halo that surrounds the vents, but for many MVs it extends throughout the muddy area. Measurements of gas flux along profiles in MVs suggest that miniseepage can spread over tens of thousands of square meters and that the total, integrated, output of gas to the atmosphere may be higher than that from focused, visible emissions. For example, at the Tokamachi MV in Japan (Etiope et al., 2011b), methane flux from the miniseepage surrounding bubbling pools and 
gryphons is almost three times higher than the flux from visible bubble plumes. Positive $\mathrm{CH}_{4}$ 825 fluxes, from tens to thousands of $\mathrm{mg} \mathrm{m}^{-2} \mathrm{day}^{-1}$, were recorded over $4,900 \mathrm{~m}^{2}$, up to $90 \mathrm{~m}$ from the MVs crater. The total methane output from macro-seepage (the sum of emissions measured from all vents) was estimated to be approximately 5 tonnes/year. Total gas output from miniseepage, derived using spatial interpolations between individual gas measurements (e.g. using the "natural neighbour" interpolation technique), yielded an output of approximately 16 tonnes of $\mathrm{CH}_{4}$ per year. Therefore, more than $75 \%$ of total methane emissions from the MV occurred from miniseepage surrounding visible vents. Similar observations were reported for MVs in Taiwan, Italy, Romania (Baciu et al., 2007; Etiope et al., 2007; Hong et al., 2013).

\section{Fluid temperature and geochemistry}

\subsection{Temperature}

The main factors that seem to control the temperatures recorded at the seepage sites can be summarised as: 1) water-sediment content, 2) exposed surface area of the seep itself and affected shallow volume, and 3) origin of the seeping fluids. As will be described in the following sections, the temperature can be affected by other factors such as the air surface temperature, the local heat flow, and gas flux. Therefore temperature readings can be a useful tool to study the behaviour of dormant MVs. To our knowledge there is no record of temperature readings at the crater zone of erupting MVs. Although not from the crater, Mukhtarov et al., (2003) documented measurements of up to $75^{\circ} \mathrm{C}$ along mud breccia flows at the flanks of Lokbatan MV after the 2001 eruption. The only successful attempt to measure the temperature of an active mud eruption is documented by Mazzini et al. (2007) at the Lusi eruption site in Indonesia $\left(\sim 100^{\circ} \mathrm{C}\right)$. It should be noted however, that at this locality there is a high geothermal gradient $\left(42^{\circ} \mathrm{C} / \mathrm{km}\right)$ unlike the typical sedimentary basins where MVism is common. In fact, it is important to note that the Lusi eruption, ongoing since May 2006, should not be considered a MV but rather a sediment-hosted hydrothermal system (see also 854 following chapters and Mazzini et al., 2012).

855 Offshore measurements have been completed e.g. at Isis MV (Mediterranean Sea) and Håkon 856 
857 Feseker et al., 2008; Feseker et al., 2009). More than a year (431 days) of monitoring at 858 Håkon Mosby MV revealed 25 pulses of hotter subsurface fluids accompanied by small 859 eruptions which represent similar events to those observed onshore during the dormancy of 860 MVs (Feseker et al., 2014). Campaigns completed at the K-2 MV in Lake Baikal showed the 861 presence of gas hydrates and revealed the presence of low and high thermal anomalies that 862 are interpreted to result from a shallow fluid circulation that interacts with a dynamic hydrate 863 system just below (Poort et al., 2012).

864 Overall, seeps temperature readings at onshore dormant MVs reveal typical values rarely exceeding $30^{\circ} \mathrm{C}$. The complexity of the interpretation of temperature measurements at seepage sites has been discussed by Mazzini et al. (2009b). The authors highlighted the importance of differentiating between a) the type of seepage (e.g. pool, gryphon, salsa) and b) warm or cold field season. Generally, pools targeted for measurements reveal varying temperatures in contrast with gryphons that have more stable and higher values. Similar and comparable conclusions were reached by Svensen et al. (2009a) and by Mazzini et al. (2011) after seasonal measurements. Deville and Guerlais (2009) pointed out that dormant seeps are effected by slight temperature variations attributed to clogging and unclogging of deep fractures that periodically facilitate the rise of hotter fluids and higher mud/gas content.

\subsubsection{Insights from temperature readings}

Our repeated seasonal temperature measurements in 2005 and 2006 indicate that all the seepages are affected by the diurnal temperature variations, however this occurs in a different manner.

Pools reveal variations from a maximum of $21^{\circ} \mathrm{C}$ during the mild season, to a minimum of $0.6^{\circ} \mathrm{C}$ during the winter, showing that their temperature is strongly controlled by external conditions. Gryphons are instead less affected by diurnal and seasonal temperature variations as observed by repeated measurements during two extreme seasons. Earlier on, we suggested that many of the large gryphons are the result of the merging of smaller structures. This is also supported by the fact that inside some large gryphon craters up to fifteen distinct seepages were observed, each one with diverse temperature with difference $>3^{\circ} \mathrm{C}$.

888 Our nine months monitoring at Dashgil MV salsa lakes (Fig. 11) showed strong variations in 889 the temperature values at $4 \mathrm{~m}$ depth. The highest $\mathrm{T}$ values $\left(23.5^{\circ} \mathrm{C}\right)$ were recorded at the 890 beginning of July, while the lowest $\left(4.2^{\circ} \mathrm{C}\right)$ at the beginning of February. Although partly 
discontinuous, the record of the air temperature shows a similar trend with cyclical fluctuating values with a minimum reached on $25^{\text {th }}$ January $\left(-5.3^{\circ} \mathrm{C}\right)$ and a maximum on $15^{\text {th }}$ April $\left(30.9^{\circ} \mathrm{C}\right)$. Statistical analyses and the cross-correlogram for air temperature versus water temperature (detrended time series) reveal a delay of 5.05 days of the water values compared with air values. The same temperature monitoring was tested with a thermometer deployed at $\sim 1.5 \mathrm{~m}$ depth. The values revealed daily variation of the fluids that are consistent with the air variation, with a delay of around 4-5 hours.

To summarise, our comparative measurements of different types of seeps suggest that the large seasonal temperature variations observed at pool sites are interpreted as the result of several factors. These water-dominated features are characterised by small dimensions and are thus easily affected by external temperature. For example, the lowest temperatures are reached at smaller pools during the winter time. Furthermore, previous research (Mazzini et al., 2009b) also demonstrated that pool sites have a water composition heavily controlled by meteoric fluids thus indicating that the presence of deep hotter fluids (if present) is largely overprinted. In contrast, gryphons have deep originating seeping fluids, thus explaining the fairly constant seasonal mud temperature at these locations. Other crucial factors are the larger size of the gryphons and the high amount of sediment expelled, conferring high heat retention. We interpret the temperature behaviours of the salsa lake as a result of two combined factors: 1) the large water mass present in the salsa and 2) the air temperature. The salsa water temperature is almost completely controlled by air temperature. The delay and the dampening/smoothing of the curve is due to slow heating and cooling of the large water mass. Moreover, the average air and water temperatures are of comparable magnitude, although the water generally has slightly warmer values. Again this could be ascribed to the delay during the overall cooling trend. If this is the case, any heat input from deeper units must be small compared with the heat exchange with the atmosphere. Mazzini et al., (2009b) revealed a mixed origin of the pools' water, including deep and shallow fluids, but the presented temperature readings indicate that the flux of deep (warmer) fluids is not sufficient to significantly affect the large water mass present at salsa lake sites.

\section{Suggested Location for Fig 11 Tlog}

\subsection{Molecular and isotopic composition of gas}


The gas released by MVs is the typical hydrocarbon-rich natural gas of the petroleum-bearing sedimentary basins. Methane is the main gaseous compound, often above 80 vol.\%, followed by carbon dioxide $\left(\mathrm{CO}_{2}\right)$, nitrogen $\left(\mathrm{N}_{2}\right)$, other alkanes (ethane to butane) and trace amounts of helium (He) (e.g. Milkov et al., 2003; Etiope et al., 2009a). The gas can be thermogenic, produced by thermal degradation of organic matter or oil cracking (catagenesis) in relatively deep sediments at temperatures typically up to $230-240{ }^{\circ} \mathrm{C}$, or microbial, produced at lower temperature and in more recent or shallower sediments (diagenesis) by methanogenic microbes (domain of archaea, not bacteria), utilising $\mathrm{CO}_{2}$ reduction or acetate fermentation pathways (Whiticar, 1999). We do not use the ambiguous term "'biogenic" since in different disciplines (biology, petroleum geology, astrobiology) it was used as synonymous with either "microbial" or "thermogenic". Microbial and thermogenic gas is termed "biotic" because of its derivation from biologic compounds, mainly lipids and carbohydrates, liberated from marine and terrestrial organic matter. Abiotic gas is instead generated by magmatic and gaswater-rock reactions (e.g., Fischer-Tropsch type reactions) that do not directly involve organic matter (Etiope and Sherwood Lollar, 2013).

940 A worldwide statistical evaluation of the stable $\mathrm{C}$ and $\mathrm{H}$ isotope composition of $\mathrm{CH}_{4}$ and $\mathrm{C}_{1} /\left(\mathrm{C}_{2}+\mathrm{C}_{3}\right)$ (methane/ethane+propane) ratio indicates that $76 \%$ of onshore $\mathrm{MVs}$ release thermogenic gas $\left(\delta^{13} \mathrm{C}_{\mathrm{CH} 4} \approx-46.4 \%\right.$ VPDB as average of $\left.201 \mathrm{MVs}\right)$. Only $4 \%$ of MVs release microbial gas $\left(\delta^{13} \mathrm{C}_{\mathrm{CH} 4}<-55 \%\right.$ VPDB), and 20\% release mixed gas (Etiope et al., 2009a) (Fig. 12A-B). Our new molecular and isotopic composition data from four MVs located in different oil field regions in Azerbaijan (Dashgil, Bakhar, Pirekeshkyul and Koturdag MVs; see Supplementary Material) are within the thermogenic range. More detailed studies should verify, however, whether some of the gas considered microbial because of ${ }^{13} \mathrm{C}$-depleted composition, can actually be an early mature thermogenic gas (often neglected in natural gas geochemistry), which may have $\delta^{13} \mathrm{C}_{\mathrm{CH} 4}$ values as low as $-70 \%$ VPDB (e.g. Milkov and Dzou, 2007). The fact that MVs gas is mostly thermogenic is a direct consequence of the processes and environment leading to mud (sedimentary) volcanism. Most sedimentary basins hosting MVs are characterised by high sedimentation rates in Cenozoic time (more than $1 \mathrm{~km} / \mathrm{My}$ ), significant thicknesses of undercompacted sedimentary cover (several $\mathrm{km}$ ) and overpressure, which are favourable conditions for mud diapirism and volcanism. Almost always, MVs are connected with deep hydrocarbon reservoirs whereby gas derives from mature source rocks, within or after the "oil window" maturation level. MVs releasing microbial gas are, instead, generally the result of rapidly subsiding Pliocene-Quaternary 
basins (more rare conditions), with mobilised shales associated to neo-tectonic compressional stress and faulting.

While the isotopic composition of $\mathrm{CH}_{4}$ released by MVs is approximately the same of $\mathrm{CH}_{4}$ at the reservoir (i.e. there is no significant isotopic fractionation during the advective gas migration in fault-controlled seepage systems), the molecular composition is often different and characterised by a $\mathrm{C}_{1} / \mathrm{C}_{2}+$ ratio (the Bernard ratio) higher than that of the reservoir (Etiope et al., 2009a). Molecular fractionation by advection is a sort of distillation (differential segregation) of light hydrocarbon molecules as a function of their adsorption and solubility properties. The effect is that gas seeping to the surface has less ethane and propane (i.e., it is dryer, with a higher $\mathrm{C}_{1} /\left(\mathrm{C}_{2}+\mathrm{C}_{3}\right)$ ratio) than the original. By comparing $\mathrm{MV}$ gas and reservoir gas it has been observed that molecular fractionation is typical of slow degassing MVs, because ascending gas significantly interacts (with longer residence times) with water and sediments (Etiope et al., 2009a). Secondary methanogenesis, following oil biodegradation, can also lead to increased $\mathrm{C}_{1} /\left(\mathrm{C}_{2}+\mathrm{C}_{3}\right)$ ratios (e.g. Milkov and Dzou, 2007; Etiope et al., 2009b).

Our new data from the four MVs in Azerbaijan (Table S1A) confirm these phenomena, as illustrated in Fig. 12A. All MV gas samples (except one, as explained below) have a higher Bernard ratio compared to the original gas of the main reservoirs (e.g., Dashgil oil field) in the area. In particular the Dashgil MV data show that the more fractionated samples (with higher $\mathrm{C}_{1} /\left(\mathrm{C}_{2}+\mathrm{C}_{3}\right)$ ratio) are released from vents located on the peripheral sectors of the $\mathrm{MV}$, while the vents in the central crater sectors show a lower $C_{1} /\left(C_{2}+C_{3}\right)$ ratio closer to that of the subsurface reservoir. Similar results are obtained from seepage sites on the outskirts of the craters of other MVs. Although more data would be necessary to confirm this type of lateral variation, we may provisionally hypothesise that marginal and flank vents, related to secondary channels, may release gas that has experienced higher residence time in the subsurface, thus longer water-gas-mud interactions, which in turn may lead to enhanced molecular segregation. The sample with the lowest $\mathrm{C}_{1} / \mathrm{C}_{2+}$ ratio $(\sim 25)$ measured at Koturdag MV (AZ06-27 in Supplementary Material), is quite unusual for MVs (see a global data-set in Etiope et al., 2009b). This geochemical feature seems to be strictly related to the extraordinary type of the seepage and its migration channel. A diffuse but vigorous seepage of gas occurs along the $\sim 35 \mathrm{~m}$ long contact between the crater and the extrusion of compacted mud breccia (Fig. 10E-F). This seepage is dry, without significant water discharge. We suggest that at this location, a large volume of highly compacted mud breccia is extruded (although slowly) due to the large overpressure of deep rooted gas. We envisage that this gas 
has a direct connection with deep accumulations from which methane is able to rise quickly towards the surface with the mud breccia along the feeder channel. This channel is produced and maintained as very permeable by the contact with the active diapir. The data also confirm previous studies (Mazzini et al., 2009b) in showing that the gas composition at each MV is not related to the type of seepage (i.e. gryphon, pool, salsa). The main factor controlling the molecular composition is the phase (gas vs liquid) and intensity (flux vs residence time) of the emission (Etiope et al., 2009a; Etiope et al., 2011b).

Basically, a low flux MV can be considered as a "natural refinery". Vigorous and erupting MVs, instead, have the same molecular composition of reservoir gas. The "Bernard" ratio is in fact lower during MV eruptions: the ratio changed from 630 to 140 during an eruption of the Regnano MV (Italy) in 1998 (Etiope et al., 2007). Similarly, the ratio of Dashmardan MV in Azerbaijan varied from 9790, before its eruption of September 1976, to 591 during the post-eruptive high-flux state. The same phenomenon is reported for Trinidad where the $\mathrm{C}_{2+}$ concentration was higher in the MVs with more recent eruptions (Deville et al., 2003).

Not considering this alteration mechanism may lead to severe mistakes in interpretations of gas origin. For example, if the stable carbon isotopic composition of methane, $\delta^{13} \mathrm{C}_{\mathrm{CH} 4}$, is not analysed, high $\mathrm{C}_{1} / \mathrm{C}_{2+}$ ratios, with high $\mathrm{CH}_{4}$ content (for example, above 95 vol.\%) relative to ethane and propane, may lead one to think that the gas is microbial. In fact, many MVs have a Bernard ratio typical of microbial gas ( $>500)$, but isotopic data and petroleum system evaluations clearly indicate that the gas is, instead, thermogenic (e.g., Etiope et al. 2009a). As a result, since it does not always reflect the original gas composition, the "Bernard ratio", may be misleading when applied to MVs.

\section{Suggested Location for Fig. 12 gas water chem}

Another important characteristic of MV gas is the frequent occurrence of "heavy $\mathrm{CO}_{2}$ ", i.e., $\mathrm{CO}_{2}$ with positive $\delta^{13} \mathrm{C}$ values, often $>5 \%$ VPDB (Fig. 12C). $\mathrm{CO}_{2}$ occurring in thermogenic hydrocarbon reservoirs, generally a by-product of kerogen maturation in catagenesis (Hunt, 1996), has negative $\delta^{13} \mathrm{C}$ values typically ranging from -15 to $-25 \%$ (Jenden et al., 1993; Etiope, 2015). Heavy $\mathrm{CO}_{2}$ is instead a residual $\mathrm{CO}_{2}$ after consumption by secondary methanogenesis that follows oil biodegradation in relatively shallow ( $<2000 \mathrm{~m}$ deep) 
reservoirs. Oil biodegradation by microorganisms gradually destroys n-paraffins (n-alkanes or normal alkanes) and oil density and viscosity increase. These modifications have negative economic consequences for oil production and refining Petroleum biodegradation is considered to occur in many conventional oil reserves and its detection by heavy $\mathrm{CO}_{2}$ (and ${ }^{13} \mathrm{C}$ enrichment also in $\mathrm{C}_{2+}$ alkanes; Etiope et al., 2009b and references therein) in MVs in explorative areas may help in the evaluation of the quality of subsurface reservoirs prior to drilling. The new data of the four Azerbaijan MVs (Supplementary Material) show the variability of $\delta^{13} \mathrm{C}_{\mathrm{CO} 2}$ values within the same $\mathrm{MV}$; this may suggest that the different vents of a MV can be related to different circulation systems: some vents are located in correspondence with oil-saturated (where oil is biodegraded) structures, others not. This is consistent with the general recognition that MV systems may not be uniform, but can be structured in different sub-systems and isolated blocks (Feyzullayev and Movsumova, 2001). However, variations of $\delta^{13} \mathrm{C}_{\mathrm{CO} 2}$ with time for the same vent, observed in Etiope et al. (2009b), and the fact that $\delta^{13} \mathrm{C}_{\mathrm{CO} 2}$ variability has also been observed directly in gas reservoirs (Pallasser, 2000) suggest that $\mathrm{CO}_{2}$ carbon isotopes are intrinsically highly unstable and can be affected by multiple gas-water-rock interactions. The "heavy" $\mathrm{CO}_{2}$ of Koturdag $\mathrm{MV}$ (Supplementary Material) is associated to ${ }^{13} \mathrm{C}$-enriched ethane and propane (compared to the reservoir), which suggests biodegradation of oil along the seepage system, above the main reservoir.

Finally, as mentioned in Section 2.1, the concentrations of $\mathrm{CO}_{2}$ or $\mathrm{N}_{2}$ in some MVs may be higher than that of $\mathrm{CH}_{4}$. This may be the result of mixing with geothermal gases, especially when the sedimentary basin is adjacent to volcanic or high heat flow regions; or due to effects of source rock over-maturation. High $\mathrm{CO}_{2}$ concentrations (exceeding 20 vol.\%) were reported for MVs in Crimea (up to 64 vol.\%), Russia (up to 29 vol.\%), and Trinidad (up to 25 vol.\%) (Etiope et al., 2009b and references therein). $\mathrm{N}_{2}$-rich gases are released during the final stage of gas generation, after $\mathrm{CH}_{4}$ formation has ceased. Large $\mathrm{N}_{2}$ amounts can also be produced by the metamorphism of clayey, ammonium-containing, sedimentary rocks and magmatic sources (Zhu et al., 2000; Etiope et al., 2011a). Examples of $\mathrm{N}_{2}$-rich MVs are found in Papua New Guinea ( $\leq 76$ vol.\%; Baylis et al., 1997) and in Romania (up to 98 vol.\%; Etiope et al., 2011a). 


\subsection{Water chemistry}

The origin of waters expelled from MVs is not always easy to track down. Throughout the kilometres-sized vertical conduits, chemically distinct formation waters from different sedimentary intervals mix, interact, and react between each other and with the different rocks and sediments to produce a complex cocktail that is finally expelled at the MV surface. For these reasons the composition of MV waters is dramatically different from that of the nearby non-MV environments.

There are mostly three main original sources of water at dormant MVs that get mixed during the burial history of the sediments or during the rise through the piercing systems of diffused upwelling. Mazzini et al (2009b) provided an overview of the origin of these three waters erupting at different seepage features within the MV craters. The main characteristics of each one of these three groups can be described as follows: (1) marine or fresh pore water mechanically entrapped during the fast burial of the source sediments. Depending on the porosity of the entrapping sediments and on the sedimentation rates, the presence of e.g. significant amounts of marine pore waters may increase the total salinity (i.e. $\mathrm{Na}, \mathrm{Cl}$ content); (2) mineral-bound waters chemically expelled during clay mineral diagenesis. This is probably the most important source of water in the MV systems. During their burial with gradually rising pressure and temperature, the rocks progressively increase the mineral dehydration process, releasing significant amounts of structural water. These smectite-illite transformations (i.e. illitization) typically start at temperatures around $60{ }^{\circ} \mathrm{C}$ and are nearly completed at $160{ }^{\circ} \mathrm{C}$ and usually occur at depths between $2-5 \mathrm{~km}$. These low salinity fluids are typically characterised by increased values of $\delta^{18} \mathrm{O}, \mathrm{B}$ and Li content and decreased values of $\delta D$ (Dählmann and de Lange, 2003); and (3) shallower meteoric waters, that, in the case of onshore MVs, will result in a decrease in elements as well as a specific isotopic signature that falls along the Global Meteoric Water Line (GMWL). The GMWL plots the equation of the typical relationship between hydrogen and oxygen isotope ratios in natural terrestrial waters, expressed as a worldwide average (Craig, 1961). The composition of the fluids erupted at onshore MVs may be further modified by subaerial surface processes and be, for example, diluted by rain and/or concentrated by evaporation and dissolution of salt crusts typically present around seeping sites. Similarly, depending on the sampling technique used for targeting MVs offshore, the true signature of deep fluids may be modified by significant input of shallow interstitial water or bottom water. 
Indeed every setting presents its own peculiarities. In the subsurface, many factors control the chemistry of formation waters and their mixing and reaction history: These may include: the porosity and the depositional environment of the host formations (e.g. marine, non marine), the temperature and the pressure gradients, the presence of gas hydrates or tectonic structures that control the migration of fluids and trigger different types of mineralogical and geochemical reactions (Carpenter and Miller, 1969; Fournier and Truesdell, 1973; Hanor, 1994; Worden, 1996; Dia et al., 1999; Kopf and Deyhle, 2002; Dählmann and de Lange, 2003). Besides the setting, water composition may also be affected by local tectonics. The combinations are numerous. For example, depending on their location and geological structures, MV feeding systems may intersect brine rich formations, evaporites or salt diapirs (e.g. Jakubov et al., 1971; Lagunova, 1974; Dia et al., 1999; Aliyev et al., 2002; Planke et al., 2003). Passive margins (e.g. Gulf of Mexico) or restricted basins (Palaeo-Tethyss) with a hot (palaeo) climate tend to have buried evaporite deposits or residual brines with high $\mathrm{Cl}$ content. Numerous MVs in these areas, including the Mediterranean, display this typical Clrich signature as brines originating from e.g. the underlying Messinian evaporites emerging to the seafloor (Aloisi et al., 2000; Dählmann and de Lange, 2003; Hensen et al., 2007; Scholz et al., 2009; Haffert et al., 2013). As MVs are often associated with hydrocarbon reservoirs, brines escaping from oilfields may also mix with the fluids rising from greater depth increasing e.g. the $\mathrm{Cl}, \mathrm{B}, \mathrm{Br}, \mathrm{K}$ and Zn content (Collins, 1975; Aliyev et al., 2002; Planke et al., 2003). Alternatively, the presence of neighbouring magmatic volcanic systems or deep sourced hydrothermal fluids may result in waters with signatures showing enrichment in Li and B. Deviating Sr isotope ratios $\left({ }^{87} \mathrm{Sr} /{ }^{86} \mathrm{Sr}\right)$ from seawater are indicative of leaching of sediments or crustal rocks at high temperatures or re-crystallisation of deeply buried carbonates both of which are in agreement with a deep water source(Scholz et al., 2009; Hensen et al., 2015). On the other hand, MV fluids may also be affected by low-temperature weathering of silicate minerals (Aloisi et al., 2004). The targeted study of some elements such as iodide and bromide content may be used to indicate organic matter diagenesis in sediments and rocks (Martin et al., 1993; Dia et al., 1995; Gieskes and Mahn, 2007; Lu et al., 2007; Scholz et al., 2010) since their increase is directly correlated with an increasing intensity of organic matter decomposition.

Previous studies also demonstrated that in subaerial conditions distinct water chemistry is observed depending on the type of seepage locality. The study reported by Mazzini et al (2009b) focused on detailed measurement of the onshore Dashgil MV describing the different 
geochemistry of the three main seep systems: (a) gryphons; (b) pools; and (c) salsa lakes. The results of our broader water collection from several MVs reveal that the conclusions from these authors can be also applied to other structures, and not just to Dashgil MV. The seeping waters show a wide range in solute content.

Our new data from the six MVs in Azerbaijan (Table S1B) show that overall the gryphons expel water with lower $\mathrm{Cl}$ contents in contrast with the water-dominated pools and salsa lakes (the most hypersaline). Trace elements like B and Li are higher in the muddier gryphons and pools compared to in the salsa lakes. Overall, chlorinities are higher than in the Caspian Sea and comparable to the nearby Dashgil and the offshore Guneshli oil fields production waters. Gryphons usually have the most ${ }^{18} \mathrm{O}$ enriched waters while samples with $\delta \mathrm{D}$ lower than $-30 \%$ o are generally from pools. Sampling of the salsa lakes during the fall season show consistently higher $\mathrm{Cl}$ and $\delta^{18} \mathrm{O}$ compared with the winter campaigns, while gryphons do not display a clear seasonal trend. Some general conclusions can be summarised regarding the plumbing system based on water analyses.

\section{Gryphons}

1141 Water from clay dehydration occurring at depth seems to be the main source feeding the gryphons. This is consistent with a) low salinities, b) high $\delta^{18} \mathrm{O}$ values and c) high $\mathrm{Mg} / \mathrm{Ca}$ ratios. This supports the scenario of the expulsion of deep rooted mud breccia clasts often observed at gryphon sites where virtually constant temperature is measured throughout the year. The "contamination" of shallow meteoric fluids appears to be negligible, most likely due to the semi-constant expulsion of overpressured mud from depth.

Salsa lakes

1149 Compared to gryphons, salsa lakes display lower $\mathrm{B}, \mathrm{SO}_{4}$, and $\mathrm{Li}$ suggesting that evaporation 1150 has a stronger control on water geochemistry. A mix of shallow meteoric (predominant) and 1151 deeper (in smaller amount) waters is expected here. The high salinity recorded could be ascribed to the dissolution of halite crusts near the summit and in situ evaporation during the warmer season. 
A remarkable variety in composition is recorded at pool sites. The different rates and vigour characterising the various pools as well as the lower $\delta^{18} \mathrm{O}$ values suggest a strong input of meteoric fluids.

\subsection{Learnings from seasonal sampling and temporal variability}

Seasonal variations in the isotopic composition of rain and snow can periodically alter the water composition of the subaerial seeps resulting in differences in the $\delta^{18} \mathrm{O}$ and $\delta \mathrm{D}$ when comparing summer and winter sampling. For example, during the winter (or during colder and dryer climate) $\delta^{18} \mathrm{O}$ and $\delta \mathrm{D}$ have lower values when plotted along the GMWL and compared with the higher values for the summer (or hotter climate) periods. This difference is typically visible at pools or salsa lake sites that are more affected by meteoric fluids.

Fig.12 D shows the results of the water samples collected in Azerbaijan. Along the GMWL the samples with frozen water sampled at Koturdag and samples of Garadag after a heavy rain are plotted. All the other samples have $\delta^{18} \mathrm{O}$ clustered between 1 and $9 \%$. Interestingly the results also reveal a large spread of results in the isotopic and solute (Table S1B) composition from a single MV. These results highlight that an extensive (i.e. differentiating the type of seeping structure sampled) and seasonal campaign is necessary for broad and solid interpretations. This paradox can be easily observed when comparing these results with a collection of $\delta^{18} \mathrm{O}$ and $\delta \mathrm{D}$ waters from MVs worldwide (see refs in figure). For example the variations in water $\delta^{18} \mathrm{O}-\delta \mathrm{D}$ of Dashgil MV cover a large part of the data from many structures worldwide, emphasising the need for targeted campaigns and careful interpretations. The difficulty in monitoring and sampling MV waters is challenging for offshore structures where the sampling location cannot be as accurate as onshore and therefore seawater contamination/mixing can easily occur.

\section{MV formation dynamics}

\subsection{Gravitative instability, fluid overpressure and hydrofracturing}


As mentioned in Chapter 2, the main engine driving the formation of MVs (i.e. sedimentary volcanism) is generally a combination of gravitative instability of shales and fluid overpressures (e.g. Kopf, 2002; Revil, 2002). Gravitative instability is due to the overall low density of clay-bearing strata that can be buoyant in the surrounding units. This is generally due to rapid sedimentation rates in subsiding basins. Such instability is a prerequisite for MV initiation: the shale can start uprising (mobilised shale) autonomously by buoyancy (shale diapirism), often supported by hydrofracturing (Revil, 2002), combined with fluid overpressures that can accelerate and sustain the motion of fluid-rich sediments (mud and rock fragments) up to the surface.

Fluid overpressures can develop in the same "instable" (mobile) shale or in surrounding sedimentary rocks, other shales, reservoir rocks or fractures. Overpressure in shales may be due to volumetric expansion due to generation of hydrocarbons from kerogens, or additional cracking of heavy hydrocarbons into lighter ones. Additional mechanisms may include the thermal effect in pore fluids as temperature gradient increases, dehydration reactions (e.g. volume increase by opal A/CT quartz, or illitization of clay minerals) and to disequilibrium compaction (Revil, 2002), i.e. imbalance between pressure build-up due to lithostatic loading or compressive tectonic stresses and pressure dissipation by fluid flow. Indeed, mechanical compaction during gradual burial or sudden events (slides, slumps, thick turbidite deposits) increases intragranular overpressure. At locations with high rates of basin sedimentation and/or subsidence, a large amount of seawater is trapped in the intergranular spaces inducing exponentially higher overpressure during the burial of the undercompacted units.

If the mobilised shale, ascending by buoyancy, meets pressurised fluids in reservoirs and fractures, its motion upwards can be accelerated and sustained up to the Earth's surface. Input of allochtonous fluids, external to the sedimentary system, such as deeper geothermal or volcanic fluids, may also contribute to overpressure build-up. In submarine environments, dissociation of gas hydrates can also induce gas liberation and pressure increases.

In any case, overpressured sediments must be initially isolated by impermeable barriers (i.e., must be pressurised compartments). Hydrofracturing, i.e. the opening of the impermeable barriers, allows for the pressurised gas-water-sediment motion towards the surface and the brecciation of sedimentary units. Hydrofracturing can be just due to the increase of fluid pressure creating fractures, which may connect the pressurised fluid system to pre-existing permeable pathways (faults). Fracturing may also be due to tectonic stresses, fault reactivation and seismicity as described below. 
In practice, the MV formation should foresee the following processes (also depicted in Fig. 13):

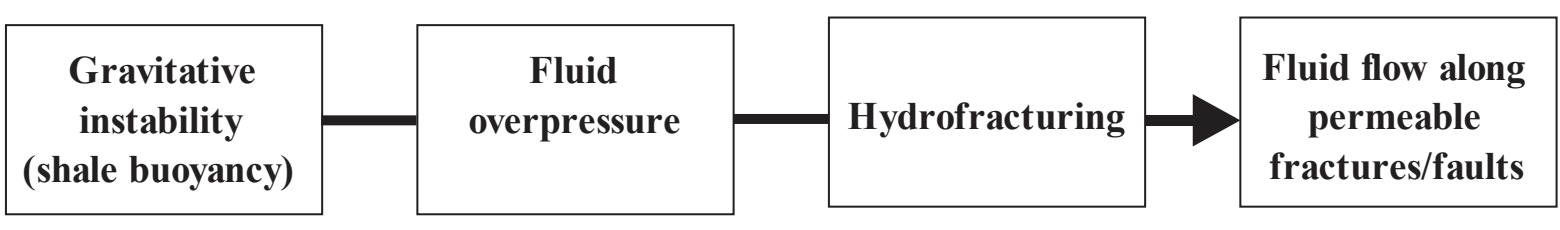

This combination of factors must be seen as a specific petroleum seepage system, according to the definition of Abrams (2005).

The final stage of MV growth is its manifestation to the surface. This may happen in a gradual manner with progressive and slow release of mud and fluids, or in violent and parossistic forms (eruption). In the second case, a MV birth scenario envisages that when overburden weight is not sufficient to contrast the pressure of the migrating fluids and the growth of the piercement towards the surface, a critical depth is reached. At this threshold depth fracturing and breaching of the uppermost units occur, sometimes facilitated by external factors (e.g. earthquakes). Solid earth tides have also been proposed as a mechanism to influence eruptions and geological phenomena such as seismic activity (Guliyev and Feizullayev, 1997; Tanaka et al., 2004; Métivier et al., 2009).

Another peculiarity of MVism is the transport to the surface of breccia, defined in Section 2.2. The brecciated sediments present throughout the feeder channel have a reduced cohesion. As the breaching to the surface occurs, the accumulated pressure suddenly drops and the low cohesion media are easily fluidised and ultimately vacuumed to the surface. It is well known that some of the clasts erupted at MV sites originate from several kilometres in depth (i.e. some Caspian MVs have roots as deep as $15 \mathrm{~km}$ ) and that they can reach the size of some meters. Is it likely that during the eruptions, MVs have an open conduit of several kilometres?

The mechanisms described above do not necessarily imply significant subsurface movements of the brecciated sediments prior to the eruption, nor during the growth of the emerging diapir. One possible scenario is that the large clasts reach the surface after several eruptive cycles. In other words each eruption contributes to the rise of the oldest sediments. We envisage that the youngest eruptions have a larger amount of old rocks. 
1255 Few attempts have been made to model the dynamics of piercement structures and MVism 1256 (e.g. Gisler, 2009 and references therein; Zoporowski and Miller, 2009). Mazzini (2009) 1257 suggested a simple scenario describing the birth of a MV beginning from the initial growth at 1258 its roots where an initial fluid overpressure is present. Revil (2002) stressed the importance of 1259 hydrofracturing and hydro-mechanical non-linear shock waves. Nermoen et al. (2010) attempted some sand box experiments to investigate the processes controlling the fluidisation prior to the eruption. Conversely Lance et al. (1998) and Murton and Biggs (2003) completed some analogue experiments and numerical modelling to understand the morphology of some offshore MVs based on expelled mud rheology and isostatic parameters. In any case, all models are limited in dimension and resolution, and require much better constraints on the parameters of the erupting systems. For example modelling attempts to predict the longevity and behaviour of mud eruptive systems have been shown to be incorrect demonstrating that the processes in the region of diffused upwelling are poorly understood (Davies et al., 2011; Rudolph et al., 2011). Therefore there is the absolute need to use models based on direct field observations and tight constraints.

1270 Exploratory efforts are continuing to probe the development of morphologies and phenomenologies and how they depend on the rheology of the erupted fluids and that of the country rocks, and on the depth, nature, and overpressure of the source material. Indeed, there are important parameters that are crucial to model clastic eruptions and could be tentatively divided in two main groups: internal and external parameters. The first group can include the geometry of the feeder zone that may consist of intricate networks or single or multiple pipeshaped conduits crossing one or several stacked reservoirs. In addition, deformations including volumetric contractions (or "peristalsis") of the conduit during the eruption and the coupling between volumetric contractions and fluid flow may occur. Key parameters to be considered for modelling are chemical and multiphase reactions and multiphase flows. For example, the interaction between fluids with different chemical and isotopic composition, and the properties of the erupted mud (e.g. density, viscosity), including changes in the density of rising fluids in response to changing pressure and temperature. External parameters that may alter the piercement behaviour may include seismic events. These can periodically alter the critical equilibrium of the MVs inducing fluidisation, opening new fractures or allowing influx of deeper and/or hotter fluids. External fluids emitted in the system may generate additional overpressures as well as trigger e.g. higher temperature reactions with the organic 
matter present in the sediments producing new gas or altering the mineralogy of the sediments.

\subsection{MVs and seismicity}

It is well known that gas migration, seepage and, in particular, eruptions of MVs, can be stimulated by earthquakes, i.e. by the passage of seismic waves or by co-post-seismic changes in crustal stress and permeability (e.g. Chigira and Tanaka, 1997; Guliev and Feizullayev, 1997; Linde and Sacks, 1998; Delisle et al., 2002a; Kopf, 2002; Hieke, 2004; Nakamukae et al., 2004; Manga and Brodsky, 2006; Ellouz-Zimmermann et al., 2007; Lemarchand and Grasso, 2007; Mau et al., 2007; Mellors et al., 2007; Walter and Amelung, 2007; Judd and Hovland, 2007 ; Eggert and Walter, 2008; Mazzini et al., 2009a; Lupi et al., 2014; Bonini et al., 2016). Many MVs and piercement systems erupted within a few days or months after earthquakes (e.g. Abikh, 1939; Chigira and Tanaka, 1997; Guliyev and Feizullayev, 1997; Aliyev, 2004; Miller et al., 2004; Baciu and Etiope, 2005; Martinelli and Dadomo, 2005; Mellors et al., 2007 and references therein; Manga et al., 2009; Madonia et al., 2011), but it is sometimes difficult to distinguish a true seismic trigger from a mere coincidence. While reports of correlations between earthquakes and MV eruptions are widespread, little is known about the processes triggered by passing seismic waves and whether delayed triggering is possible.

Manga et al. (2009) suggest a relationship between earthquake magnitude and the distance over which a variety of responses can be documented, such as increases of stream flows, liquefaction effects, changes in geysering activity, alterations at magmatic and mud volcanoes. Based on their plot, the authors propose a threshold (combining magnitude and hypocentral distance) for triggering responses in the above systems. For example they suggest that MV activity can be triggered by a seismic event with magnitude 5 if it happens within a distance of $20 \mathrm{~km}$; hundreds of $\mathrm{km}$ are sufficient for earthquakes with $\mathrm{M}>7$. Nevertheless this threshold could be subject to modifications. For example, the Manga et al. (2009) plot shows outliers for liquefaction examples and MVs events. Delle Donne et al. (2010) provide a similar type of plot reporting measured data on liquefaction effects and responses observed in magmatic volcanoes. The authors provide examples highlighting that all these systems are sensitive to even further and less powerful events (i.e. M 5.5 at more than $200 \mathrm{~km}$ and $\mathrm{M}>7$ at $\sim 1500 \mathrm{~km})$. Ultimately additional occurrences could be included in 
the plots that, once again, indicate that these types of piercements may be sensitive to events occurring even thousands of kilometres away from the epicentre (Brodsky et al., 2003; West et al., 2005; Sil and Freymueller, 2006; Farías et al., 2014). Among the remarkable instances we cite: the changes in Yellowstone geysers eruption behaviour after the 2002 M 7.9 Alaskan Denali earthquake (Husen et al., 2004); the alterations recorded at the Salse di Nirano MV after the June 2013 M 4.7 event occurring $60 \mathrm{~km}$ away (Lupi et al., 2016); the sudden eruption of Napag MV (Fig. 4B, Fig. 5G) triggered just after the 2003 M 6.6 Bam earthquake (distance of $\sim 430 \mathrm{~km}$ ) (Dang_news, 2016); the eruption of a new MV in Pingtung after the 2016 M 5.5 earthquake occurring in Taiwan nearly $250 \mathrm{~km}$ away (O'Neill, 2016); the enhanced venting reported by locals at the Kalang Anyar, Gunung Anyar, and Polungan MVs located $\sim 270 \mathrm{~km}$ away from the 2006 M 6.3 Yogyakarta earthquake (Mazzini et al., 2009a); the formation of the MV island offshore Gwadar (Pakistan) few hours after the September 2013 M 7.7 earthquake occurring $410 \mathrm{~km}$ far from the coast (Avouac et al., 2014). As a side comment, it is interesting to remark the last peculiar case of dynamic triggering. On the 16.04.2013 a Mw 7.8 dip-slip earthquake occurred $315 \mathrm{~km}$ away from Gwadar without triggering any response. However, five months later (i.e. on the 24.09.2013) a $\mathrm{Mw} 7.7$ strikeslip earthquake occurred further than the previous event (i.e. $410 \mathrm{~km}$ ) triggering the eruption of the new mud island (Fig. 14B). One of the reasons underlining the trigger-non trigger occurrence may be related to the difference between the amount of S-waves generated by dip slip and strike slip earthquakes. For instance, Lupi et al., (2013) show that hydrothermal systems in a critical state are more sensitive to $\mathrm{S}$ waves than $\mathrm{P}$ waves. Dip-slip and strike slip earthquakes impose a different directivity of shear-wave radiation with strike slip earthquakes projecting more shear horizontal waves parallel to the earth surface in both body and surface waves.

These observations highlight that more research is needed in this field and that it is arduous and may be misleading to trace schematic thresholds, especially considering that it is difficult to estimate how critically stressed each system is in a given moment. In this respect, the MV eruptions cited above are consistent with the empirical threshold line indicated by Delle

1349 Donne et al. (2010) rather than the Manga et al. (2009) that does not seem to be appropriate 1350 (Fig. 14A).

1351 Despite the many incertitudes, it is clear that seismicity affects shale liquefaction, fluidisation 1352 and loss of strength, fracture opening, increased hydraulic permeability, removing of 1353 hydraulic barriers, and bubble nucleation and growth are possible specific mechanisms of 
eruption triggering. Obviously reactivated faults represent an ideal pathway to release fluids from greater depth. Laboratory experiments showed that strike-slip movement (shearing) is an efficient mechanism (Mazzini et al., 2009a). Strike-slip faulting can significantly reduce the critical fluid pressure, in turn inducing sediment deformation and fluidisation. Given a fluid overpressure at depth, localisation of tectonic stresses may induce fluidisation in situation that would otherwise be stable.

\section{Implications}

\subsection{Hydrocarbon exploration}

MVs, other hydrocarbon seeps and buried piercement structures, are common in many petroleum provinces worldwide and represent ideal targets for hydrocarbon exploration. The largest seepage and MV provinces are also among the major hydrocarbon exploration and production regions (e.g., the North Sea, the Caspian Sea, the Gulf of Mexico, the Black Sea, the Sea of Okhotsk, the Sea of Japan). Many large onshore hydrocarbon fields were discovered after drilling around MVs in Europe, the Caspian basin, Asia and the Caribbean (Ansted, 1866; Ciocardel, 1949; Link, 1952; Martinis, 1962; Jakubov et al., 1971; Shnyukov et al., 1986; Rhakmanov, 1987; Guliyev and Feizullayev, 1997; Etiope et al., 2009b). At these localities reservoirs are staked at multiple levels through the feeder zone. These structures have been intensively studied by academia and the oil industry as they represent an open window of deep seated plumbing systems. These natural boreholes can provide relevant information regarding the nature and the processes involving hydrocarbon systems. In particular, in Azerbaijan, Jakubov et al. (1971) documented the intimate relationship between MVs, petroleum reservoirs, and structural traps (e.g. anticlines). The feeder channels for the MVs, normally rooted below the reservoir levels (commonly at 1-3 km depth), act as pathways for fluids during the eruptions and possibly during the dormant stage (Planke et al., 2003). The processes at various levels of the MVs, i.e. roots, reservoir, and shallow system, still remain poorly understood.

Knowing the molecular and isotopic composition of the gas released by MVs (see Section 4.2) allows the assessment of origin and quality of the hydrocarbons stored in the reservoirs. For example, MV gas analyses may help to discriminate shallow microbial gas from deeper 
thermogenic accumulations, and may suggest the presence of oil and undesirable nonhydrocarbon gases, such as $\mathrm{CO}_{2}, \mathrm{~N}_{2}$ and $\mathrm{H}_{2} \mathrm{~S}$. MV gas can also indicate subsurface petroleum biodegradation, which has an important impact on hydrocarbon quality and may influence exploration and production strategies. Thus, MV gas geochemistry can contribute to assessing, prior to or without drilling, a petroleum system, which is particularly useful in

1392 frontier or partly unexplored areas.

1393 Finally, while it is clear that petroleum extraction from reservoirs may affect the activity of MVs nearby, due to the lowering of the fluid pressures (Etiope, 2015), the impact of MV activity into petroleum production is poorly known. The geodynamic relationship between reservoirs and MVs behaviour remains unclear also due to the limited data available. Some conclusions can be inferred from the frequent erupting MVs, such as Lokbatan. For example after the 2001 and 2010 Lokbatan eruptions (I. Gulyev pers. comm.), the oil production from the numerous wells located all over the MV remained essentially unaltered. This implies that the two systems are either not connected or that during the eruption deeper seated mechanisms are predominant. One hypothesis is that during the eruptions, the flanks of the MV feeder channel is sealed by the rising fluids, therefore compartmentalising and not affecting the conditions of the reservoirs intersecting the conduit or the region of diffused upwelling. Since in some instances a production increase from some wells has been even recorded, we suggest that the overpressure increase inside the feeder zone may also affect the external zone hydraulically connected to the productive reservoirs.

1407

\subsection{Geohazards}

1409

1410 Geohazards are geological situations and/or features that can present critical conditions 1411 resulting in damage or risk. Although MVs are ideal targets for hydrocarbon exploration, they 1412 do represent geohazards for the following reasons:

1413 a) the potentially violent release of large amounts of hydrocarbons and mud

1414 b) the degradation of soil (or sediments at seafloor) and quicksand effect

1415 c) episodic dissociation of submarine gas hydrates.

1417 a) Explosive eruptions of self-igniting methane are not unusual either onshore or offshore 1418 (Bagirov et al., 1996; Aliyev et al., 2002). This phenomenon is probably related to the high 1419 velocity of the vented gas that may reach supersonic speed and thus self-combust causing 1420 spectacular fiery eruptions. The $6^{\text {th }}$ of February 2017 eruption of Otman Bozdag MV in 
1421 Gobustan (Azerbaijan) is the most recent example of such type of event. In 2014 a tragedy occurred in Italy when two children, 7 and 9 years old, died in a sudden eruption of mud in the Maccalube MV in Sicily. The children were walking along a path open to the public, close to a quiescent crater that suddenly erupted producing a mud column several meters high. The Piparo MV in Trinidad erupted in February 1997 with mud ejections $50 \mathrm{~m}$ high. Residents of the nearby village managed to escape rapidly from their houses before mud spilled into the village crushing roofs.

b) Many MVs have craters and muddy pools that represent a potential threat. Small MVs, such as those occurring in northern and central Italy, which are easily accessible a few meters from busy main roads (e.g., Pineto in the Abruzzi Region or Ospitaletto in Emilia Romagna) have craters less than $1 \mathrm{~m}$ wide, but the fluid mud is more than 2-3 $\mathrm{m}$ deep and can be a lethal trap. MVs can also perturb soil foundations and urban facilities (Etiope, 2015).

It is not uncommon to find numerous settlements around or even on the crater zone (!) of MVs. Among the numerous examples we can cite Liyushan (Taiwan), Piparo (Trinidad), Kalang Anyar, Gunung Anyar, Pulungan (Indonesia), Gobu (Azerbaijan), Serra de Conti, Santa Barbara, Salinella Stadio di Paternò (Italy).

Large areas covered by thick erupted mud breccia flows, pose severe geohazards in case if liquefaction following on from e.g. seismic activity.

c) Offshore MVs are frequently associated with provinces of gas hydrate deposits (e.g. Tinivella and Giustianiani, 2012). As these buried methane reserves are likely to be exploited in the future, an improved understanding of MVs and buried piercement structures is relevant for the petroleum industry to reduce the potential hazard posed for drilling and platform construction, and pipeline routings. Sidewall slumping at onshore and offshore MVs is a common phenomenon that should be considered for production installations. Indeed inflation and deflation mechanisms constantly occur at active MVs.

\subsection{Methane emission to the atmosphere}

MVs are one of the five categories (including gas-oil seeps, microseepage, submarine seepage and geothermal-volcanic manifestations) of geological sources of methane that are currently considered a major contributor for the atmospheric methane budget (Etiope and 
1455 Klusman, 2002; Ciais et al., 2013; Etiope, 2015). In total geological sources release about 60

1456 Mton $\mathrm{CH}_{4}$ per year, of which onshore MVs contribute for about 25-30\% (Etiope, 2015).

1457 Geological emissions are the second most important natural source of methane after 1458 wetlands, and account for about $10 \%$ of total methane emissions from anthropogenic and 1459 natural sources (Ciais et al., 2013).

1460 As for the other geological emission categories, global methane emission estimates from 1461 MVs have been derived using the same procedures adopted for natural and anthropogenic gas 1462 sources, as recommended by the air pollutant emission guidebook of the European 1463 Environment Agency (see Etiope, 2015 and refs. therein). The procedures are based on the 1464 distinction between "point sources" and "area sources", and on the concepts of " activity" and 1465 "emission factor". In the case of MVs, a "point source" refers to macro-seeps or vents (see 1466 Section 3) with a flux expressed in kg/day or tonnes/year. An "area source" is the diffuse 1467 seepage (i.e., miniseepage, as described in Section 3.7) with a flux generally expressed in mg $1468 \mathrm{~m}^{-2}$ day $\left.^{-1}\right)$. "Activity" is practically the number of focused vents or the area of diffuse 1469 degassing. Each MV includes point sources, vents, bubbling pools, and an area source, the miniseepage. Therefore the total gas emission from a MV is the sum of all of the point sources plus total outputs from the invisible diffuse miniseepage surrounding the vents. The "emission factor" is the total emission divided by the area of the seepage (areal emission factor: $\mathrm{kg} \mathrm{m}^{-2}$ day $^{-1}$ ). For MVs, the "emission factor" incorporates emissions from vents and miniseepage, and can also be expressed in terms of a "point emission factor" $\left(\mathrm{kg} \mathrm{day}^{-1}\right)$. In this case, "activity" corresponds to the number of emission points. In practice, the global methane emission from a MV can be estimated by multiplying the areal emission factor by the global area formed by all MVs (for example, as estimated by Etiope and Milkov, 2004), or by multiplying the point emission factor by the global number of MVs. Emission factors of MVs have been assessed on the basis of hundreds of direct flux measurements in the field, in Italy, Romania, Azerbaijan, Japan and Taiwan (see Etiope, 2015 and refs. therein). The single vents or craters of small MVs (e.g. 1-5 m high) can release up to tens of tonnes of methane per year. An entire MV (hosting tens or hundreds of vents) can continuously emit hundreds of tonnes of $\mathrm{CH}_{4}$ per year, and eruptions from MVs can release thousands of tonnes of $\mathrm{CH}_{4}$ within a few hours. However, only very approximate and indirect estimates are available for gas outputs during eruptions (e.g. Guliyev and Feizullayev, 1997).

1487 Estimates of the $\mathrm{CH}_{4}$ measured flux at $\mathrm{MV}$ areas during their dormancy periods (i.e. from 1488 seeps, gryphons and miniseepage), vary between 100 and 10,000 tonnes $\mathrm{km}^{-2}$ year $^{-1}$, with a 
global average of 3,150 tonnes $\mathrm{km}^{-2}$ year ${ }^{-1}$. Global $\mathrm{CH}_{4}$ emission estimates published in the literature range from 5 to 20 Mton/y (Dimitrov, 2002; Etiope and Klusman, 2002; Etiope and Milkov, 2004; Etiope et al., 2011b). These estimates increased over time as a result of new experimental flux data that include both focused venting and diffuse miniseepage. The latest estimates (20 Mton/y) were also based on classifications of MV sizes in terms of area, following a compilation of data from $120 \mathrm{MVs}$ and updated emission factors (Etiope et al., 2011b). The largest uncertainty is related to emissions during eruptions, for which there are not direct flux measurements, yet.

\section{A leading case-study: the Caspian Basin mud volcanism}

The South Caspian Basin is a Tertiary back-arc basin with an up to $25-30 \mathrm{~km}$ thick sedimentary package making it one of the deepest basins in the world (see Planke et al., 2003 and refs therein). Sedimentation rates during the Quaternary, as high as $2.4 \mathrm{~km} / \mathrm{Ma}$ deposited 5-8 $\mathrm{km}$ of sediments during the last 5 million years. Due to the local low geothermal gradients $\left(10-18^{\circ} \mathrm{C} / \mathrm{km}\right)$ immature source rocks for oil generation can be present down to great depths (up to $14 \mathrm{~km}$ according to Abrams and Narimanov, 1997; and Nadirov et al., 1997).

Today the Caspian Basin is one of the richest oil and gas provinces and represents one of the regions with the highest abundance and variety of continental and offshore MVs broadly distributed onshore in the Gobustan area (eastern Azerbaijan), the Apsheron Peninsula, throughout the Southern Caspian Basin and, on the eastern size of the Caspian, in Turkmenistan overlying the faulted and hydrocarbon-bearing anticlines (Jakubov et al., 1971). This is related to three main factors: 1) rapid Quaternary infill of one of the world's deepest sedimentary basins, 2) the rapid Miocene-Pliocene sedimentation and burial lead to increased maturation of organic material, diffuse methane generation in deeply buried clay units, and 3) compressional tectonics leading to anticline traps, and frequent seismicity that possibly triggers eruptions (Inan et al., 1997; Nadirov et al., 1997; Guliyev et al., 2004; Mellors et al., 2007). Due to this rapid basin subsidence, and the basin infill, the natural sediments dewatering did not cope with the high sedimentation rate. Lithostatic load transferred to pore water pressure resulted in overpressured units. The pressure and gravity disequilibrium of these under-compacted shales made them buoyant due to low viscosity and plasticity. In this thick and under-compacted basin, hydrocarbon generation and maturation is 
still ongoing, particularly in the deeply buried $(8.5-11 \mathrm{~km})$ Maikop Formation (Fowler et al., 2000).

Mud breccia studies highlighted that numerous MVs in the Gobustan area of Azerbaijan are rooted at least within the Oligocene-Miocene section of the organic-rich Maikop Formation (and perhaps deeper?). This formation, typically 1-2 km thick, is considered as the main source of both the extruded mud and the petroleum and is located between $8.5-$ and $11-\mathrm{km}$ depth offshore Baku, and at 5.5-km depth underneath the offshore Shah Deniz structure (Inan et al., 1997; Fowler et al., 2000). Clasts and sediments from deeper formations suggest that in some cases the source could be as deep as $14 \mathrm{~km}$ (Inan et al., 1997; Cooper, 2001).

More than 400 active MVs were considered to exist in this region (Jakubov et al., 1971; Aliyev et al., 2002), of which numerous are located offshore; about 180 MVs are however documented onshore in Azerbaijan (Etiope, 2015). Almost 300 historic small and large MV eruptions are then documented (Aliyev et al., 2002).

The Caspian Sea is exceptionally rich in hydrocarbon fields in particular in the southern part that also contains the highest density of MVs. The $75 \%$ of these structures is located at the top of anticlinals or coinciding with faults that in some instances are detached at the basement level (Ginsburg and Soloviev, 1994; Dadashev et al., 1995; Corthay and Aliev, 2000; Yusifov and Rabinowitz, 2004). Others are positioned on the flanks of folds. Based on acoustic data, Huseynov and Guliyev (2004) concluded that the shape of the offshore MVs in the Caspian Sea varies from convex, concave, flat or buried. MVs with low relief (several tens of meters) are concentrated primarily in the north-eastern portion of the south Caspian Basin; MVs with large vertical relief (greater than $200 \mathrm{~m}$ ) are clustered in the southwest part of the basin.

\section{Emerging issues and future research}

\subsection{Mud volcanism on other planets}

The phenomenon of MVism was suggested for other planets in the solar system (Bradak and Kereszturi, 2003; Fortes and Grindrod, 2006) and in particular for Mars (e.g. Tanaka et al., 2003; Skinner and Mazzini, 2009; Oehler and Allen, 2010; Etiope et al., 2011c).

On Titan, a Saturn's moon, theoretical studies addressed the possibility of sedimentary volcanism associated to fluid and solid phases that, however, may be chemically and 
physically different from the terrestrial ones: for example liquid hydrocarbons and "mud" composed by light acetylene-rich sediments, whose upward migration may be triggered by density inversion due to overlaying layers of pure ice (Fortes and Grindrod, 2006). Radar images acquired by the Huygens-Cassini probe suggested the presence of subcircular structures that have been interpreted as potential MV edifices (Fortes and Grindrod, 2006). On Mars, several studies reviewed the possible regions where martian sedimentary basins might fulfil the requirements for MVism and where satellite surveys reveal images similar to those observed in MV provinces on Earth. Possible MVs have been reported from Utopia, Isidis, Scandia, Chryse Planitia, Acidalia Planitia, Valles Marineris and Arabia Terra (Davis and Tanaka, 1995; Tanaka, 1997; Tanaka et al., 2000; Tanaka et al., 2003; Farrand et al., 2005; Tanaka, 2005; Kite et al., 2007; Rodriguez et al., 2007; Skinner and Tanaka, 2007; Tanaka et al., 2008; Allen et al., 2009; McGowan, 2009; Oehler and Allen, 2009; Skinner and Mazzini, 2009; McGowan and McGill, 2010; Oehler and Allen, 2010; Pondrelli et al., 2011; Ivanov et al., 2014; Komatsu et al., 2016; Okubo, 2016). Acidalia Planitia is the martian region with the highest number of mounds resembling terrestrial MVs, with estimated $>40,000$ structures of which 18,000 have been mapped (Oehler and Allen, 2010; Etiope et al., 2011c).

Overall, the satellite images collected from the martian surface provide convincing evidence of the geomorphological resemblance with the MV features observed on Earth. Nevertheless, so far, there is no possibility to prove that one of the main forces activating these extra-terrestrial phenomena is the same as described for MVs on Earth (i.e., the presence of overpressured gas and mobilised shales). The variable detection of methane in the martian atmosphere, coupled with its relatively short lifetime (Mumma et al., 2009 and Refs. therein) should imply the presence of active seepage, i.e. gas emission structures in the martian subsoil. MVs may represent, then, one of these methane emitting structures. Martian MVs should be candidate landing sites in future exploration missions (as suggested by Skinner and Mazzini, 2009; and by Etiope et al., 2011c), as they represent natural windows into underground sedimentary rocks and environments which may reveal precious information about potential occurrence of methane and deep biosphere life.

\subsection{Seepage and microbial activity}


Extensive research has been conducted to study the activity of microbial colonies thriving offshore at MV (or pockmarks) sites where the diffuse methane seepage is common. Sediment microbial communities may vary with differing gas seep regimes or with a temporary halt in the gas release (e.g. Coelho et al., 2016 and refs therein). Offshore methane seepage is typically coupled to anaerobic methane oxidation operated by microbial colonies of archea and bacteria. This reaction releases $\mathrm{C}$ ions that bind with $\mathrm{Ca}$ present in the seawater, ultimately resulting in authigenic carbonates precipitation (Valentine and Reeburgh, 2000; Boetius and Suess, 2004; Boetius and Wenzhöfer, 2013). Methanogenic carbonates are indeed common features at many pockmarks and MV sites (Kocherla et al.; Magalhães et al.; Hovland et al., 1987; Naehr et al., 2000; Greinert et al., 2001; Gontharet et al., 2007; Akhmetzhanov et al., 2008; Greinert et al., 2010; Haas et al., 2010). For example, spectacular and remarkably thick microbial mats colonies were observed growing inside the carbonates of Dolgovskoy Mound and Odessa MV, or at $\mathrm{CH}_{4}$ venting sites in the North-western Black Sea shelf (Michaelis et al., 2002; Mazzini et al., 2004; Mazzini et al., 2008; Bahr et al., 2009). Microbial colonies (Fig. 15) thriving in and around onshore fluid seepage sites are also a frequent phenomenon. These colonies commonly grow around the edge of the pools or frame the gryphon's craters where the water is less muddy and tends to stagnate as the bubbling of the seeping gas does not create turbulence. The most impressive colonies were observed during our 2006 fieldwork inside the Dashgil MV salsa lakes where mats can reach a thickness of $15-20 \mathrm{~cm}$ on embayments at the edge of the salsa lakes. The pigments of the microbial communities vary from brownish to pinkish and greenish colour. In numerous instances, a foamy film was observed, containing numerous micro bubbles floating on the surfaces of the seeps. This suggests that the production of oxygen is currently ongoing and that photosynthesis is likely to be present at sites where green coloured colonies are thriving. Despite the essentially ubiquitous distribution of such colonies at onshore MV sites, very little is known about the microbial processes driving their growth and, to our knowledge, no systematic studies about methanogens and methanotrophs have yet been completed. A first step to initiate the study of this onshore phenomenon has been done by a few authors that also completed some challenging investigations about colonies growing in the subsurface (Yakimov et al., 2002; Alain et al., 2006; Heller et al., 2011; Cheng et al., 2012; GreenSaxena et al., 2012; Heller et al., 2012; Sun et al., 2012; Wrede et al., 2012; Kokoschka et al., 2015). However, the existence of diffuse seepage throughout the muddy cover of onshore MVs (e.g. Hong et al., 2013) suggests that microbial methane consumption is not pervasive and could only be significant in focused, localised zones. 


\section{Sediment-hosted geothermal systems}

Some fluid-mud emission manifestations, apparently resembling MVs, are in reality not driven by sedimentary volcanism, and accordingly, as discussed in Section 2, they should not be considered MVs. It is the case of hybrid systems where magmatic or hydrothermal $\mathrm{CO}_{2}$ rich and vapour-rich fluids, related to igneous intrusions and high temperature geothermal fluids, cross organic-rich and $\mathrm{CH}_{4}$-rich sedimentary rocks, producing at the surface complex gas and mud mixtures of different origins. These hybrid systems may be grouped under the name of "sediment-hosted geothermal systems" (SHGS). The term "sediment-hosted hydrothermal system" (SHHS) may also be used to define systems that are a subset of the "geothermal" family. In fact, not all the geothermal systems, including those in sedimentary basins, present hydrothermal "hot water" circulation (Jackson, 1997). Some basins may host hot dry rock systems or $\mathrm{CO}_{2}$-rich gas-phase systems as those described in e.g. Ciotoli et al. 1642 (2016).

1643 The main SHGS examples are those of the Salton Sea geothermal field in California (e.g. 1644 Helgeson, 1968; Svensen et al., 2009a; Mazzini et al., 2011), the Guaymas Basin rift zone in 1645 the Pacific (Welhan and Lupton, 1987), the LUSI mud eruption in Indonesia (Mazzini et al., 1646 2012), the aligned eruptions in central Java (Mazzini et al., 2014), the Tiber-Delta gas system near Rome (Ciotoli et al., 2016), and the areas with large igneous intrusions such as in the Northeast Atlantic, in South Africa and Australia (Jamtveit et al., 2004; Holford et al., 2013).

1649 SHGSs are typically dominated by geothermal $\mathrm{CO}_{2}$ (from thermometamorphism of 1650 carbonates or magma-mantle degassing) with concentrations typically exceeding 90 vol.\%, 1651 but associated to variable $\mathrm{CH}_{4}$ amounts that are generally higher (orders of 1-5 vol.\%; 1652 Mazzini et al., 2011; Ciotoli et al., 2016) than those of pure volcanic-geothermal fluids 1653 (typically in the order of ppmv and, where some organic-rich rocks are involved, up to 0.1$1654 \quad 0.5-1$ vol.\%). The methane of SHGS is generally thermogenic, from deep source rocks and reservoirs overlying the $\mathrm{CO}_{2}$-rich geothermal circulation system. 
1656 Gas in SHGS can be of considerable interest for petroleum exploration and global climate change studies, because (1) it may be the result of enhanced thermal maturity of sedimentary source rocks, (2) it can be a significant natural source of greenhouse gases $\left(\mathrm{CO}_{2}\right.$ and $\left.\mathrm{CH}_{4}\right)$ for the atmosphere (Etiope, 2015) and (3) a potential driver of past climate changes (Svensen et al., 2004; Svensen et al., 2007; Svensen et al., 2009b; Iyer et al., 2013). However, pure MVs and SHGSs may share many similarities regarding the surface manifestations, notoriously the powerful eruptions of brecciated sedimentary units and the formations of pools or gryphons in the crater zone. For these reasons SHGS are often confused with MVs (e.g., Salton Sea, and several Javanese mud eruptions) although their origin, mechanisms and reactions are different. The most striking example of misattribution of the term "MV" is that of the Lusi mud eruption in Java. Geological and geochemical investigations have in fact shown that this spectacular clastic-dominated geysering system is driven by $\mathrm{CO}_{2}$ and vapour rich hot fluids connected to the igneous and hydrothermal system of the adjacent Arjuno-Welirang volcanic complex (Mazzini et al., 2012).

\section{Conclusions}

This work provides an updated overview of the meaning and implications of mud volcanoes, based on a wide selection of recent literature and field observations, complemented with unpublished data that we acquired during the last 15 years. We emphasise the importance of the terminology for proper attribution of the term "mud volcano" (not all gas-water manifestations releasing mud are mud volcanoes), and the relevance of different processes and structures. The main points are summarised as follows:

(1) Mud volcanoes are broadly distributed throughout the globe in active margins, compressional zones of accretionary complexes, thrust and overthrust belts, passive margins, deep sedimentary basins related to active plate boundaries, as well as delta regions.

(2) They are specifically located in petroliferous basins, along anticline axes, strike slips and normal faults, and fault-related folds.

(3) They represent a specific category of natural gas/oil seepage manifestation (they may belong to a Petroleum Seepage System), often related to deep and pressurised hydrocarbon reservoirs; therefore, they are ideal targets for hydrocarbon exploration as they may confirm the existence of relevant subsurface reservoirs. 
1689 (4) The total number of mud volcanoes on Earth is still uncertain: about 900 structures on 1690 land were suggested in past literature; more than 600 main onshore structures, with a large 1691 variety in shapes and sizes, are specifically documented and listed in recent global datasets. 1692 Several thousand may occur in the deep oceans.

1693 (5) The main engine driving mud volcanism is given by a combination of gravitative 1694 instability of shales and fluid overpressure build-up, in shales, reservoir rocks or fractures, 1695 followed by hydrofracturing of impermeable barriers.

1696 (6) Hydrocarbons are generally of thermogenic origin, while microbial gas is released only in 1697 a few cases.

1698 (7) Fluids and solids are commonly seeping in craters during the dormant stages forming 1699 structures such as pool, gryphons and salsas. Mud often derives from mobilised shales (not 1700 necessarily related to hydrocarbon source rocks); water may derive from very deep sources, 1701 or from reservoir connate waters, or from illitization in shales, sometimes mixed with 1702 meteoric water. The petrographic study of the clasts present in the mud breccia provides a 1703 simple tool to reconstruct the full stratigraphy at depth.

1704 (8) Onshore mud volcanoes are an important source of greenhouse gas (methane) for the atmosphere, releasing globally up to 20 ton $\mathrm{CH}_{4} /$ year. The gas is not only emitted by central craters or visible manifestations, but also from diffuse invisible exhalation throughout the muddy cover.

1708 (9) Mud volcano geometries are highly variable, and depend on the fluid rheology and eruption processes and subsequent erosion.

1710 (10) Seismic data provide important information of the large-scale and deep anatomy of the structures. They show, for example, that piercing structures can play an efficient role in hydrocarbon trap formation (i.e. lateral seals).

1713 (11) Mud volcanism on other planets (e.g. Mars and Titan), and microbial activity associated 1714 to gas seepage represent emerging issues and opportunities for future research.

\section{Acknowledgements}

1718 Field and theoretical work discussed in this paper benefitted of funding from several 1719 international projects. A.M. acknowledges support from the European Research Council under the European Union's Seventh Framework Programme Grant agreement $n^{\circ} 308126$ (LUSI LAB project) and the Research Council of Norway through its Centers of Excellence 
1722 funding scheme, Project Number 223272 (CEED). G.E. acknowledges support from the Deep 1723 Carbon Observatory - Deep Energy programme (Sloan Foundation), NATO C.L.G. (contract 1724 EST.CLG.977422) and MIUR-PRIN 2009 Project (prot. 2009JM4K9M). We are grateful to 1725 the numerous Institutes and people that collaborated with us discussing data and during 1726 fieldwork in Azerbaijan, Indonesia, Iran, Italy, Japan, Romania, Trinidad and in marine 1727 expeditions around Europe. We also thank the editor G. Foulger and two anonymous 1728 reviewers who provided valuable comments. 
Abikh, G. V., 1939, New Islands on the Caspian Sea and the Cognition of Mud Volcanoes of the Caspian Region: Memories Acad. Sc. Peterbourg, 1863, Ser. VIII, vol. 6, no. 5. Translated from the German in Tr. Inst. Geol. Azer., Fil. Akad. Nauk SSSR, v. 12, p. 15-48.

Abrams, M. A., 2005, Significance of hydrocarbon seepage relative to petroleum generation and entrapment: Marine and Petroleum Geology, v. 22, p. 457-477.

Abrams, M. A., and Narimanov, A. A., 1997, Geochemical evaluation of hydrocarbons and their potential sources in the western South Caspian depression, Republic of Azerbaijan: Marine \& Petroleum Geology, v. 14, p. 451-468.

Accaino, F., Bratus, A., Conti, S., Fontana, D., and Tinivella, U., 2007, Fluid seepage in mud volcanoes of the northern Apennines: An integrated geophysical and geological study: Journal of Applied Geophysics, v. 63, p. 90-101.

Akhmetzhanov, A. M., Ivanov, M. K., Kenyon, N., and Mazzini, A., 2007, Deep-water cold seeps, sedimentary environments and echosystems of the Black and Tyrrhenian Seas and the Gulf of Cadiz, IOC Technical Series No. 72, UNESCO, p. 140.

Akhmetzhanov, A. M., Kenyon, N. H., Ivanov, M. K., Westbrook, G., and Mazzini, A., 2008, Deepwater depositional systems and cold seeps of the Western Mediterranean, Gulf of Cadiz and Norwegian continental margins, IOC Technical Series No. 76, UNESCO.

Alain, K., Holler, T., Musat, F., Elvert, M., Treude, T., and Kruger, M., 2006, Microbiological investigation of methane- and hydrocarbon-discharging mud volcanoes in the Carpathian Mountains, Romania: Environmental Microbiology, v. 8, p. 574-590.

Aliyev, A., Guliyev, I. S., and Belov, I. S., 2002, Catalogue of recorded eruptions of mud volcanoes of Azerbaijan, Nafta Press, Baku, 87 p.:

Aliyev, A. A., 2004, Mud volcanism of the South-Caspian oil-gas basin, in South-Caspian Basin: Geology, Geophysics, Oil and Gas Content, Nafta, Baku, Azerbaijan, p. 186-212.

Allen, C. C., Oehler, D. Z., and Baker, D. M., 2009, Mud volcanoes - A new class of sites for geological and astrobiological exploration of Mars.: Lunar Planet. Sci. XXXX. Abstract 1749.

Aloisi, G., Pierre, C., Rouchy, J. M., Foucher, J. P., and Woodside, J., 2000, Methane-related authigenic carbonates of eastern Mediterranean Sea mud volcanoes and their possible relation to gas hydrate destabilisation: Earth and Planetary Science Letters, v. 184, p. 321338.

Aloisi, G., Wallmann, K., and Drews, M., 2004, Evidence for the submarine weathering of silicate minerals in Black Sea sediments: Possible implications for the marine Li and B cycles: Geochemistry Geophysics Geosystems, v. 5.

Ansted, D. T., 1866, On the mud volcanoes of the Crimea, and on the relation of these and similar phenomena to deposits of petroleum: Proc. R. Inst. G.B., v. IV, p. 628-640.

Avouac, J.-P., Ayoub, F., Wei, S., Ampuero, J.-P., Meng, L., Leprince, S., Jolivet, R., Duputel, Z., and Helmberger, D., 2014, The 2013, Mw 7.7 Balochistan earthquake, energetic strike-slip reactivation of a thrust fault: Earth and Planetary Science Letters, v. 391, p. 128-134.

Baciu, C., Caracausi, A., Etiope, G., and Italiano, F., 2007, Mud volcanoes and methane seeps in Romania: main features and gas flux: Annals of Geophysics, v. 50, p. 501-511.

Baciu, C., and Etiope, G., 2005, Mud volcanoes and seismicity in Romania: Mud Volcanoes, Geodynamics and Seismicity, v. 51, p. 77-87

288.

Bagirov, E., Nadirov, R., and Lerche, I., 1996, Flaming Eruptions and Ejections from Mud volcanoes in Azerbaijan: Statistical Risk Assessment from the Historical Record: Energy Exploration and Exploitation, v. 14, p. 535-583. 
Bahr, A., Pape, T., Bohrmann, G., Mazzini, A., Haeckel, M., Reitz, A., and Ivanov, M., 2009, Authigenic carbonate precipitates from the NE Black Sea: a mineralogical, geochemical and lipid biomarker study: International Journal of Earth Sciences, v. 98, p. 677-695.

Bannert, D., Cheema, A., Ahmed, A., and Schluter, U., 1992, The structural development of the Western Fold Belt: Pak. Geol. Jahrb, v. B80, p. 3-60.

Barber, A. J., Tjokosapoetro, S., and Charlton, T. R., 1986, Mud volcanoes, shale diapirs, wrench faults and melanges in accretionary complexes, eastern Indonesia: American Association of Petroleum Geologists Bulletin, v. 70, p. 1729-1741.

Baylis, S. A., Cawley, S. J., Clayton, C. J., and Savell, M. A., 1997, The origin of unusual gas seeps from onshore Papua New Guinea: Marine Geology, v. 137, p. 109-120.

Bellaiche, G., Loncke, L., Gaullier, V., Mascle, J., Courp, T., Moreau, A., Radan, S., and Sardou, O., 2001, Le cône sous-marin du Nil et son réseau de chenaux profonds; nouveaux résultats (campagne Fanil): Comptes Rendus de l'Academie des Sciences, Serie II. Sciences de la Terre et des Planètes, (2001), pp. , v. 333, p. 399-404.

Berndt, C., et al., 2007, Geological controls on fluid flow from the Mercator Mud Volcano, Gulf of Cadiz: EGU General Assembly, Vienna, April 15-20, 2007. .

Bessonova, E. P., Bortnikova, S. B., Gora, M. P., Manstein, Y. A., Shevko, A. Y., Panin, G. L., and Manstein, A. K., 2012, Geochemical and geo-electrical study of mud pools at the Mutnovsky volcano (South Kamchatka, Russia): Behavior of elements, structures of feeding channels and a model of origin: Applied Geochemistry, v. 27, p. 1829-1843.

Boetius, A., and Suess, E., 2004, Hydrate Ridge: a natural laboratory for the study of microbial life fueled by methane from near-surface gas hydrates: Chemical Geology, v. 205, p. 291-310.

Boetius, A., and Wenzhöfer, F., 2013, Seafloor oxygen consumption fuelled by methane from cold seeps: Nature Geoscience, v. 6, p. 725-734.

Bonini, M., and Mazzarini, F., 2010, Mud volcanoes as potential indicators of regional stress and pressurized layer depth: Tectonophysics, v. 494, p. 32-47.

Bonini, M., Rudolph, M. L., and Manga, M., 2016, Long- and short-term triggering and modulation of mud volcano eruptions by earthquakes: Tectonophysics, v. 672-673, p. 190-211.

Bradak, B., and Kereszturi, A., 2003, Mud volcanism as a model for various planetary surface processes: Lunar Planet. Sci., v. 34, p. Abstract 1304.

Brodsky, E. E., Roeloffs, E., Woodcock, D., Gall, I., and M., M., 2003, A mechanism for sustained groundwater pressure changes induced by distant earthquakes: Journal of Geophysical Research, v. 108, p. 7.1-7.10.

Brown, K., and Westbrook, G. K., 1988, Mud Diapirism and Subcretion in the Barbados Ridge Accretionary Complex - the Role of Fluids in Accretionary Processes: Tectonics, v. 7, p. 613640.

Bruning, M., Sahling, H., MacDonald, I. R., Ding, F., and Bohrmann, G., 2010, Origin, distribution, and alteration of asphalts at Chapopote Knoll, Southern Gulf of Mexico: Marine and Petroleum Geology, v. 27, p. 1093-1106.

Capozzi, R., and Picotti, V., 2002, Fluid migration and origin of a mud volcano in the Northern Apennines (Italy): the role of deeply rooted normal faults: Terra Nova, v. 14, p. 363-370.

Carpenter, A. B., and Miller, J. C., 1969, Geochemistry of saline subsurface water, Saline County (Missouri). Chemical Geology, v. 4, p. 135-167.

CGG, 2015, Organic Geochemistry Data from FRogi and the Fluid Features Database. http://robertson.cgg.com/products/frogi.

Chen, S.-C., Hsu, S.-K., Wang, Y., Chung, S.-H., Chen, P.-C., Tsai, C.-H., Liu, C.-S., Lin, H.-S., and Lee, Y.W., 2014, Distribution and characters of the mud diapirs and mud volcanoes off southwest Taiwan: Journal of Asian Earth Sciences, v. 92, p. 201-214.

Cheng, T. W., et al., 2012, Metabolic stratification driven by surface and subsurface interactions in a terrestrial mud volcano: Isme Journal, v. 6, p. 2280-2290. 
Chigira, M., and Tanaka, K., 1997, Structural features and history of mud volcanoes in southern Kokkaido, northern Japan: Journal - Geological Society of Japan, v. 103, p. 781-793.

Ciais, P., et al., 2013, Carbon and other biogeochemical cycles., in Stocker, T. F., ed., Climate change 2013: the physical science basis. Contribution of working group I to the fifth assessment report of IPCC, Cambridge University Press, Cambridge.

Ciocardel, R., 1949, Regiunea petrolifera Berca - Beciu- Arbanasi: Inst. Geol., St. Tehn. Ec., v. A4, p. 132.

Ciotoli, G., Etiope, G., Marra, F., Florindo, F., Giraudi, C., and Ruggiero, L., 2016, Tiber delta CO2-CH4 degassing: a possible hybrid, tectonically active Sediment-Hosted Geothermal System near Rome: J. Geophys. Res. Solid Earth, v. 121, doi: 10.1002/2015JB012557.

Cita, M. B., et al., 1982, Stratigraphy and neotectonics in the Eastern Mediterranean Ridge, Cobblestone area 3 revisited: Mem. Soc. Geol. Ital., v. 24, p. 443-458.

Cita, M. B., and Camerlenghi, A., 1990, The Mediterranean Ridge as an accretionary prism in collisional context. Atti del 75 congresso nazionale della Societa Geologica Italiana "La geologia italiana degli anni' 90": Mem Soc Geol Ital, v. 45, p. 463-480.

Cita, M. B., et al., 1989, Discovery of mud diapirism on the Mediterranean ridge; a preliminary report: Bollettino della Societa Geologica Italiana, v. 108, p. 537-543.

Cita, M. B., Ivanov, M. K., and Woodside, J. M., 1996, The Mediterranean Ridge Diapiric Belt: Special Issue, Marine Geology, v. 132, p. 273. pp.

Cita, M. B., Ryan, W. B. F., and Paggi, L., 1981, Prometheus mudbreccia: An example of shale diapirism in the Western Mediterranean Ridge: Ann. Geol. Pays Hellen., v. 30, p. 543-570.

Clari, P., Cavagna, S., Martire, L., and Hunziker, J., 2004, A miocene mud volcano and its plumbing system: A chaotic complex revisited (Monferrato, NW Italy): Journal of Sedimentary Research, v. 74, p. 662-676.

Class@Baikal, http://www.baikal.festivalnauki.ru/en.

Coelho, F. J. R. C., Louvado, A., Domingues, P. M., Cleary, D. F. R., Ferreira, M., Almeida, A., Cunha, M. R., Cunha, Â., and Gomes, N. C. M., 2016, Integrated analysis of bacterial and microeukaryotic communities from differentially active mud volcanoes in the Gulf of Cadiz: Scientific Reports, v. 6, p. 35272.

Collignon, M., Schmid, D. W., and Mazzini, A., 2016, Fluid flow modeling at the Lusi mud eruption, East java, Indonesia: EGU General Assembly, Vienna, April 17-22, 216. X1.285 EGU20167149.

Collins, A. G., 1975, Geochemistry of oilfield waters.: Elsevier , New York.

Connolly, J. A. D., and Podladchikov, Y. Y., 2015, An analytical solution for solitary porosity waves: dynamic permeability and fluidization of nonlinear viscous and viscoplastic rock: Geofluids, v. 15, p. 269-292.

Cooper, C., 2001, Mud volcanoes of Azerbaijan visualized using 3D seismic depth cubes: the importance of overpressured fluid and gas instead of non extant diapirs: Abstract Vol. Subsurface Sediment Mobilization Conf, 10-13 September, Ghent, Belgium, p. 71.

Corthay, J. E., and Aliev, A. I., 2000, Delineation of a Mud Volcano Complex, Surficial Mudflows, Slump Blocks, and Shallow Gas Reservoirs, Offshore Azerbaijan: Offshore Technology Conference, v. 12066-MS.

Craig, H., 1961, Isotopic variations in meteoric waters: Science v. 133, p. 1702-1703.

Dadashev, F. G., Guseynov, R. A., and Aliev, A. I., 1995, Map of Mud Volcanoes of the Caspian Sea,, in Yusifzade, H. B., and Guliev, I. S., eds., Academy of Sciences of Azerbaijan Republic, Geology Institute, p. 15p.

Dang_news, 2016, Tang mud volcano, Kenarak county, started its strange activity after years of silence.: http://dana.ir/670386.

Davies, R. J., Mathias, S. A., Swarbrick, R. E., and Tingay, M. J., 2011, Probabilistic longevity estimate for the LUSI mud volcano, East Java: Journal of the Geological Society, v. 168, p. 517-523. 
Davis, P. A., and Tanaka, K. L., 1995, Curvilinear ridges in Isidis Planitia, Mars - The result of mud volcanism? : Lunar Planet. Sci. XXIV, 321-322.

Delisle, G., Teschner, M., Panahi, B., Guliev, I. S., Aliyev, A., and Faber, E., 2005, Preliminary results of methane seepage monitoring at Dashgil Mud Volcano (Azerbaijan): Proceedings, The sciences of Earth, v. 4, p. 11-23.

Delisle, G., von Rad, U., Andruleit, H., van Daniels, C., Tabreez, A., and A., I., 2002a, Active mud volcanoes on- and offshore eastern Makran, Pakistan: International Journal of Earth Sciences, v. 91, p. 93-110.

Delisle, G., von Rad, U., Andruleit, H., von Daniels, C. H., Tabrez, A. R., and Inam, A., 2002b, Active mud volcanoes on- and offshore eastern Makran, Pakistan: International Journal of Earth Sciences, v. 91, p. 93-110.

Delle Donne, D., Harris, A. J. L., Ripepe, M., and Wright, R., 2010, Earthquake-induced thermal anomalies at active volcanoes: Geology, v. 38, p. 771-774.

Deville, E., Battani, A., Griboulard, R., Guerlais, S. H., Herbin, J. P., Houzay, J. P., Muller, C., and Prinzhofer, A., 2003, Mud volcanism origin and processes. New insights from Trinidad and the Barbados Prism, in Van Rensbergen, P., Hillis, R. R., Maltman, A. J., and Morley, C., eds., Surface Sediment Mobilization, Volume 216, Special publication of the Geological Society (London) p. 475-490.

Deville, E., and Guerlais, S. H., 2009, Cyclic activity of mud volcanoes: Evidences from Trinidad (SE Caribbean): Marine and Petroleum Geology, v. 26, p. 1681-1691.

Dia, A. N., Castrec-Rouelle, M., Boulegue, J., and Comeau, P., 1999, Trinidad mud volcanoes: where do the expelled fluids come from?: Geochimica et Cosmochimica Acta, v. 63, p. 1023-1038.

Dia, A. N., Castrec, M., Boulègue, J., and Boudou, J. P., 1995, Major and trace element and Sr isotope constraints on fluid circulations in the Barbados accretionary complex. Part 1: Fluid origin: Earth and Planetary Science Letters, v. 134, p. 69-85.

Dimitrov, L. I., 2002, Mud volcanoes--the most important pathway for degassing deeply buried sediments: Earth-Science Reviews, v. 59, p. 49-76.

Dupré, S., Buffet, G., Mascle, J., Foucher, J. P., Gauger, S., Boetius, A., and Marfia, C., 2008, Highresolution mapping of large gas emitting mud volcanoes on the Egyptian continental margin (Nile Deep Sea Fan) by AUV surveys: Marine Geophysical Researches, v. 29, p. 275-290.

Dupré, S., et al., 2007, Seafloor geological studies above active gas chimneys off Egypt (Central Nile Deep Sea Fan): Deep Sea Research Part I: Oceanographic Research Papers, v. 54, p. 11461172.

Dählmann, A., and de Lange, G. J., 2003, Fluid-sediment interactions at Eastern Mediterranean mud volcanoes: a stable isotope study from ODP Leg 160: Earth and Planetary Science Letters, v. 212, p. 377-391.

Eggert, S., and Walter, T. R., 2008, Volcanic activity before and after large tectonic earthquakes: Observations and statistical significance: Tectonophysics, v. In Press, Accepted Manuscript doi: 10.1016/j.tecto.2008.10.003.

Ellouz-Zimmermann, N., et al., 2007, Offshore frontal part of the Makran accretionary prism (Pakistan): The CHAMAK survey, in Lacombe, O., and Roure, F., eds., Thrust belts and Foreland Basins, Special Volume: Springer-Verlag, Chapter 18, p. 349-364.

Etiope, G., 2015, Natural Gas Seepage. The Earth's hydrocarbon degassing: Springer International Publishing Switzerland, ISBN 978-3-319-14601-0 (eBook), DOI 10.1007/978-3-319-14601-0., p. 199.

Etiope, G., Baciu, C. L., and Schoell, M., 2011a, Extreme methane deuterium, nitrogen and helium enrichment in natural gas from the Homorod seep (Romania): Chemical Geology, v. 280, p. 89-96.

Etiope, G., Feizullayev, A. A., Baciu, C. L., and Milkov, A., 2004, Methane emission from mud volcanoes in eastern Azerbaijan: Geology, v. 32, p. 465-468. 
Etiope, G., Feyzullayev, A., and Baciu, C. L., 2009a, Terrestrial methane seeps and mud volcanoes: A global perspective of gas origin: Marine and Petroleum Geology, v. 26, p. 333-344.

Etiope, G., Feyzullayev, A., Milkov, A. V., Waseda, A., Mizobe, K., and Sun, C. H., 2009b, Evidence of subsurface anaerobic biodegradation of hydrocarbons and potential secondary methanogenesis in terrestrial mud volcanoes: Marine and Petroleum Geology, v. 26, p. 1692-1703.

Etiope, G., and Klusman, R. W., 2002, Geologic emissions of methane to the atmosphere: Chemosphere, v. 49, p. 777-789.

Etiope, G., and Martinelli, G., 2009, "Pieve Santo Stefano" is not a mud volcano: Comment on "Structural controls on a carbon dioxide-driven mud volcano field in the Northern Apennines" (by Bonini, 2009): Journal of Structural Geology, v. 31, p. 1270-1271.

Etiope, G., Martinelli, G., Caracausi, A., and Italiano, F., 2007, Methane seeps and mud volcanoes in Italy: gas origin, fractionation and emission to the atmosphere: Geophysical Research Letters, v. 34, L14303, doi: 10.1029/2007GL030341.

Etiope, G., and Milkov, A., 2004, A new estimate of global methane flux from onshore and shallow submarine mud volcanoes to the atmosphere: Environmental Geology, v. 46, p. 997-1002.

Etiope, G., Nakada, R., Tanaka, K., and Yoshida, N., 2011b, Gas seepage from Tokamachi mud volcanoes, onshore Niigata Basin (Japan): origin, post-genetic alterations and $\mathrm{CH}_{4}-\mathrm{CO}_{2}$ fluxes.: Applied Geochemistry, v. 26, p. 348-359.

Etiope, G., Oehler, D. Z., and Allen, C. C., 2011c, Methane emissions from Earth's degassing: Implications for Mars: Planetary and Space Science, v. 59, p. 182-195.

Etiope, G., and Sherwood Lollar, B., 2013, Abiotic Methane on Earth: Reviews of Geophysics, v. 51, p. 276-299.

Farías, C., Lupi, M., Fuchs, F., and Miller, S. A., 2014, Seismic activity of the Nevados de Chillán volcanic complex after the 2010 Mw8.8 Maule, Chile, earthquake: Journal of Volcanology and Geothermal Research, v. 283, p. 116-126.

Farrand, W. H., Gaddis, L. R., and Keszthelyi, L., 2005, Pitted cones and domes on Mars: Observations in Acidalia Planitia and Cydonia Mensae using MOC, THEMIS, and TES data: Journal of Geophysical Research-Planets, v. 110.

Feseker, T., Boetius, A., Wenzhöfer, F., Blandin, J., Olu, K., Yoerger, D. R., Camilli, R., German, C. R., and de Beer, D., 2014, Eruption of a deep-sea mud volcano triggers rapid sediment movement: Nat Commun, v. 5.

Feseker, T., Dahlmann, A., Foucher, J. P., and Harmegnies, F., 2009, In-situ sediment temperature measurements and geochemical porewater data suggest highly dynamic fluid flow at Isis mud volcano, eastern Mediterranean Sea: Marine Geology, v. 261, p. 128-137.

Feseker, T., Foucher, J. P., and Harmegnies, F., 2008, Fluid flow or mud eruptions? Sediment temperature distributions on Hakon Mosby mud volcano, SW Barents Sea slope: Marine Geology, v. 247, p. 194-207.

Feyzullayev, A., and Movsumova, U., 2001, About the origin of isotopically heavy CO2 in gases of Azerbaijan mud volcanoes. : Azerb. Geol., v. 6.

Fortes, A. D., and Grindrod, P. M., 2006, Modelling of possible mud volcanism on Titan: Icarus, v. 182, p. 550-558.

Foucher, J. P., Dupre, S., Scalabrin, C., Feseker, T., Harmegnies, F., and Nouze, H., 2010, Changes in seabed morphology, mud temperature and free gas venting at the Håkon Mosby mud volcano, offshore northern Norway, over the time period 2003-2006: Geo-Marine Letters, v. 30, p. 157-167.

Fournier, R. O., and Truesdell, A. H., 1973, An empirical Na-K-Ca chemical thermometer for natural waters: Geochim Cosmochim Acta, v. 37, p. 1255-1275.

Fowler, S. R., Mildenhall, J., Zalova, S., Riley, G., Elsley, G., Desplanques, A., and Guliyev, I., 2000, Mud volcanoes and structural development on Shah Deniz: Journal of Petroleum Science Engineering, v. 28, p. 189-206. 
Gieskes, J. M., and Mahn, C., 2007, Halide systematics in interstitial waters of ocean drilling sediment cores: Applied Geochemistry, v. 22, p. 515-533.

Ginsburg, G. D., and Soloviev, V. A., 1994, Mud volcano gas hydrates in the Caspian Sea: Bulletin of the Geological Society of Denmark, v. 41, p. 95-100.

Gisler, G., 2009, Simulations of the explosive eruption of superheated fluids through deformable media: Marine and Petroleum Geology, v. 26, p. 1888-1895.

Gontharet, S., Pierre, C., Blanc-Valleron, M. M., Rouchy, J. M., Fouquet, Y., Bayon, G., Foucher, J. P., Woodside, J., and Mascle, J., 2007, Nature and origin of diagenetic carbonate crusts and concretions from mud volcanoes and pockmarks of the Nile deep-sea fan (eastern Mediterranean Sea): Deep Sea Research Part II: Topical Studies in Oceanography, v. 54, p. 1292-1311.

Goubkin, I. M., and Fedorov, S. F., 1938, Mud volcanoes of the Soviet Union and their connection with the genesis of petroleum fields in Crimean-Caucasus geologic province. : USSR Academy of Science, Moscow (in Russian).

Green-Saxena, A., Feyzullayev, A., Hubert, R. J., Kallmeyer, J., Krueger, M., Sauer, P., Schulz, H.-M., and Orphan, V. J., 2012, Active sulfur cycling by diverse mesophilic and thermophilic microorganisms in terrestrial mud volcanoes of Azerbaijan: Environmental Microbiology, v. 14, p. 3271-3286.

Greinert, J., Bohrmann, G., and Suess, E., 2001, Gas hydrate-associated carbonates and methaneventing at Hydrate Ridge classification, distribution, and origin of authigenic lithologies., in Paull, C. K., and Dillon, W. K., eds., Natural Gas Hydrates: Occurrence, Distribution and Detection, Geophysical Monograph 124, American Geophysical Union, p. 99-113.

Greinert, J., Lewis, K. B., Bialas, J., Pecher, I. A., Rowden, A., Bowden, D. A., De Batist, M., and Linke, P., 2010, Methane seepage along the Hikurangi Margin, New Zealand: Overview of studies in 2006 and 2007 and new evidence from visual, bathymetric and hydroacoustic investigations: Marine Geology, v. 272, p. 6-25.

Guliev, I. S., and Feizullayev, A. A., 1997, All about Mud volcanoes, Nafta Press, Baku, 52 p.:

Guliyev, I. S., and Feizullayev, A. A., 1997, All about Mud volcanoes, Nafta Press, Baku, 52 p.:

Guliyev, I. S., Huseynov, D. A., and Feizullayev, A. A., 2004, Fluids of Mud Volcanoes in the Southern Caspian Sedimentary Basin: Geochemistry and Sources in Light of New Data on the Carbon, Hydrogen, and Oxygen Isotopic Compositions: Geochemistry International, v. 42, p. 688-695.

Haas, A., Peckmann, J., Elvert, M., Sahling, H., and Bohrmann, G., 2010, Patterns of carbonate authigenesis at the Kouilou pockmarks on the Congo deep-sea fan: Marine Geology, v. 268, p. 129-136.

Haffert, L., et al., 2013, Fluid evolution and authigenic mineral paragenesis related to salt diapirism The Mercator mud volcano in the Gulf of Cadiz: Geochimica et Cosmochimica Acta, v. 106, p. 261-286.

Hanor, J. S., 1994, Origin of saline fluids in sedimentary basins, in Parnell, J., ed., Geofluids: origin, migration and evolution of fluids in sedimentary basins, Volume 78, Geol Soc Spec Publ p. 151-174.

Helgeson, H. C., 1968, Geologic and Thermodynamic Characteristics of Salton Sea Geothermal System: American Journal of Science, v. 266, p. 129-166.

Heller, C., Blumenberg, M., Hoppert, M., Taviani, M., and Reitner, J., 2012, Terrestrial mud volcanoes of the Salse di Nirano (Italy) as a window into deeply buried organic-rich shales of PlioPleistocene age: Sedimentary Geology, v. 263, p. 202-209.

Heller, C., Blumenberg, M., Kokoschka, S., Wrede, C., Hoppert, M., Taviani, M., and Reitner, J., 2011, Geomicrobiology of Fluid Venting Structures at the Salse di Nirano Mud Volcano Area in the Northern Apennines (Italy), in Reitner, J., Queric, N. V., and Arp, G., eds., Advances in Stromatolite Geobiology, Volume XII, Springer, p. 560. 
Henry, P., et al., 1996, Fluid flow in and around a mud volcano field seaward of the Barbados accretionary wedge: Results from Manon cruise: Journal of Geophysical Research, v. 101, B9, p. 20297-20323.

Hensen, C., Nuzzo, M., Hornibrook, E., Pinheiro, L. M., Bock, B., Magalhaes, V. H., and Bruckmann, W., 2007, Sources of mud volcano fluids in the Gulf of Cadiz - indications for hydrothermal imprint: Geochimica et Cosmochimica Acta, v. 71, p. 1232-1248.

Hensen, C., et al., 2015, Strike-slip faults mediate the rise of crustal-derived fluids and mud volcanism in the deep sea: Geology, v. 43, p. 339-342.

Hensen, C., Wallmann, K., Schmidt, M., Ranero, C. R., and Suess, E., 2004, Fluid expulsion related to mud extrusion off Costa Rica - A window to the subducting slab: Geology, v. 32, p. 201-204.

Hieke, W., 2004, The August 27, 1886 earthquake in Messenia (Peloponnesus) and reported flames over the Ionian Sea--a Mediterranean Ridge gas escape event?: Marine Geology, v. 207, p. 259-265.

Holford, S. P., Schofield, N., Jackson, C. A.-L., Magee, C., Green, P. F., and Duddy, I. R., 2013, Impacts of igneous intrusions on source and reservoir potential in prospective sedimentary basins along the Western Australian Continental Margin., in Keep, M., and Moss, S. J., eds.: The Sedimentary Basins of Western Australia IV. Proceedings of the Petroleum Exploration Society of Australia Symposium, Perth, WA, 2013.

Hong, W. L., Etiope, G., Yang, T. F., and Chang, P. Y., 2013, Methane flux from miniseepage in mud volcanoes of SW Taiwan: Comparison with the data from Italy, Romania, and Azerbaijan: Journal of Asian Earth Sciences, v. 65, p. 3-12.

Hovland, M., Talbot, M. R., Qvale, H., Olaussen, S., and Aasberg, L., 1987, Methane-related carbonate cements in pockmarks of the North Sea.: Journal of Sedimentary Petrology, v. 57, p. 881-892.

Hunt, J. M., 1996, Petroleum Geochemistry and Geology Freeman (2nd ed.), 743 p.:

Husen, S., Taylor, R., Smith, R. B., and Heasler, H., 2004, Changes in geyser eruption behavior and remotely triggered seismicity in Yellowstone National Park produced by the 2002 M 7.9 Denali fault earthquake, Alaska: Geology, v. 32, p. 537-540.

Huseynov, D. A., and Guliyev, I. S., 2004, Mud volcanic natural phenomena in the South Caspian Basin: geology, fluid dynamics and environmental impact: Environmental Geology, v. 46, p. 1012-1023.

Inan, S., Namik Yalcin, M., Guliyev, I. S., Kuliev, K., and Feizullayev, A. A., 1997, Deep petroleum occurrences in the Lower Kura Depression, South Caspian Basin, Azerbaijan: an organic geochemical and basin modelling study: Marine \& Petroleum Geology, v. 14, p. 731-762.

Isaksen, G. H., Aliyev, A., Barboza, S. A., Plus, D., and Guliev, I. S., 2007, Regional evaluation of source rock in Azerbaijan from the geochemistry of organic-rich rocks in mud-volcano ejecta, in Yilmaz, P. O., and Isaksen, G. H., eds., Oil and gas of the Greater Caspian area, AAPG Studies in Geology, 55, p. 51-64.

Istadi, B. P., Pramono, G. H., Sumintadireja, P., and Alam, S., 2009, Modeling study of growth and potential geohazard for LUSI mud volcano: East Java, Indonesia: Marine and Petroleum Geology, v. 26, p. 1724-1739.

Ivanov, M., Kenyon, N., Laberg, J. S., and Blinova, V., 2010, Cold seeps, coral mounds and deep-water depositional systems of the Alboran Sea, Gulf of Cadiz and Norwegian continental margin.: IOC Technical Series 94, UNESCO, p. 144.

Ivanov, M., Limonov, A. F., and Woodside, J., 1992, Geological and Geophysical Investigations in the Mediterranean and Black Seas: Initial Results of the "Training Through Research" Cruise of RV Gelendzhik in the Eastern Mediterranean and the Black Sea (June - July 1991). UNESCO Reports in Marine Science, v. 56, p. 208.

Ivanov, M. A., Hiesinger, H., Erkeling, G., and Reiss, D., 2014, Mud volcanism and morphology of impact craters in Utopia Planitia on Mars: Evidence for the ancient ocean: Icarus, v. 228, p. 121-140. 
Ivanov, M. K., Konyukhov, A. U., Kulnitskii, L. M., and Musatov, A. A., 1989, Mud volcanoes in deep part of the Black Sea: Vestnik MGU, v. Ser. Geol. 3, p. 21-31 (in Russian).

Ivanov, M. K., Limonov, A. F., and Cronin, B., 1996a, Mud volcanism and fluid venting in the eastern part of the Mediterranean Ridge, UNESCO Reports in Marine Science, Volume 68, p. 126.

Ivanov, M. K., Limonov, A. F., and van Weering, T. C. E., 1996b, Comparative characteristics of the Black Sea and Mediterranean Ridge mud volcanoes: Marine Geology, v. 132, p. 253-271.

Iyer, K., Rupke, L., and Galerne, C. Y., 2013, Modeling fluid flow in sedimentary basins with sill intrusions: Implications for hydrothermal venting and climate change.: Geochem. Geophys. Geosyst., v. 14, p. 5244-5262.

Jackson, J. A., 1997, Glossary of Geology, American Geological Institute, fourth edition, p. 769.

Jakubov, A. A., AliZade, A. A., and Zeinalov, M. M., 1971, Mud volcanoes of the Azerbaijan SSR: Atlas (in Russian), Azerbaijan Academy of Sciences, Baku.

Jamtveit, B., Svensen, H., Podladchikov, Y., and Planke, S., 2004, Hydrothermal vent complexes associated with sill intrusions in sedimentary basins: Geological Society, London, Special Publications, v. 234, p. 233-241.

Jeffrey, A. W. A., Alimi, H.M., Jenden, P.D., ., 1991, Geochemistry of the Los Angelesc Basin oil and gas systems. In: Biddle, K.T. (Ed.), Active Margin Basins: American Association of Petroleum Geologists Memoir, v. 52, p. 197-219.

Jenden, P. D., Hilton, D. R., Kaplan, I. R., and Craig, H., 1993, Abiogenic hydrocarbons and mantle helium in oil and gas fields, in Howell, D. G., ed., The Future of Energy Gases, (US Geological Survey Professional Paper 1570), United States Government Printing Office, Washington, p. 31-56.

Jerosch, K., Schlüter, M., and Pesch, R., 2006, Spatial analysis of marine categorical information using indicator kriging applied to georeferenced video mosaics of the deep-sea Håkon Mosby Mud Volcano: Ecological Informatics, v. 1, p. 391-406.

Judd, A., and Hovland, M., 2007 Seabed Fluid Flow, Cambridge University Press, Cambridge, 475 p.:

Kalitskii, K. P., 1914, Boya-Dag: Izv. SPb. Geolkoma, v. 238.

Kaul, N., Foucher, J. P., and Heesemann, M., 2006, Estimating mud expulsion rates from temperature measurements on Håkon Mosby Mud Volcano, SW Barents Sea: Marine Geology, v. 229, p. 1-14.

Kenyon, N., Ivanov, M., and Akhmetjanov, A. M., 1998, Cold water carbonate mounds and sediment transport on the Northeast Atlantic margin: IOC Technical Series No. 52, UNESCO, p. 178.

Kenyon, N., Ivanov, M., Akhmetjanov, A. M., and Kozlova, E., 2006, Interdisciplinary geoscience studies of the Gulf of Cadiz and Western Mediterranean basins.: IOC Technical Series No. 70, UNESCO, p. 115.

Kenyon, N. H., Ivanov, M. K., and Akhmetzhanov, A. M., 1999, Geological Processes on the Northeast Atlantic Margin., Technical Series- Intergovernmental Oceanographic Commission, Volume 54, p. 141.

Kenyon, N. H., Ivanov, M. K., Akhmetzhanov, A. M., and Akhmanov, G. G., 2000, Multidisciplinary Study of Geological Processes on the North East Atlantic and Western Mediterranean Margins, Technical Series- Intergovernmental Oceanographic Commission, Volume 56, p. 102.

Kenyon, N. H., Ivanov, M. K., Akhmetzhanov, A. M., and Akhmanov, G. G., 2001, Multidiplinary Study of Geological Processes on the North East Atlantic Margin and Mid-Atlantic ridge., Technical Series- Intergovernmental Oceanographic Commission, Volume 60, p. 142.

Kenyon, N. H., Ivanov, M. K., Akhmetzhanov, A. M., and Akhmanov, G. G., 2002, Geological Processes in the Mediterranean and Black Seas and North East Atlantic, Technical SeriesIntergovernmental Oceanographic Commission, Volume 62, p. 123.

Kenyon, N. H., Ivanov, M. K., Akhmetzhanov, A. M., and Akhmanov, G. G., 2003, Interdisciplinary Geoscience Research on the North East Atlantic Margin, Mediterranean Sea and Mid- 
Atlantic Ridge, Technical Series- Intergovernmental Oceanographic Commission. , UNESCO, (English), Volume 67, p. 112.

Kenyon, N. H., Ivanov, M. K., Akhmetzhanov, A. M., Kozlova, E., and Mazzini, A., 2004, Interdisciplinary studies of North Atlantic and Labrador Sea Margin Architecture and Sedimentary Processes, Technical Series- Intergovernmental Oceanographic Commission, UNESCO, (English), Volume 68, p. 92.

Kholodov, V. N., 2002, Mud Volcanoes, Their Distribution Regularities and Genesis: Communication 1. Mud Volcanic Provinces and Morphology of Mud Volcanoes: Lithology and Mineral Resources, v. 37, p. 197-209.

Kirkham, C., Cartwright, J., Hermanrud, C., and Jebsen, C., 2017, The spatial, temporal and volumetric analysis of a large mud volcano province within the Eastern Mediterranean: Marine and Petroleum Geology, v. 81, p. 1-16.

Kite, E. S., Hovius, N., Hillier, J. K., and Besserer, J., 2007, Candidate mud volcanoes in the Northern Plains of Mars: American Geophysical Union, Fall Meeting 2007 (abstract \#V13B-1346).

Kocherla, M., Teichert, B. M. A., Pillai, S., Satyanarayanan, M., Ramamurthy, P. B., Patil, D. J., and Rao, A. N., Formation of methane-related authigenic carbonates in a highly dynamic biogeochemical system in the Krishna-Godavari Basin, Bay of Bengal: Marine and Petroleum Geology.

Kokoschka, S., Dreier, A., Romoth, K., Taviani, M., Schafer, N., Reitner, J., and Hoppert, M., 2015, Isolation of Anaerobic Bacteria from Terrestrial Mud Volcanoes (Salse di Nirano, Northern Apennines, Italy): Geomicrobiology Journal, v. 32, p. 355-364.

Komatsu, G., et al., 2016, Small edifice features in Chryse Planitia, Mars: Assessment of a mud volcano hypothesis: Icarus, v. 268, p. 56-75.

Kopf, A., Delisle, G., Faber, E., Panahi, B., Aliyev, C., and Guliyev, I., 2010a, Erratum to: Long-term in situ monitoring at Dashgil mud volcano, Azerbaijan: a link between seismicity, pore-pressure transients and methane emission: International Journal of Earth Sciences, v. 99, p. 241.

Kopf, A., Delisle, G., Faber, E., Panahi, B., Aliyev, C., and Guliyev, I., 2010b, Long-term in situ monitoring at Dashgil mud volcano, Azerbaijan: a link between seismicity, pore-pressure transients and methane emission: International Journal of Earth Sciences.

Kopf, A., and Deyhle, A., 2002, Back to the roots: boron geochemistry of mud volcanoes and its implications for mobilization depth and global B cycling: Chemical Geology, v. 192, p. 195210.

Kopf, A. J., 2002, Significance of mud volcanism: Review of Geophysics, v. 40, p. 1-52.

Kvenvolden, K. A., and Rogers, B. W., 2005, Gaia's breath-global methane exhalations: Marine and Petroleum Geology, v. 22, p. 579-590.

Lagunova, I. A., 1974, On the origin of carbon dioxide in the gases of mud volcanoes of the KerchTaman region. : Geochem Int, v. 11, p. 1209-1214.

Lance, S., Henry, P., Le Pichon, X., Lallemant, S., Chamley, H., Rostek, F., Faugères, J.-C., Gonthier, E., and Olu, K., 1998, Submersible study of mud volcanoes seaward of the Barbados accretionary wedge: sedimentology, structure and rheology: Marine Geology, v. 145, p. 255292.

Lavrushin, V., Dubinina, E., and Avdeenko, A., 2005, Isotopic composition of oxygen and hydrogen in mud-volcanic waters from Taman (Russia) and Kakhetia (Eastern Georgia): Lithology and Mineral Resources, v. 40, p. 123-137.

Le Pichon, X., Foucher, J. P., Boulegue, J., Henry, P., Lallemant, S., Benedetti, E. L., Avedik, F., and Mariotti, A., 1990, Mud volcano field seaward of the Barbados accretionary complex: a submersible survey: Journal of Geophysical Research, v. 95, p. 8931-8943.

Lemarchand, N., and Grasso, J.-R., 2007, Interactions between earthquakes and volcano activity: Geophysical Research Letters, v. 34 (24), p. p. L24303. 
Limonov, A. F., Kenyon, M., Ivanov, A., and Woodside, J., 1995, Deep sea depositional systems of the Western Mediterranean amd mud volcanism on the Mediterranean Ridge: UNESCO Reports in Marine Science, v. 67, p. 168.

Limonov, A. F., Woodside, J., and Ivanov, M. K., 1994, Mud volcanism in the Mediterranean and Black Sea and shallow structure of the Eratostene seamount., UNESCO Reports in Marine Science, Volume 64, p. 173.

Limonov, A. F., Woodside, J. M., Cita, M. B., and Ivanov, M. K., 1996, The Mediterranean Ridge and related mud diapirism: a background: Marine Geology, v. 132, p. 7-19.

Limonov, A. F., Woodside, J. M., and Ivanov, M. K., 1993, Geological and geophysical investigations of Western Mediterranean deep sea fans: initial results of the UNESCO-ESF "training through-research" cruise of RV Gelendzhik in the Western Mediterranean (June-July 1992): UNESCO Reports in Marine Science, v. 62, p. 154.

Linde, A., and Sacks, I. S., 1998, Triggering of volcanic eruptions: Nature, v. 857 p. 888-890.

Link, W. K., 1952, Significance of oil and gas seeps in world oil exploration: Am. Assoc. Pet. Geol. Bull., v. 36, p. 1505-1540.

Lu, Z., Hensen, C., Fehn, U., and Wallmann, K., 2007, Old iodine in fluids venting along the Central American convergent margin: Geophysical Research Letters, v. 34, p. L22604.

Lupi, M., Ricci, B. S., Kenkel, J., Ricci, T., Fuchs, F., Miller, S. A., and Kemna, A., 2016, Subsurface fluid distribution and possible seismic precursory signal at the Salse di Nirano mud volcanic field, Italy: Geophysical Journal International, v. 204, p. 907-917.

Lupi, M., Saenger, E. H., Fuchs, F., and Miller, S. A., 2013, Lusi mud eruption triggered by geometric focusing of seismic waves: Nature Geoscience, v. 6, p. 642-646.

-, 2014, Lusi mud eruption triggered by geometric focusing of seismic waves (vol 6, pg 642, 2013): Nature Geoscience, v. 7, p. 687-688.

Lykousis, V., et al., 2009, Mud volcanoes and gas hydrates in the Anaximander mountains (Eastern Mediterranean Sea): Marine and Petroleum Geology, v. 26, p. 854-872.

MacDonald, I. R., et al., 2004, Asphalt volcanism and chemosynthetic life in the Campeche Knolls, Gulf of Mexico: Science, v. 304, p. 999-1002.

Madonia, P., Grassa, F., Cangemi, M., and Musumeci, C., 2011, Geomorphological and geochemical characterization of the 11 August 2008 mud volcano eruption at S. Barbara village (Sicily, Italy) and its possible relationship with seismic activity: Natural Hazards and Earth System Sciences, v. 11, p. 1545-1557.

Magalhães, V. H., et al., 2012, Formation processes of methane-derived authigenic carbonates from the Gulf of Cadiz: Sedimentary Geology, v. 243-244, p. 155-168.

Magalhães, V. H., et al., Formation processes of methane-derived authigenic carbonates from the Gulf of Cadiz: Sedimentary Geology.

Magoon, L. B., and Schmoker, J. W., 2000, The Total Petroleum System - the natural fluid network that constraints the assessment units, World Energy Assessment Team, U.S. Geological Survey World Petroleum Assessment 2000- Description and results, 31 p.:

Manga, M., and Brodsky, E., 2006, Seismic Triggering of Eruptions in the Far Field: Volcanoes and Geysers: Annual Review of Earth and Planetary Sciences, v. 34, p. 263-291.

Manga, M., Brumm, M., and Rudolph, M. L., 2009, Earthquake triggering of mud volcanoes: Marine and Petroleum Geology, v. 26, p. 1785-1798.

Martin, J. B., Gieskes, J. M., Torres, M., and Kastner, M., 1993, Bromine and iodine in Peru margin sediments and pore fluids: Implications for fluid origins: Geochimica et Cosmochimica Acta, v. 57 , p. 4377-4389.

Martinelli, G., and Dadomo, A., 2005, Volcano monitoring and seismic events, in Mud Volcanoes, in Martinelli, G., and Panahi, B., eds., Geodynamics and Seismicity, NATO Sci. Ser. Earth Environ., 51,, Springer, New York, p. 211-220. 
Martinelli, M., Cremonini, S., and Samonati, E., 2012, Geological and geochemical setting of natural hydrocarbon emissions in Italy: In: Advances in natural gas technology, InTech e Open Access Publisher, RIJEKA, p. 79-120.

Martinis, B., 1962, Manifestazioni petrolifere, in Colombo, C., ed., Enciclopedia del petrolio e del gas naturale: Roma, p. 1251-1265.

Mascle, J., Mary, F., Praeg, D., Brosolo, L., Camera, L., Ceramicola, S., and Dupré, S., 2014, Distribution and geological control of mud volcanoes and other fluid/free gas seepage features in the Mediterranean Sea and nearby Gulf of Cadiz: Geo-Marine Letters, v. 34, p. 89-110.

Mau, S., Rehder, G., Arroyo, I. G., Gossler, J., and Suess, E., 2007, Indications of a link between seismotectonics and $\mathrm{CH} 4$ release from seeps off Costa Rica: Geochemistry, Geophysics, Geosystems, v. 8, p. 1-13.

Mazurenko, L. L., Soloviev, V. A., Belenkaya, I., Ivanov, M. K., and Pinheiro, L. M., 2002, Mud volcano gas hydrates at the Gulf of Cadiz: Terra Nova, v. 14, p. 321-329.

Mazzini, A., 2009, Mud volcanism: Processes and implications: Marine and Petroleum Geology, v. 26, p. $1677-1680$.

Mazzini, A., Etiope, G., and Svensen, H., 2012, A new hydrothermal scenario for the 2006 Lusi eruption, Indonesia. Insights from gas geochemistry: Earth and Planetary Science Letters, v. 317, p. 305-318.

Mazzini, A., Hadi, S., Etiope, G., and Inguaggiato, S., 2014, Tectonic Control of Piercement Structures in Central Java, Indonesia.: American Geophysical Union, Fall Meeting 2014, abstract \#OS21B-1138, v. \#OS21B-1138.

Mazzini, A., Ivanov, M. K., Nermoen, A., Bahr, A., Bohrmann, G., Svensen, H., and Planke, S., 2008, Complex plumbing systems in the near subsurface: Geometries of authigenic carbonates from Dolgovskoy Mound (Black Sea) constrained by analogue experiments: Marine and Petroleum Geology, v. 25, p. 457-472.

Mazzini, A., Ivanov, M. K., Parnell, J., Stadnitskaia, A., Cronin, B. T., Poludetkina, E., Mazurenko, L., and van Weering, T. C. E., 2004, Methane-related authigenic carbonates from the Black Sea: geochemical characterisation and relation to seeping fluids: Marine Geology, v. 212, p. 153181.

Mazzini, A., Nermoen, A., Krotkiewski, M., Podladchikov, Y., Planke, S., and Svensen, H., 2009a, Strike-slip faulting as a trigger mechanism for overpressure release through piercement structures. Implications for the Lusi mud volcano, Indonesia: Marine and Petroleum Geology, v. 26, p. 1751-1765.

Mazzini, A., Svensen, H., Akhmanov, G. G., Aloisi, G., Planke, S., Malthe-Sorenssen, A., and Istadi, B., 2007, Triggering and dynamic evolution of the LUSI mud volcano, Indonesia: Earth and Planetary Science Letters, v. 261, p. 375-388.

Mazzini, A., Svensen, H., Etiope, G., Onderdonk, N., and Banks, D., 2011, Fluid origin, gas fluxes and plumbing system in the sediment-hosted Salton Sea Geothermal System (California, USA): Journal of volcanology and geothermal research, v. 205, p. 67-83.

Mazzini, A., Svensen, H., Planke, S., Guliyev, I., Akhmanov, G. G., Fallik, T., and Banks, D., 2009b, When mud volcanoes sleep: Insight from seep geochemistry at the Dashgil mud volcano, Azerbaijan: Marine and Petroleum Geology, v. 26, p. 1704-1715.

Mazzini, A., Svensen, H. H., Planke, S., Forsberg, C. F., and Tjelta, T. I., 2016, Pockmarks and methanogenic carbonates above the giant Troll gas field in the Norwegian North Sea: Marine Geology, v. 373, p. 26-38.

McGowan, E., 2009, Spatial distribution of putative water related features in Southern Acidalia/Cydonia Mensae, Mars: Icarus, v. 202, p. 78-89.

McGowan, E. M., and McGill, G. E., 2010, The Utopia/Isidis overlap; Possible conduit for mud volcanism.: Lunar Planet. Sci. 41. Abstract 1070. 
Mellors, R., Kilb, D., Aliyev, A., Gasanov, A., and Yetirmishli, G., 2007, Correlations between earthquakes and large mud volcano eruptions: Journal of Geophysical Research, v. 112, p. B04304.

Métivier, L., de Viron, O., Conrad, C. P., Renault, S., Diament, M., and Patau, G., 2009, Evidence of earthquake triggering by the solid earth tides: Earth and Planetary Science Letters, v. 278, p. 370-375.

Michaelis, W., et al., 2002, Microbial reefs in the Black Sea fueled by anaerobic oxidation of methane: Science, v. 297, p. 1013-1015.

Milkov, A. V., 2000, Worldwide distribution of submarine mud volcanoes and associated gas hydrates: Marine Geology, v. 167, p. 29-42.

Milkov, A. V., and Dzou, L., 2007, Geochemical evidence of secondary microbial methane from very slight biodegradation of undersaturated oils in a deep hot reservoir: Geology, v. 35, p. 455458.

Milkov, A. V., Sassen, R., Apanasovich, T. V., and Dadashev, F. G., 2003, Global gas flux from mud volcanoes: A significant source of fossil methane in the atmosphere and the ocean: Geophysical Research Letters, v. 30, p. 1037, doi:1010.1029/2002GL016358.

Miller, S. A., Cristiano, C., Chiaraluce, L., Cocco, M., Barchi, M., and Kaus, B. J. P., 2004, Aftershocks driven by a high-pressure $\mathrm{CO} 2$ source at depth: Nature, v. 427, p. 724-727.

Motyka, R. J., Poreda, R. J., and Jeffrey, A. W. A., 1989, Geochemistry, Isotopic Composition, and Origin of Fluids Emanating from Mud Volcanos in the Copper River Basin, Alaska: Geochimica et Cosmochimica Acta, v. 53, p. 29-41.

Mukhtarov, A. S. h., Kadirov, F. A., Guliyev, I. S., Feyzullayev, A., and Lerche, I., 2003, Temperature Evolution in the Lokbatan Mud Volcano Crater (Azerbaijan) after the Eruption of 25 October 2001: Energy Exploration \& Exploitation, v. 21, p. 187-207.

Mumma, M. J., Villanueva, G. L., Novak, R. E., Hewagama, T., Bonev, B. P., DiSanti, M. A., Mandell, A. M., and Smith, M. D., 2009, Strong Release of Methane on Mars in Northern Summer 2003: Science, v. 323, p. 1041-1045.

Murton, B. J., and Biggs, J., 2003, Numerical modelling of mud volcanoes and their flows using constraints from the Gulf of Cadiz: Marine Geology, v. 195, p. 223-236.

Nadirov, R. S., Bagirov, E., and Tagiyev, M., 1997, Flexural plate subsidence, sedimentation rates, and structural development of the super-deep South Caspian Basin: Marine \& Petroleum Geology, v. 14, p. 383-400.

Naehr, T. H., Rodriguez, N. M., Bohrmann, G., Paull, C. K., and Botz, R., 2000, Methane-derived authigenic carbonates associated with gas hydrate decomposition and fluid venting above the Blake Ridge Diapir, in Paull, C. K., Matsumoto, R., Wallace, P. J., and Dillon, W. P., eds., Proc. ODP Scientific Results, Volume 164, College Station, TX (Ocean Drilling Program), p. 286-300.

Nakamukae, M., Haraguchi, T., Nakata, M., Ozono, S., Tajika, J., Ishimaru, S., Fukuzumi, T., and Inoue, M., 2004, Reactivation of the Niikappu mud volcano following the Tokachi-oki earthquake in 2003: Japan Earth and PLanetary Science 2004 Joint meeting, Chiba, Japan.

Nermoen, A., Galland, O., Jettestuen, E., Fristad, K., Podladchikov, Y., Svensen, H., and MaltheSørenssen, A., 2010, Experimental and analytic modeling of piercement structures: Journal of Geophysical Research: Solid Earth, v. 115, p. n/a-n/a.

O'Neill, 2016, Terrifying mud volcano eruption throws gigantic 4-metre 'earthquake fish' out of water: Mirror, v. http://www.mirror.co.uk/news/world-news/terrifying-mud-volcanoeruption-throws-7859960.

Oehler, D. Z., and Allen, C. C., 2010, Evidence for pervasive mud volcanism in Acidalia Planitia, Mars: Icarus, v. 208, p. 636-657.

Oehler, D. Z., and Allen, C. C., . 2009, Mud volcanoes in the martian lowlands: Potential windows to fluid-rich samples from depth. : 40th Lunar Planet. Sci. XL Abstract 1034. 
Okubo, C. H., 2016, Morphologic evidence of subsurface sediment mobilization and mud volcanism in Candor and Coprates Chasmata, Valles Marineris, Mars: Icarus, v. (in press).

Olu, K., Lance, S., Sibuet, M., Henry, P., Fiala-Medioni, A., and Dinet, A., 1997, Cold seep communities as indicators of fluid expulsion patterns through mud volcanoes seaward of the Barbados accretionary prism: Deep Sea Research, v. 44, p. 811-842.

Onderdonk, N., Mazzini, A., Shafer, L., and Svensen, H., 2011, Controls on the geomorphic expression and evolution of gryphons, pools, and caldera features at hydrothermal seeps in the Salton Sea Geothermal Field, southern California: Geomorphology, v. 130, p. 327-342.

Oppo, D., Capozzi, R., Nigarov, A., and Esenov, P., 2014, Mud volcanism and fluid geochemistry in the Cheleken peninsula, western Turkmenistan: Marine and Petroleum Geology, v. 57, p. 122134.

Orange, D. L., Teas, P. A. D., J., Baillie, P., and Johnstone, T., 2009, Using SeaSeep Surveys to Identify and Sample Natural Hydrocarbon Seeps in Offshore Frontier Basins: PROCEEDINGS OF THE ANNUAL CONVENTION - INDONESIAN PETROLEUM ASSOCIATION, ; , v. 33, p. 363-384

Pallasser, R. J., 2000, Recognising biodegradation in gas/oil accumulations through the d13C compositions of gas components: Organic Geochemistry, v. 31, p. 1363-1373.

Pinheiro, L. M., et al., 2003, Mud volcanism in the Gulf of Cadiz: results from the TTR-10 cruise: Marine Geology, v. 195, p. 131-151.

Planke, S., Svensen, H., Hovland, M., Banks, D., and Jamtveit, B., 2003, Mud and fluid migration in active mud volcanoes in Azerbaijan: Geo-Marine Letters, v. 23, p. 258-268.

Pondrelli, M., Rossi, A. P., Ori, G. G., van Gasselt, S., Praeg, D., and Ceramicola, S., 2011, Mud volcanoes in the geologic record of Mars: The case of Firsoff crater: Earth and Planetary Science Letters, v. 304, p. 511-519.

Poort, J., et al., 2012, Thermal anomalies associated with shallow gas hydrates in the K-2 mud volcano, Lake Baikal: Geo-Marine Letters, v. 32, p. 407-417.

Praeg, D., Ceramicola, S., Barbieri, R., Unnithan, V., and Wardell, N., 2009, Tectonically-driven mud volcanism since the late Pliocene on the Calabrian accretionary prism, central Mediterranean Sea: Marine and Petroleum Geology, v. this issue.

Revil, A., 2002, Genesis of mud volcanoes in sedimentary basins: A solitary wave-based mechanism: Geophys. Res. Lett., v. 29 (12), doi:10.1029/2001GL014465, 2002.

Rhakmanov, R. R., 1987, Mud Volcanoes and Their Importance in Forecasting of Subsurface Petroleum Potential: Nedra, Moscow, v. Moscow (in Russian).

Rodriguez, J. A. P., et al., 2007, Formation and disruption of aquifers in southwestern Chryse Planitia, Mars: Icarus, v. 191, p. 545-567.

Rudolph, M. L., Karlstrom, L., and Manga, M., 2011, A prediction of the longevity of the Lusi mud eruption, Indonesia: Earth and Planetary Science Letters, v. 308, p. 124-130.

Scholz, F., Hensen, C., Lu, Z., and Fehn, U., 2010, Controls on the 1291/I ratio of deep-seated marine interstitial fluids: 'Old' organic versus fissiogenic 129-iodine: Earth and Planetary Science Letters, v. 294, p. 27-36.

Scholz, F., Hensen, C., Reitz, A., Romer, R. L., Liebetrau, V., Meixner, A., Weise, S. M., and Haeckel, M., 2009, Isotopic evidence (87Sr/86Sr, [delta]7Li) for alteration of the oceanic crust at deep-rooted mud volcanoes in the Gulf of Cadiz, NE Atlantic Ocean: Geochimica et Cosmochimica Acta, v. 73, p. 5444-5459.

Shakirov, R., Obzhirov, A., Suess, E., Salyuk, A., and Biebow, N., 2004, Mud volcanoes and gas vents in the Okhotsk Sea area: Geo-Marine Letters, v. 24, p. 140-149.

Shnyukov, E. F., Sobolevskiy, Y. V., Gnatenko, G. I., Naumenko, P. I., and Kutniy, V. A., 1986, Mud volcanoes of Kerch-Taman region: Kiev: Naukova Dumka, p. 152 (in Russian)

Sil, S., and Freymueller, J. T., 2006, Well water level changes in Fairbanks, Alaska, due to the great Sumatra-Andaman earthquake: Earth Planets Space, v. 58, p. 181-184.

Skinner, J. A., and Mazzini, A., 2009, Martian mud volcanism: Terrestrial analogs and implications for formational scenarios: Marine and Petroleum Geology, v. 26, p. 1866-1878. 
Skinner, J. A., and Tanaka, K. L., 2007, Evidence for and implications of sedimentary diapirism and mud volcanism in the southern Utopia highland-lowland boundary plain, Mars: Icarus, v. 186, p. 41-59.

Sobissevitch, A. L., Gorbatikov, A. V., and Ovsuchenko, A. N., 2008, Deep Structure of the Mt. Karabetov Mud Volcano: Doklady Earth Sciences, v. 422, p. 1181-1185.

Sun, W.-L., Lin, L.-H., and Wang, P.-L., 2012, Salinity and Temperature Constraints on Microbial Methanogenesis in the Lei-Gong-Huo Mud Volcano of Eastern Taiwan: AGU 2012, v. B31D0445.

Svensen, H., Hammer, Ø., Mazzini, A., Onderdonk, N., Polteau, S., Planke, S., and Podladchikov, Y. Y., 2009a, Dynamics of hydrothermal seeps from the Salton Sea geothermal system (California, USA) constrained by temperature monitoring and time series analysis: Journal of Geophysical Research (Solid Earth), v. 114, B09201, doi:10.1029/2008JB006247.

Svensen, H., Planke, S., Chevallier, L., Malthe-Sørenssen, A., Corfu, F., and Jamtveit, B., 2007, Hydrothermal venting of greenhouse gases triggering Early Jurassic global warming: Earth and Planetary Science Letters, v. 256, p. 554-566.

Svensen, H., Planke, S., Malthe-Sørenssen, A., Jamtveit, B., Myklebust, R., Eidem, T., and Rey, S. S., 2004, Release of methane from a volcanic basin as a mechanism for initial Eocene global warming: Nature, v. 429 , p. 542-545.

Svensen, H., Planke, S., Polozov, A. G., Schmidbauer, N., Corfu, F., Podladchikov, Y. Y., and Jamtveit, B., 2009b, Siberian gas venting and the end-Permian environmental crisis: Earth and Planetary Science Letters, v. 277, p. 490-500.

Tanaka, K. L., 1997, Sedimentary history and mass flow structures of Chryse and Acidalia Planitiae, Mars: Journal of Geophysical Research-Planets, v. 102, p. 4131-4149.

Tanaka, K. L., 2005, Geology and insolation-driven climatic history of Amazonian north polar materials on Mars: Nature, v. 437, p. 991-994.

Tanaka, K. L., Carr, M. H., Skinner, J. A., Gilmore, M. S., and Hare, T. M., 2003, Geology of the MER 2003 "Elysium" candidate landing site in southeastern Utopia Planitia, Mars: Journal of Geophysical Research-Planets, v. 108.

Tanaka, K. L., Joyal, T., and Wenker, A., 2000, The Isidis Plains Unit, Mars: Possible catastrophic origin, tectonic tilting, and sediment loading. : Lunar Planet. Sci. XXXI. Abstract 2023.

Tanaka, K. L., Rodriguez, J. A. P., Skinner, J. A., Bourke, M. C., Fortezzo, C. M., Herkenhoff, K. E., Kolb, E. J., and Okubo, C. H., 2008, North polar region of Mars: Advances in stratigraphy, structure, and erosional modification: Icarus, v. 196, p. 318-358.

Tanaka, S., Ohtake, M., and Sato, H., 2004, Tidal triggering of earthquakes in Japan related to the regional tectonic stress: Earth, Planets and Space, v. 56, p. 511-515.

Tinivella, U., and Giustianiani, M., 2012, An Overview of Mud Volcanoes Associated to Gas Hydrate System, in Nemeth, K., ed., Earth and Planetary Sciences " "Updates in Volcanology - New Advances in Understanding Volcanic Systems", ISBN 978-953-51-0915-0.

Tsunogai, U., Maegawa, K., Sato, S., Komatsu, D. D., Nakagawa, F., Toki, T., and Ashi, J., 2012, Coseimic massive methane release from a submarine mud volcano: Earth and Planetary Science Letters, v. 341-344, p. 79-85.

TTR Program Global Database, http://folk.uio.no/adrianom/TTR\%20WWW/TTR/index.html.

Valentine, D. L., and Reeburgh, W. S., 2000, New perspectives on anaerobic methane oxidation: Environmental Microbiology, v. 2, p. 477-484.

Van Rensbergen, P., Depreiter, D., Pannemans, B., and Henriet, J.-P., 2004, Seafloor expression of sediment extrusion and intrusion at the El Arraiche mud volcano field, Gulf of Cadiz: Journal of Geophysical Research, v. 110, p. 1-13.

Viola, G., Andreoli, M., Ben-Avraham, Z., Stengel, I., and Reshef, M., 2005, Offshore mud volcanoes and onland faulting in southwestern Africa: neotectonic implications and constraints on the regional stress field: Earth and Planetary Science Letters, v. 231, p. 147-160. 
Walter, T. R., and Amelung, F., 2007, Volcanic eruptions following $M \geq 9$ megathrust earthquakes: Implications for the Sumatra-Andaman volcanoes: Geology, v. 35, p. 539-542.

Welhan, J. A., and Lupton, J. E., 1987, Light-Hydrocarbon Gases in Guaymas Basin Hydrothermal Fluids - Thermogenic Versus Abiogenic Origin: Aapg Bulletin-American Association of Petroleum Geologists, v. 71, p. 215-223.

West, M., Sanchez, J. J., and McNutt, A. R., 2005, Periodically Triggered Seismicity at Mount Wrangell, Alaska, After the Sumatra Earthquake Science, v. 308, p. 1144 - 1146.

Whiticar, M. J., 1999, Carbon and hydrogen isotope systematics of bacterial formation and oxidation of methane: Chemical Geology, v. 161, p. 291-314.

Woodside, J., Ivanov, M., Limonov, A. F., and Expeditions, S. S. o. t. A., 1998, Shallow gas and gas hydrates in the Anaximander Mountains region, Eastern Mediterranean Sea. In: Henriet JP,Mienert J (Eds) Gas hydrates: relevance to world margin stability and climate change: Geological society of London, v. 137, p. 177-193.

Woodside, J., Ivanov, M. K., and Limonov, A. F., 1997, Neotectonics and fluid flow through seafloor sediments in the Eastern Mediterranean and Black Sea., Technical series Intergovernmental Oceanographic Commission, Volume 48, p. 226.

Woodside, J. M., Mascle, J., Zitter, T. A. C., Limonov, A. F., Ergün, M., and Volkonskaia, A., 2002, The Florence Rise, the Western Bend of the Cyprus Arc: Marine Geology, v. 185, p. 177-194.

Worden, R. H., 1996, Controls on halogen concentrations in sedimentary formation waters: Mineral Mag, v. 60, p. 259-274.

Wrede, C., et al., 2012, Aerobic and anaerobic methane oxidation in terrestrial mud volcanoes in the Northern Apennines: Sedimentary Geology, v. 263, p. 210-219.

Yakimov, M., Giuliano, L., Crisafi, E., Chernikova, T., Timmis, K., and Golyshin, P., 2002, Microbial community of a saline mud volcano at San Biagio-Belpasso, Mt. Etna (Italy) Environmental Microbiology, v. 4, p. 249-256.

Yang, T. F., Yeh, G. H., Fu, C. C., Wang, C. C., Lan, T. F., Lee, H. F., Chen, C. H., Walia, V., and Sung, Q. C., 2004, Composition and exhalation flux of gases from mud volcanoes in Taiwan: Environmental Geology, v. 46, p. 1003-1011.

Yarushina, V. M., Podladchikov, Y. Y., and Connolly, J. A. D., 2015, (De)compaction of porous viscoelastoplastic media: Solitary porosity waves: Journal of Geophysical Research-Solid Earth, v. 120, p. 4843-4862.

Yusifov, M., and Rabinowitz, P. D., 2004, Classification of mud volcanoes in the South Caspian Basin, offshore Azerbaijan: Marine and Petroleum Geology, v. 21, p. 965-975.

Zeyen, H., Pessel, M., Ledesert, B., Hebert, R., Bartier, D., Sabin, M., and Lallemant, S., 2011, 3D electrical resistivity imaging of the near-surface structure of mud-volcano vents: Tectonophysics, v. 509, p. 181-190.

Zhu, Y. N., Shi, B. Q., and Fang, C. B., 2000, The isotopic compositions of molecular nitrogen: implications on their origins in natural gas accumulations: Chemical Geology, v. 164, p. 321330.

Zitter, T. A. C., Huguen, C., and Woodside, J. M., 2005, Geology of mud volcanoes in the eastern Mediterranean from combined sidescan sonar and submersible surveys: Deep Sea Research Part I: Oceanographic Research Papers, v. 52, p. 457-475.

Zoporowski, A., and Miller, S. A., 2009, Modelling eruption cycles and decay of mud volcanoes: Marine and Petroleum Geology, v. this issue. 
Fig. 1. (A) Conceptual drawing summarising the main elements characterising most MVs as well as main sources of fluids. (B) Example of tall erupting gryphon at the summit of Bakhar MV with intricate mud flows. (C) 2D high-resolution seismic image through the pie-shaped Mercator MV (left) and Buried MV (right) in the Gulf of Cadiz (courtesy of C. Berndt). Note the Christmas tree structures in the Buried MV. (D) Multibeam (Digital Terrain Model at $2 \mathrm{~m}$ ) through two "twin" mud cones within the Menes caldera (from Mascle et al., 2014). Note the plateau-like shape of the crater zone. (E) Combined multibeam bathimentry and sidescan sonal image from Bojardin MV, TTR-16 cruise, 2006 (from Akhmetzhanov et al., 2008). Note the circular moat formed around the subsiding flanks.

Fig.2. Overview of the main clusters of MVs distributed around the globe (modified and updated after: TTR Program Global Database; Milkov, 2000; Dimitrov, 2002; Kopf, 2002; Hensen et al., 2004; Shakirov et al., 2004; Kvenvolden and Rogers, 2005; Jerosch et al., 2006). Note that in our figure, we include the clusters of the structures that have been confirmed as MVs; however in the literature additional inferred structures may be mentioned although their attribution is uncertain (described as e.g. diapirs or phreatic springs with some mud, or not necessarily manifesting on the surface).

Fig. 3. Various morphologies of MVs: (A) conical, (B) elongated, (C) pie-shaped, (D) multicrater, (E) growing diapir-like, (F) stiff neck, $(\mathrm{G})$ swamp-like, $(\mathrm{H})$ plateau-like, (I) impact crater-like, (J) subsiding structure, (K) Subsiding flanks, (L) sink-hole type.

Fig. 4. Various morphologies and features present in MVs. (A) The Touragay MV, Azerbaijan, is one of the largest onshore MVs displaying a typical conical morphology with a 500m wide crater and a $\sim 4.5 \mathrm{~km}$ wide conical shape. (B) Napag MV, Iran, with a tall conical feature in its central part (90 m wide) surrounded a by a flat area where concentric collapse occurs (cfr. Fig. 5G). (C) Impact craterlike morphology for Bakhar satellite MV with gryphons and pools in its central part (D) Small conical gryphon ( $2 \mathrm{~m}$ in diameter) at the Salse di Puianello MV, Italy. Note the oil seepage. (E) Digity MV, Trinidad, consisting of a single gryphon of a few meters in height. (F) Swamp-like morphology for Palo Seco MV, Trinidad, with numerous interconnected pools and salsas inside the forest and with no substantial elevation. (G) Impact crater-like Morne Diablo MV, Trinidad, where the whole crater is occupied by a large lake. (H) Sink-hole type Naftliche MV, Iran, with a central crater (up to $150 \mathrm{~m}$ wide) hosting a lake where gas and water seepages occur. (I) Salse di Nirano MV, Italy, with numerous gryphons and pools erupting fluids and mud inside a subcircular depression. (J) Bulganak MV, Crimea, with numerous scattered pools in a gently depressing crater. 
Fig. 5. Combined DEM data and Quickbird satellite images of some of the MVs described herein. (A) Impact crater-like Bakhar satellite MV (Azerbaijan): A distinct internal crater can be observed in the centre of the low elevation feature. The remarkably deep crater highlights the explosive nature of the most recent eruption and the consequent collapse. (B) Multicrater Bakhar MV (Azerbaijan): Clusters of pools and gryphons are present throughout the feature. A clear crater cannot be distinguished since the eruptive activity of the volcano was not focused on a single location. (C) Growing diapir-like Koturdag MV (Azerbaijan) with conical shape and different overlapping mud breccia flows distributing radially from the central crater. The crater diapiric expulsion of mud breccia from the crater forms a tongue that extends towards the northern part of the volcano. (D) Elongated Lokbatan MV (Azerbaijan) with the most recent mud flow extending west (darker coloured mud breccia). An elongated graben frames the mud flow. Hundreds of extraction wells surround the MV. (E) Pieshaped Dashgil MV (Azerbaijan) with mud breccia flows that extend predominantly towards the east following the dipping of the terrain. The crater can be seen on the western side of the structure. $(\mathrm{F})$ Circular shaped Shongar MV (Azerbaijan) with a well-defined crater on its central part and numerous mud flows distributed concentrically. (G) Napag MV (Iran), with concentric collapse rings (yellow dashed lines) and a central elevated zone. The darkest coloured mud breccia flows towards the southwest, were erupted after the 2003 Bam earthquake. (H) Subsisding Gharniarigh MV (Iran) with a central island inside the crater.

Figure 6. Various examples of gryphons from several MVs. (A) Gryphon field in Dashgil MV crater. Man for scale inside the field. (B) Large gryphon resulting from the merging of several confining gryphons. Inside the gryphon up to 15 different bubbling spots were observed. (C) Tall gryphon (mud cone) on Bakhar MV. The structure reaches $10 \mathrm{~m}$ in height (man for scale on the left side of the gryphon). (D-E) Craters of gryphons where oily fluids and methane are continuously seeping with the low viscosity mud. This periodically overflows on the flanks of the structures. (F) Large bubbles formed in a $1 \mathrm{~m}$ wide gryphon of Dashgil MV. The high viscosity mud contains mud breccia clasts visible also on the bubble rim before the bursting. (G) Top view of a splatter gryphon. From the void conduit bursts of mud are intermittently ejected.

Fig. 7. Top: cartoon of simplified morphological evolution of a gryphon. A) section of a gryphon during its normal activity. B) the upper part of the gryphon's conduit is occluded and a new lateral pathway is reached on the flank of the gryphon. C) The new gryphon grows and incorporates the original one. Bottom: section of several types of gryphons described.

Fig. 8. Examples of pools generally occurring on the outskirts of the gryphon sites. (A) $1 \mathrm{~m}$ wide bubbling pool situated on the northern outskirts of Dashgil MV crater. Note the smaller pool to the left where almost exclusively oily fluids are seeping. (B) Oil- and iron-rich pool in a field of water- 
dominated pools. (C-D) Most pools have a circular shape and, despite their small elevation, mimic miniature caldera-like features where fluids are bubbling. (E) Irregular-shaped small pool seeping oily fluids. (F) Small pool seeping at the periphery of salsa A in Dashgil MV. (G) Newly formed small pool seeping water and gas. Only a small amount of grey mud is expelled that clearly differentiates from the surface oxidised brownish mud that surrounds the pool.

Fig. 9. Examples of salsa lakes at MV sites. (A-B) salsa lake in Dashgil MV during dry (A) and wet (B) season. (C) Large salsa in the crater of Garadag MV (D) Large salsa in Ain MV. (E-F) Detail of gas vented out at salsa lakes.

Fig. 10. Examples of sinter features at MV sites. (A) Sinter cones on the south eastern part of Dashgil MV (cfr. Fig. 3 in Mazzini et al., 2009b). These cones are interpreted as former gryphons. (B-C-D) detail of sintered mud breccia showing molten mud (C) and clasts in their internal structure (D). (E) Image of Koturdag MV crater. During the most recent eruption, burning methane occurred at the contact between the crater and the extruded dense mud breccia. This resulted in sinter striations of cooked mud breccia that indicate the synchronous burning and extrusion. (F) Detail of sinter striations in Koturdag MV. (G) Panoramic view of Lokbatan MV crater (see men for scale). The reddish coloured zone represents the crater sinter zone where methane continued to burn after the October 2001 eruption. Note the concentric collapse features rimming the crater are interpreted as evidence of the deflation of a shallow chamber. In the background are numerous oil wells that surround the MV. (H) Burning methane in Lokbatan MV observed in November 2002.

Fig. 11. Nine months of water and air temperature logging at one of the Dashgil salsa lakes. The two curves reveal a similar trend indicating the strong control of the air temperature over the large mass of water in the salsa lake.

Fig 12. (A) Methane stable carbon isotope composition versus methane/(ethane+propane) ratio for gas samples collected in different vents from four MVs in Azerbaijan (data reported in Supplementary Material, Table S1A). The small dots refer to MVs and other seeps from a global data-set (Etiope et al., 2009a; Etiope, 2015). M: Microbial; T: Thermogenic. The diagram shows molecular fractionation in the gas released from MVs compared to the original reservoir gas; gas released in peripheral vents are more fractionated than the gas in central craters (see text for explanations). (B) Stable $\mathrm{C}$ and $\mathrm{H}$ isotope composition of methane released from MV worldwide (from Etiope et al. 2009 and additions from Etiope et al. 2011b). $T_{O}$ : thermogenic with oil; $T_{C}$ : thermogenic with condensate; $T_{D}$ : dry thermogenic. (C) Relationship between $\delta{ }^{13} \mathrm{C}$ of $\mathrm{CO}_{2}$ and $\mathrm{CO}_{2}$ concentration in $\mathrm{MV}$ (from Etiope et al, 2009b), including the new Azerbajan MV data reported in this work. The two lines refer to a mixing trend similar to the model of Jeffrey et al (1991). (D) $\delta^{18} \mathrm{O}$ and $\delta \mathrm{D}$ of waters from MVs worldwide 
2590 (from Dia et al., 1999; Dählmann and de Lange, 2003; Lavrushin et al., 2005; Hensen et al., 2007 and 2591 refs therein) including the Azerbaijan new data (Table S1B) reported in this work. The present day 2592 global meteoric water line (GMWL) is also indicated. Note the values of the melt water from snow at 2593 the Koturdag summit and the Garadag sample after rain.

Fig. 13. Cartoon sketching the growth stages of a MV from its initial subsurface formation to final manifestation on the surface with eruption of mud breccia. During its growth towards the surface, the piercement structure collects the contribution of different fluids and eventual reservoirs at different stages (e.g. arrows). Modified after Mazzini (2009).

Fig. 14. Relationship between earthquake magnitude and the distance over which a variety of mud volcano responses have been documented. (A) Modified from Manga et. al., (2009) to include additional triggered responses from distant earthquakes on MV systems. The figure shows that several of these events appear well-above the Manga et al, (2009) empirical line and that instead the Delle Donne et al. (2010) threshold line appears more appropriate. (B) Satellite image of Pakistan and Iran (see countries inset map with indicated rectangle) showing the focal mechanisms of two large magnitude earthquakes occurred in the region and a newly formed mud island offshore of Gwadar. The M 7.8 normal faulting event did not trigger any documented geological response in the far field while the M 7.7 strike slip event promoted the formation of the new mud volcanic eruption forming the Gwadar Island. The red point indicates the geographic location of the newly formed mud island. Inset maps show the areal image of the island

2612 Fig. 15. Examples of microbial colonies at seepage sites. (A-B) Greenish-coloured microbial colonies 2613 thriving around the gryphon neck and along the fluids flow lines; (C) similar brownish colonies growing close to a poorly active pool; (D) dark brown microbial colony growing inside a small pool where oily (?) fluids (note the bubbles colour) constantly seep; (E) greyish foamy microbial colonies

2616 floating within a small oil seeping pool. Similar types of colonies have been observed also in the 2617 Salton Sea hydrothermal seeps; (F-G) extensive brownish colony growing on the edges of a large 2618 gryphon system; microbial colonies commonly grow at this location where the gas bubbling creates 2619 less turbulence; $(\mathrm{H})$ detail from image $\mathrm{G}$ showing microbubbles within the microbial colonies suggesting production of oxygen (?) during the thriving of the colonies. 
Adriano Mazzini ${ }^{1}$, Giuseppe Etiope ${ }^{2}$

${ }^{1}$ Centre for Earth Evolution and Dynamics, University of Oslo, Norway

$2628{ }^{2}$ Istituto Nazionale di Geofisica e Vulcanologia, Sezione Roma 2, Italy, and Faculty of Environmental Science and Engineering, Babes Bolyai University, Cluj-Napoca, Romania

\section{Methods}

Published material is complemented with new and unpublished data that form a substantial contribution to the observations reported herein. These data were collected mainly during fieldwork studies conducted in October 2002, September-October 2005 and January 2006. Particular efforts were focused on eleven MV structures (Dashgil, Bakhar, Bakhar Satellite, Keireki, Garadag, Lokbatan, Akhtarma Putinskaya, Kushkhana, Shongar, Pirekeshkul, Koturdag) situated in the region around Baku. Field mapping and observations were combined with in situ temperature measurements and sampling of seeping fluids. Detailed GPS measurements were taken using a Thales Mobile Mapper used as a rover system combined with a Thales reference station for positioning correction. The reported heights represent absolute values and do not consider the negative elevation of the Caspian Sea (i.e. $-29 \mathrm{~m} \mathrm{bsl)}$. The reported historical record of the eruptions refers to Aliyev et al. (2002) and it is updated with most recent events. Quickbird satellite images with RGB true colour view and $0.5 \mathrm{~m}$ resolution were acquired during January 2006 over the Cape Alyat peninsula and the Lokbatan region.

2645 Temperature measurements were taken with a hand held TFX 392 SK-5 thermometer with a precision of $0.1{ }^{\circ} \mathrm{C}$. Temperature monitoring of one of the salsa lakes in Dashgil MV was acquired during the period 11-10-2005 to 12-07-2006. For this monitoring, StowAway TidbiT loggers were used, operating in the -20 to $+70{ }^{\circ} \mathrm{C}$ range, with a reported accuracy of $0.20^{\circ} \mathrm{C}$, a resolution of $0.16{ }^{\circ} \mathrm{C}$ (both at $20{ }^{\circ} \mathrm{C}$ ), and a response time of $\sim 5$ minutes. All loggers were programmed for temperature measurements every 4 th minute. The logger in the salsa lake was deployed at $\sim 4 \mathrm{~m}$ depth. The total number of individual measurements is 21763. Air temperature and humidity was measured simultaneously at one location in the immediate vicinity of the seeps, using a HOBO Pro RH/Temp logger, mounted on a monitoring float in the centre of the salsa lake. Methane seepage was detected using a Drager Pac Ex2 Methane sniffer (lower detection limit of 0.1\%). The density of expelled mud and waters were measured by a commercial electronic scale, with accuracy greater than $\sim 2 \%$ for the relevant mass of the measured samples. (2009b). 
Table S1A. Molecular and isotopic composition analyses of gas emitted at different locations. Well data from from Katz et al. (2002).

\begin{tabular}{|c|c|c|c|c|c|c|c|c|c|c|c|c|c|c|c|c|c|c|}
\hline \multirow[t]{2}{*}{ Sample ID } & \multirow[t]{2}{*}{ MV structure } & \multirow[t]{2}{*}{ Comments } & \multicolumn{7}{|l|}{ Vol \% } & \multirow[b]{2}{*}{$\mathrm{CO}_{2}$} & \multicolumn{8}{|c|}{$\delta^{13} \mathrm{C} \%_{0}$ (VPDB) } \\
\hline & & & $\underline{\mathrm{C}_{1}}$ & $\mathrm{C}_{2}$ & $\mathrm{C}_{3}$ & $i \mathrm{C}_{4}$ & $n \mathrm{C}_{4}$ & $i \mathrm{C}_{5}$ & $n \mathrm{C}_{5}$ & & $\mathrm{C}_{1}$ & $\mathrm{C}_{2}$ & $\mathrm{C}_{3}$ & $i \mathrm{C}_{4}$ & $n \mathrm{C}_{4}$ & $i \mathrm{C}_{5}$ & $n \mathrm{C}_{5}$ & $\mathrm{CO}_{2}$ \\
\hline AZ $05 \mathrm{~A}-21$ & Pirekeshkyul & Pool & 97.80 & 0.02 & & & & & & 2.18 & -38.9 & & & & & & & -17.4 \\
\hline AZ $05 \mathrm{~A}-24$ & Pirekeshkyul & Pool & 96.07 & 0.08 & & & & & & 3.86 & -43.1 & & & & & & & 7.1 \\
\hline AZ $05 \mathrm{~A}-23$ & Pirekeshkyul & Gryphon & 97.29 & 0.15 & & & & & & 2.56 & -42.0 & -24.8 & & & & & & 11.8 \\
\hline$A Z 05 A-32$ & Dashgil & Pool & 98.41 & 0.25 & & & & & & 1.34 & -41.6 & & & & & & & -12.1 \\
\hline AZ $05 \mathrm{~A}-33$ & Dashgil & Pool & 98.69 & 0.24 & & & & & & 1.07 & -40.8 & -24.9 & & & & & & 3.2 \\
\hline AZ $05 \mathrm{~A}-46$ & Dashgil & Pool & 99.58 & 0.01 & & & & & & 0.40 & -41.1 & & & & & & & -17.2 \\
\hline AZ $05 \mathrm{~A}-47$ & Dashgil & Pool & 99.63 & 0.01 & & & & & & 0.36 & -40.9 & & & & & & & -19.4 \\
\hline AZ 06A-05 & Dashgil & Pool & 99.02 & 0.18 & & & & & & 0.79 & -41.8 & -24.4 & & & & & & 2.0 \\
\hline AZ 06A-07 & Dashgil & Pool & 99.19 & 0.37 & & & & & & 0.43 & -42.1 & -25.9 & & & & & & 1.9 \\
\hline AZ 06A-08 & Dashgil & Pool & 98.96 & 0.15 & & & & & & 0.88 & -43.9 & -26.6 & & & & & & -8.2 \\
\hline$A Z 05 A-30$ & Dashgil & Pool near salsa A & 99.61 & 0.11 & & & & & & 0.28 & -40.4 & -30.4 & & & & & & -13.1 \\
\hline AZ 06A-15 & Dashgil & Gryphon & 99.35 & 0.07 & & & & & & 0.58 & -43.2 & -26.4 & & & & & & -12.2 \\
\hline AZ 06A-16 & Dashgil & Gryphon & 94.87 & 0.04 & & & & & & 5.08 & -35.2 & & & & & & & -17.0 \\
\hline AZ 05A-31 & Dashgil & Gryphon & 99.33 & 0.12 & & & & & & 0.55 & -42.3 & -25.7 & & & & & & -6.8 \\
\hline AZ 05A-29 & Dashgil & Salsa B & 99.65 & 0.01 & & & & & & 0.34 & -41.6 & & & & & & & -23.5 \\
\hline & & & & & & & & & & & & & & & & & & \\
\hline AZ 06A-09 & Bakhar & Pool/smal 1 gryph & 98.17 & 0.07 & & & & & & 1.76 & -48.6 & -26.0 & & & & & & 2.5 \\
\hline AZ 06A-10 & Bakhar & Small gryph & 98.73 & 0.09 & & & & & & 1.18 & -48.7 & -26.9 & & & & & & 7.5 \\
\hline AZ $06 \mathrm{~A}-12$ & Bakhar & Pool & 99.74 & 0.00 & & & & & & 0.26 & -46.8 & & & & & & & -16.9 \\
\hline AZ 06A-21 & Bakhar & Pool & 99.55 & 0.01 & & & & & & 0.44 & -45.6 & & & & & & & -9.4 \\
\hline AZ 06A-19 & Bakhar Sat & Pool & 99.29 & 0.01 & & & & & & 0.70 & -46.6 & & & & & & & -6.3 \\
\hline & & & & & & & & & & & & & & & & & & \\
\hline AZ 06A-25 & Koturdag & Small gryphon & 97.31 & 0.34 & & & & & & 2.36 & -50.9 & -30.5 & & & & & & 12.7 \\
\hline $\mathrm{AZ} 06 \mathrm{~A}-27$ & Koturdag & $\begin{array}{l}\text { Diapir-crater } \\
\text { contact }\end{array}$ & 90.52 & 2.48 & 0.40 & 0.34 & 0.18 & 0.22 & 0.07 & 5.80 & -50.4 & -28.3 & -23.2 & -28.9 & -23.3 & -27.6 & -21.3 & 7.5 \\
\hline Well N. & Reservoir & Depth (m) & & & & & & & & & & & & & & & & \\
\hline$\# 123$ & Bakhar & $3984-4051$ & 93.65 & 2.42 & 2.14 & 0.32 & 0.39 & 0.12 & 0.10 & 0.85 & -37.48 & -27 & & & & & & \\
\hline \#183 & Bakhar & 2839-2842 & 94.09 & 2.55 & 1.70 & 0.23 & 0.35 & 0.14 & 0.12 & 0.81 & -38.58 & -26.8 & & & & & & \\
\hline \#198 & Bakhar & $4238-4253$ & 94.75 & 2.62 & 1.33 & 0.22 & 0.34 & 0.14 & 0.13 & 0.46 & -38.97 & -27.8 & & & & & & \\
\hline$\# 208$ & Bakhar & $4348-4391$ & 95.88 & 2.76 & 0.78 & 0.16 & 0.22 & 0.06 & 0.05 & 0.08 & -40.09 & -27.4 & & & & & & \\
\hline \#238 & Bakhar & $4431-4443$ & 90.14 & 3.25 & 1.93 & 0.26 & 0.37 & 0.14 & 0.13 & 3.78 & -41.42 & -27.6 & & & & & & \\
\hline \#569 & Bulla Deniz & $5395-5422$ & 92.04 & 3.59 & 2.29 & 0.28 & 0.42 & 0.15 & 0.13 & 1.09 & -42.17 & -28 & & & & & & \\
\hline$\# 437$ & Duvanny & $4285-4295$ & 85.84 & 4.33 & 4.00 & 0.98 & 1.74 & 0.48 & 0.40 & 2.22 & -41.7 & -28.7 & & & & & & \\
\hline \#106 & Duvanny & $975-963$ & 97.20 & 2.49 & 0.02 & 0.02 & 0.00 & 0.00 & 0.00 & 0.28 & -44.3 & -26.7 & & & & & & 7.0 \\
\hline \#55 & Dashgil & $3625-3604$ & 95.40 & 2.61 & 1.08 & 0.19 & 0.17 & 0.19 & 0.10 & 0.27 & -49.0 & -31.1 & & & & & & -13.2 \\
\hline
\end{tabular}




\begin{tabular}{|c|c|c|c|c|c|c|c|c|c|c|c|c|c|c|c|c|c|c|c|c|c|c|}
\hline \multirow[t]{2}{*}{ Sample ID } & \multirow[t]{2}{*}{ MV structure } & \multirow[t]{2}{*}{ Comments } & \multicolumn{14}{|c|}{ ppm } & \multirow[b]{2}{*}{$\mathrm{ClNa}$} & \multirow[b]{2}{*}{$\mathrm{Cl} / \mathrm{Br}$} & \multirow[b]{2}{*}{$\mathrm{Na} / \mathrm{Br}$} & \multirow[b]{2}{*}{$\mathrm{Cl} / \mathrm{B}$} & \multicolumn{2}{|c|}{$\begin{array}{l}\text { Isotopes \% (V- } \\
\text { SMOW) }\end{array}$} \\
\hline & & & B & $\mathrm{Ca}$ & $\mathbf{K}$ & $\mathbf{L i}$ & Mg & $\mathrm{Na}$ & $\mathrm{Sr}$ & Ba & Mn & $\mathbf{F e}$ & Cl & $\mathrm{Br}$ & $\mathrm{SO}_{4}$ & $\mathbf{F}$ & & & & & $8^{18} \mathrm{O}^{*}$ & $\delta D^{*}$ \\
\hline AZ $05 \mathrm{~A}-01$ & Pirekeshkyul & Pool, no elevation, sustained gas seepage & 207 & 3 & 48 & 2 & 51 & 12470 & 1 & $<1$ & $<1$ & 2 & 10203 & 39 & 583 & 7 & 0.82 & 262.37 & 320.67 & 49.37 & 6.52 & -8 \\
\hline AZ $05 \mathrm{~A}-02$ & Pirekeshkyul & ol, no elevation, oil seepage & 103 & 14 & 17 & $<1$ & 43 & 5474 & 2 & $<1$ & $<1$ & $<1$ & 5232 & 21 & 24 & $<1$ & 0.96 & 248.89 & 260.42 & 50.74 & & \\
\hline AZ $05 \mathrm{~A}-20$ & Pirekeshkyul & $\begin{array}{l}\text { Pool, same as station AZ } 05 \mathrm{~A}-01 \text {, pulsations of } \\
\text { more vigorous seepage } 1 \text { min long, sampled day } \\
\text { after rain }\end{array}$ & 98 & 7 & 20 & 1 & 37 & 5977 & 1 & $<1$ & $<1$ & $<1$ & 3701 & 12 & 8 & $<1$ & 0.62 & 311.31 & 502.78 & 37.66 & & \\
\hline AZ $05 \mathrm{~A}-21$ & Pirekeshkyul & $\begin{array}{l}\text { Pool, same as station AZ } 05 A-02 \text {, sampled day after } \\
\text { rain }\end{array}$ & 121 & 8 & 19 & $<1$ & 33 & 7007 & $<1$ & $<1$ & $<1$ & $<1$ & 7334 & 22 & 490 & $<1$ & 1.05 & 333.54 & 318.69 & 60.70 & & \\
\hline $\mathrm{AZ} 05 \mathrm{~A}-22$ & Pirekeshkyul & $\begin{array}{l}\text { Gryphon, microbial colony framing, sampled day } \\
\text { after rain }\end{array}$ & 102 & 3 & 25 & $<1$ & 21 & 5250 & $<1$ & $<1$ & $<1$ & $<1$ & 3657 & 13 & 1236 & $<1$ & 0.70 & 270.95 & 388.96 & 35.85 & 8.59 & -13 \\
\hline $\mathrm{AZ} 05 \mathrm{~A}-22 \mathrm{~b}$ & Pirekeshkyul & $\begin{array}{l}\text { Pool with no elevation aside of gryphon AZ } 05 \mathrm{~A}-22 \text {, } \\
\text { oil seepage, microbial colony framing, sampled day } \\
\text { after rain }\end{array}$ & 125 & 5 & 13 & $<1$ & 34 & 6844 & 1 & $<1$ & $<1$ & $<1$ & 7912 & 34 & 48 & $<1$ & 1.16 & 234.41 & 202.79 & 63.18 & 5.21 & -24 \\
\hline$A Z 05 A-23$ & Pirekeshkyul & $\begin{array}{l}\text { Gryphon, elongated with } 3 \text { seepage points, brownish } \\
\text { biofilm locally observed on the edges }\end{array}$ & 86 & 6 & 22 & $<1$ & 45 & 5012 & 2 & 2 & $<1$ & $<1$ & 3004 & 3 & 15 & $<1$ & 0.60 & 971.52 & 1620.74 & 34.98 & 7.05 & -25 \\
\hline AZ $05 \mathrm{~A}-24$ & Pirekeshkyul & Pool with low elevation at the foot of a gryphon & 187 & 3 & 21 & $<1$ & 9 & 6176 & $<1$ & $<1$ & $<1$ & $<1$ & 4153 & 23 & 2078 & $<1$ & 0.67 & 82.08 & 270.81 & 22.16 & & \\
\hline $\mathrm{AZ} 05 \mathrm{~A}-25$ & Pirekeshkyul & $\begin{array}{l}\text { Gryphon, isolated on eastern side from gryphon } \\
\text { ridge }\end{array}$ & 77 & 7 & 13 & 1 & 26 & 3747 & 2 & 1 & $<1$ & $<1$ & 2597 & 3 & $<1$ & $<1$ & 0.69 & 1008.24 & 1454.57 & 33.53 & 7.62 & -27 \\
\hline AZ $05 \mathrm{~A}-27$ & Dashgil & $\begin{array}{l}\text { Salsa } 2 \text { (large), vigorous venting, two main seepage } \\
\text { point observed on central and eastern side }\end{array}$ & 69 & 293 & 30 & $<1$ & 299 & 8239 & 31 & $<1$ & $<1$ & $<1$ & 14383 & 53 & 58 & $<1$ & 1.75 & 269.36 & 154.30 & 207.62 & 3.30 & -16 \\
\hline AZ 05A-28 & Dashgil & $\begin{array}{l}\text { Gryphon, tall, isolated, high viscosity mud with oil } \\
\text { seepage, } 15 \text { seepage points observed }\end{array}$ & 75 & 15 & 24 & 2 & 48 & 5865 & 9 & 1 & $<1$ & $<1$ & 8739 & 40 & 90 & $<1$ & 1.49 & 215.77 & 144.81 & 116.65 & 5.94 & -24 \\
\hline AZ $05 \mathrm{~A}-29$ & shgil & Salsa 1 (monitored) & 87 & 75 & 9 & 1 & 587 & 16707 & 58 & 4 & $<1$ & $<1$ & 28458 & 96 & 125 & $<1$ & 1.70 & 96.70 & 174.18 & 328.53 & 3.70 & -4 \\
\hline AZ $05 \mathrm{~A}-30$ & Dashgil & $\begin{array}{l}\text { Pool, large, north of salsa } 2 \text {, high water content, two } \\
\text { seepage points }\end{array}$ & 512 & 949 & 162 & 5 & 2912 & 83357 & 97 & $<1$ & $<1$ & $<1$ & 101043 & 329 & 3571 & $<1$ & 1.21 & 07.42 & 253.61 & 197.48 & 2.90 & -37 \\
\hline$A Z 05 A-31$ & Dashgil & $\begin{array}{l}\text { Gryphon, northernmost in gryphon field, high } \\
\text { viscosity, oil seepage, large bubbles at two seepage } \\
\text { points (merge of two gryphons) }\end{array}$ & 112 & 14 & 29 & 2 & 54 & 6605 & 10 & 5 & $<1$ & $<1$ & 9613 & 42 & 99 & $<1$ & 1.46 & 230.12 & 158.12 & 85.98 & 5.80 & -27 \\
\hline$A Z 05 A-32$ & Dashgil & $\begin{array}{l}\text { Pool, aside of gryph } \\
\text { foamy microbial co }\end{array}$ & 175 & 38 & 32 & 2 & 234 & 11451 & 20 & $<1$ & $<1$ & $<1$ & 17108 & 76 & 1978 & $<1$ & 1.49 & 223.99 & 149.92 & 97.52 & 2.48 & -37 \\
\hline AZ $05 \mathrm{~A}-33$ & Dashgil & $\begin{array}{l}\text { Pool, s } \\
\text { suppos }\end{array}$ & 133 & 24 & 29 & 1 & 69 & 7544 & 10 & 6 & $<1$ & $<1$ & 11383 & 52 & 95 & $<1$ & 1.51 & 17.14 & 143.89 & 85.36 & & \\
\hline AZ 05A-34 & shgil & $\begin{array}{l}\text { Gryphon with one of the largest craters in Dashgil } \\
\text { MV. High vioscosity, microbial colonies locally } \\
\text { present on edges of crater }\end{array}$ & 165 & 12 & 39 & 3 & 72 & 9631 & 12 & 1 & $<1$ & $<1$ & 13955 & 71 & 317 & $<1$ & 1.45 & 197.32 & 136.18 & 84.70 & 3.88 & -27 \\
\hline $\mathrm{AZ} 05 \mathrm{~A}-46 \mathrm{~A}$ & Dashgil & $\begin{array}{l}\text { Pool, northeren part of crater, low viscosity } \\
\text { brownish mud with strong seepage }\end{array}$ & 47 & 428 & 27 & $<1$ & 297 & 9356 & 32 & 1 & $<1$ & $<1$ & 16015 & 59 & 312 & $<1$ & 1.71 & 73.61 & 159.85 & 339.78 & 1.77 & \\
\hline $\mathrm{AZ}$ 05A-46B & Dashgil & $\begin{array}{l}\text { Pool, close to AZ 05A-46A, black oil-rich fluids } \\
\text { seeping }\end{array}$ & 37 & 472 & 42 & $<1$ & 284 & 8187 & 32 & $<1$ & $<1$ & $<1$ & 14919 & 53 & 221 & $<1$ & 1.82 & 283.53 & 155.59 & 403.10 & 1.07 & -48 \\
\hline$A Z 05 A-47$ & Dashgil & Pool, close to AZ 05A-46A and AZ 05A-46B & 73 & 909 & 28 & 1 & 254 & 6904 & 17 & $<1$ & $<1$ & $<1$ & 11217 & 43 & 3999 & $<1$ & 1.62 & 62.20 & 161.39 & 153.13 & & \\
\hline AZ $05 \mathrm{~A}-41$ & Garadag & $\begin{array}{l}\text { Salsa lake inside the crater, large bubbles } \\
\text { occasionally observed, microbial colonies thriving } \\
\text { on localised zones }\end{array}$ & 323 & 5 & 16 & $<1$ & 32 & 6403 & 2 & 1 & $<1$ & $<1$ & 7026 & 32 & 251 & $<1$ & 1.10 & 8.17 & 198.84 & 21.74 & 7.34 & 85 \\
\hline AZ 05A-54 & Bakhar & $\begin{array}{l}\text { Gryphon, small gryphon on flank of larger gryphon, } \\
\text { episodically seeping water. Microbial colony } \\
\text { thriving along the flank }\end{array}$ & 169 & 6 & 24 & $<1$ & 18 & 9663 & 4 & 1 & $<1$ & $<1$ & 13434 & 62 & 514 & $<1$ & 1.39 & 218.07 & 156.86 & 79.26 & 5.73 & -37 \\
\hline AZ 06A-05 & shgil & Pool, northern part of gryphon field & 107 & 16 & 16 & 2 & 36 & 5348 & 5 & 2 & $<1$ & $<1$ & 664 & 29 & 123 & $<1$ & 1.30 & 41.03 & 185.11 & 5.14 & 4.45 & -43 \\
\hline AZ 06A-07 & shgil & $\begin{array}{l}\text { Pool on northern part of gryphon field, at the foot of } \\
\text { AZ } 06 \mathrm{~A}-06\end{array}$ & 212 & 68 & 27 & 1 & 120 & 9878 & 18 & $<1$ & $<1$ & $<1$ & 14669 & 70 & 722 & $<1$ & 1.48 & 8.94 & 140.70 & 69.04 & 3.09 & -15 \\
\hline AZ $06 \mathrm{~A}-08$ & Dashgil & $\begin{array}{l}\text { Pool on } \\
\text { a large }\end{array}$ & 199 & 349 & 51 & 2 & 388 & 15121 & 19 & $<1$ & $<1$ & $<1$ & 21018 & 97 & 5534 & $<1$ & 1.39 & 16.61 & 155.84 & 105.36 & 2.15 & -19 \\
\hline AZ 06A-15 & shgil & $\begin{array}{l}\text { Gryphon with low elevatio } \\
\text { large gryphons in the centr } \\
\text { seepage of gas }\end{array}$ & 185 & 35 & 26 & 1 & 114 & 9766 & 17 & 1 & $<1$ & $<1$ & 14467 & 66 & 254 & $<1$ & 1.48 & 17.88 & 147.08 & 78.07 & 5.20 & -13 \\
\hline$A Z 06 A-17$ & shgil & Salsa 2 (large) & 61 & 215 & 21 & $<1$ & 6 & 775 & 28 & 13 & 1 & $<1$ & 13340 & 45 & 14 & $<1$ & 1.72 & 4.27 & 1.51 & 216.94 & 25 & -11 \\
\hline AZ 06A-18 & Dashgil & $\begin{array}{l}\text { Salsa } 1 \text { (monitored), up to } 15-20 \mathrm{~cm} \text { thick microbial } \\
\text { mat was observed on one side of the salsa where the } \\
\text { water is shallower and the seepage activity less } \\
\text { effective }\end{array}$ & 75 & 393 & 30 & $<1$ & 493 & 14435 & 47 & 4 & $<1$ & $<1$ & 25464 & 86 & 111 & $<1$ & 1.76 & 294.57 & 166.98 & 338.78 & 1.35 & -22 \\
\hline AZ 06A-09 & Bakhar & $\begin{array}{l}\text { Pool on } \\
\text { elevatio }\end{array}$ & 97 & 15 & 12 & $<1$ & 13 & 5146 & 5 & 4 & $<1$ & $<1$ & 75 & 25 & 23 & 9 & 1.24 & 57.17 & 207.58 & 65.57 & 3.80 & -55 \\
\hline AZ 06A-10 & Bakhar & $\begin{array}{l}\text { Gryphon on the eastern part of the volcano with low } \\
\text { elevation and bacterial mat framing the seepage }\end{array}$ & 97 & 16 & 11 & $<1$ & 14 & 5262 & 5 & 4 & $<1$ & $<1$ & 6703 & 15 & $<1$ & $<1$ & 1.27 & 453.36 & 355.90 & 69.07 & 6.56 & -46 \\
\hline $\mathrm{AZ} 06 \mathrm{~A}-12$ & Bakhar & $\begin{array}{l}\text { Pool with low elevationon and intermitt } \\
\text { on northwestern part of the volcano }\end{array}$ & 260 & 6 & 32 & $<1$ & 89 & 16869 & 9 & 3 & $<1$ & $<1$ & 25820 & 83 & 285 & $<1$ & 1.53 & 310.58 & 202.90 & 99.49 & 2.95 & -54 \\
\hline $\mathrm{AZ} 06 \mathrm{~A}-12 \mathrm{~b}$ & Bakhar & Pool, close to station AZ 06A-12 & 180 & 6 & 24 & $<1$ & 39 & 11286 & 6 & 4 & $<1$ & $<1$ & 16634 & 58 & 85 & $<1$ & 1.47 & 285.73 & 193.87 & 92.22 & 1.74 & -44 \\
\hline $\mathrm{AZ} 06 \mathrm{~A}-21$ & thar & $\begin{array}{l}\text { Pool on north westernmost part of crater close to } \\
\text { active gryphon }\end{array}$ & 147 & 17 & 25 & $<1$ & 86 & 9548 & 7 & 2 & $<1$ & $<1$ & 14138 & 53 & 195 & $<1$ & 1.48 & 67.86 & 180.90 & 95.90 & 4.77 & -33 \\
\hline AZ 06A-19 & Bakhar Sat & $\begin{array}{l}\text { Pool with no levation and small size within a pools } \\
\text { field in the eastern side of the crater }\end{array}$ & 305 & 60 & 94 & 2 & 324 & 28469 & 24 & $<1$ & $<1$ & $<1$ & 45658 & 178 & 1445 & $<1$ & 1.60 & 256.28 & 159.80 & 149.88 & 1.98 & -44 \\
\hline AZ $06 \mathrm{~A}-20$ & har Sat & & 251 & 10 & 55 & 2 & 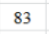 & 15618 & 10 & 17 & $<1$ & $<1$ & 24363 & 102 & 17 & $<1$ & 1.56 & 9.62 & 153.61 & 18 & 21 & -25 \\
\hline $\mathrm{AZ}$ 06A-25 & Koturdag & $\begin{array}{l}\text { Gryphon with low elevation and narrow void internal } \\
\text { conduit. }\end{array}$ & 65 & 14 & 25 & $<1$ & 104 & 6209 & 9 & 8 & $<1$ & $<1$ & 23 & 67 & 33 & $<1$ & 1.28 & 18.81 & 11 & 121.33 & 35 & -14 \\
\hline AZ 06A-26 & Koturdag & $\begin{array}{l}\text { Pool with gas seeping on the western contact crater- } \\
\text { stiff extruded breccia, ice crust locally present }\end{array}$ & 15 & 401 & 29 & $<1$ & 144 & 4257 & 8 & $<1$ & 11 & $<1$ & 3235 & 16 & 5266 & $<1$ & 0.76 & 199.25 & 262.21 & 215.47 & -8.75 & -78 \\
\hline $\mathrm{AZ} 06 \mathrm{~A}-27 \mathrm{U}$ & Koturdag & $\begin{array}{l}\text { Pool w } \\
\text { stiff ex }\end{array}$ & 20 & 8 & 47 & 1 & 42 & 34 & 12 & $<1$ & $<1$ & $<1$ & 11 & 34 & 308 & $<1$ & 0.74 & 301 & .00 & 261.93 & -8.79 & 9 \\
\hline $\mathrm{AZ} 06 \mathrm{~A}-27$ & Koturdag & $\begin{array}{l}\text { Pool with gas seeping on the eastern contact crater- } \\
\text { stiff extruded breccia, ice crust locally present }\end{array}$ & 20 & 82 & 55 & 2 & 311 & 7192 & 10 & $<1$ & $<1$ & $<1$ & 5158 & 35 & 9819 & $<1$ & 0.72 & 48.73 & 207.38 & 254.69 & -8.81 & -72 \\
\hline Seawater & Caspian Sea & & & & 90 & & 817 & 3250 & & & & & 5650 & 9 & 3167 & & & 627.78 & 361.11 & & & \\
\hline
\end{tabular}



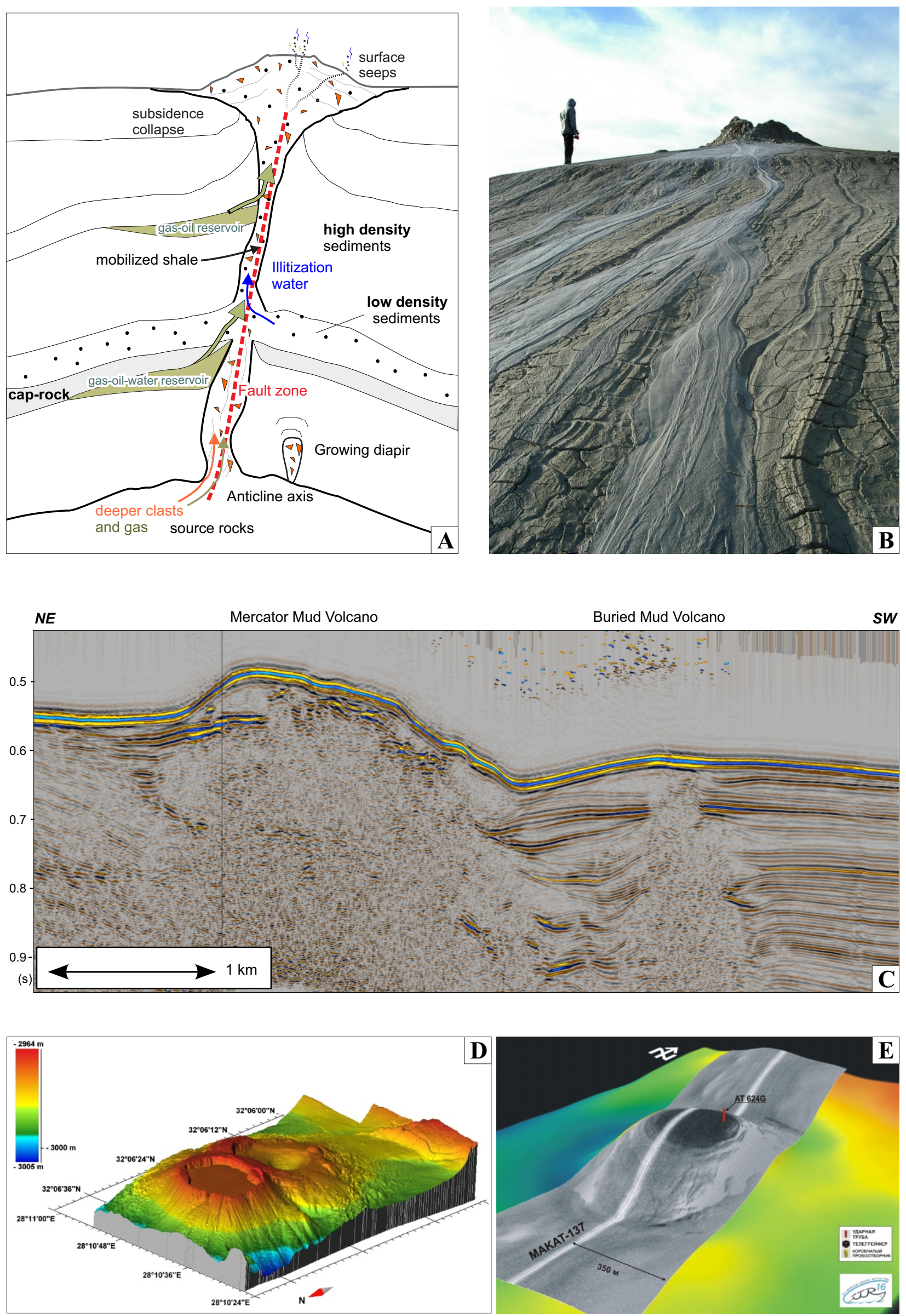


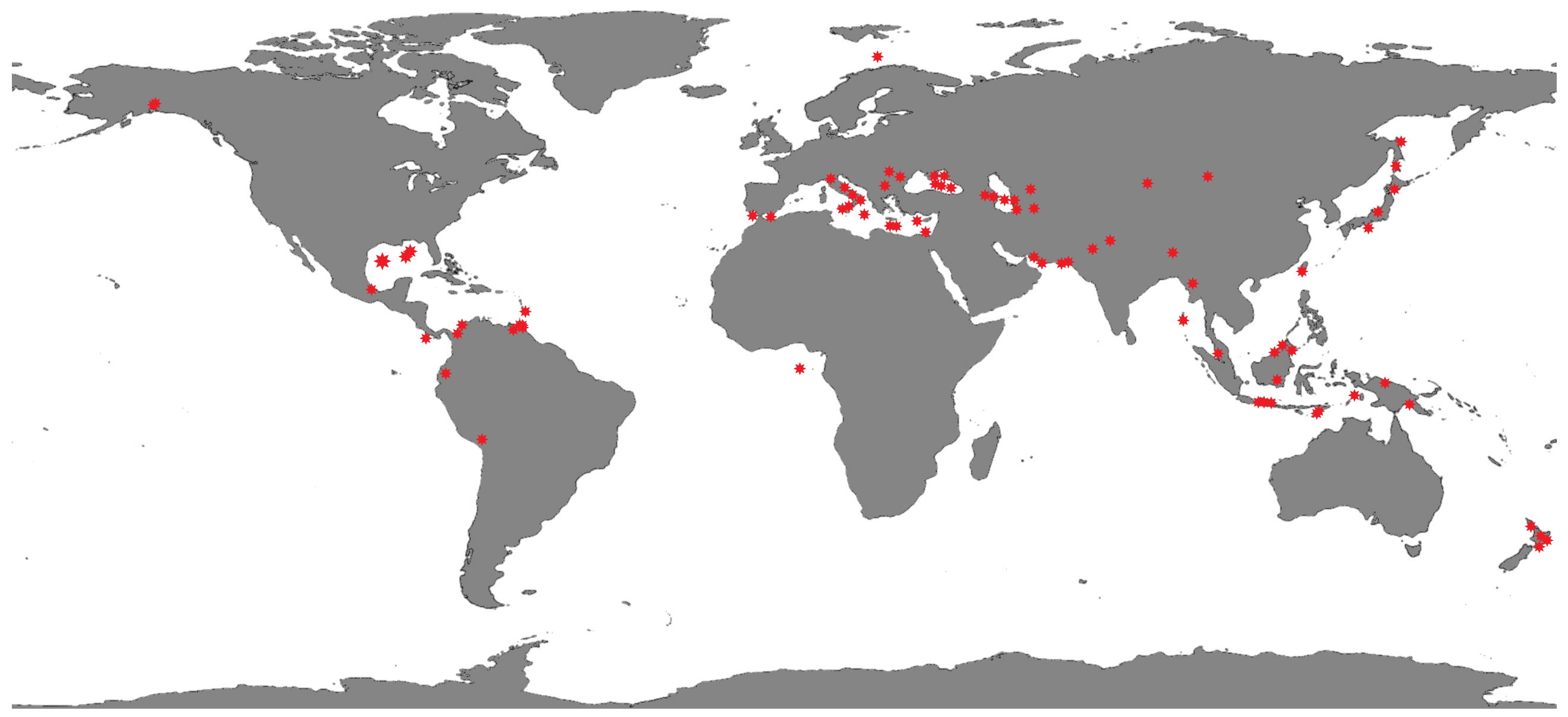



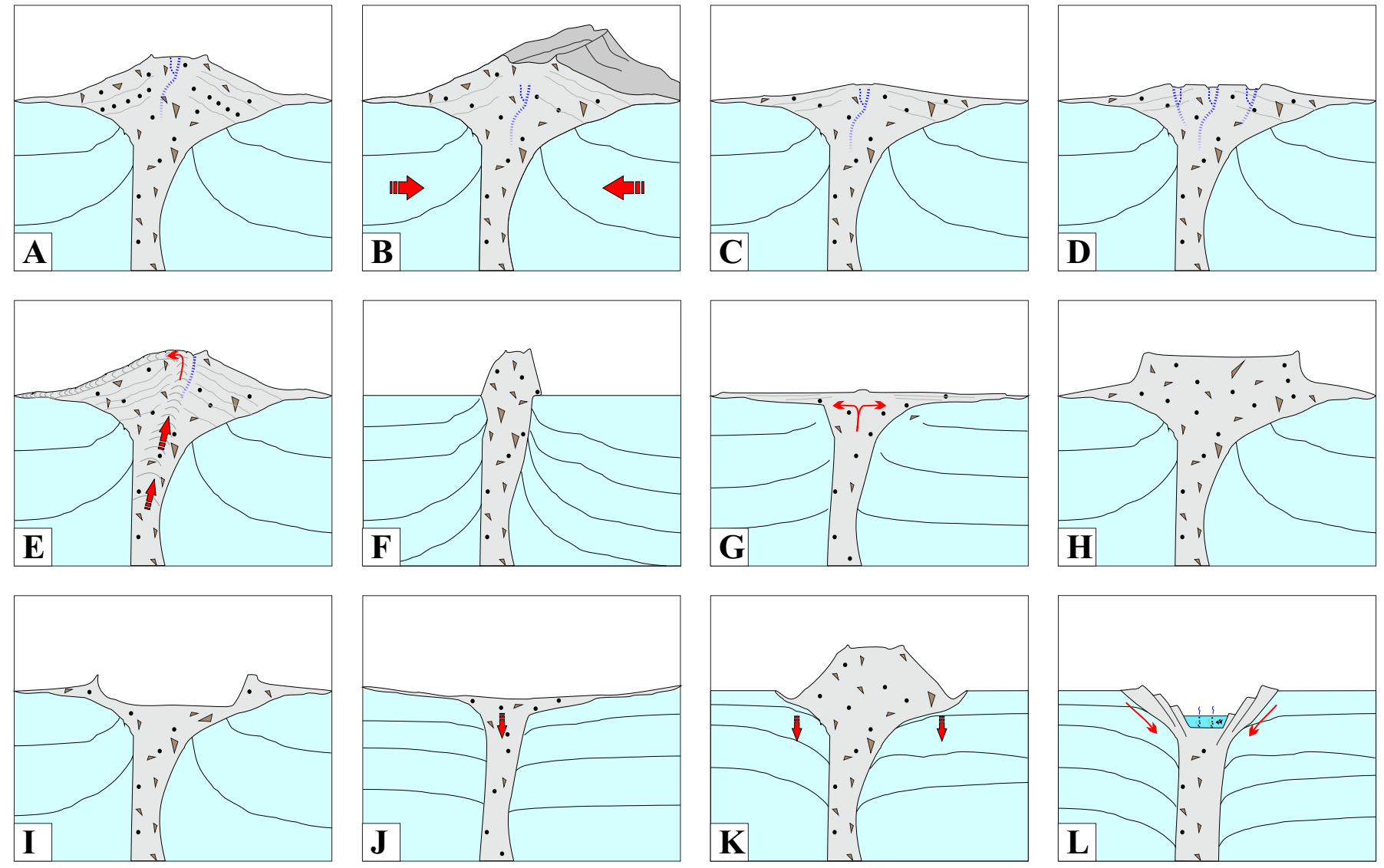

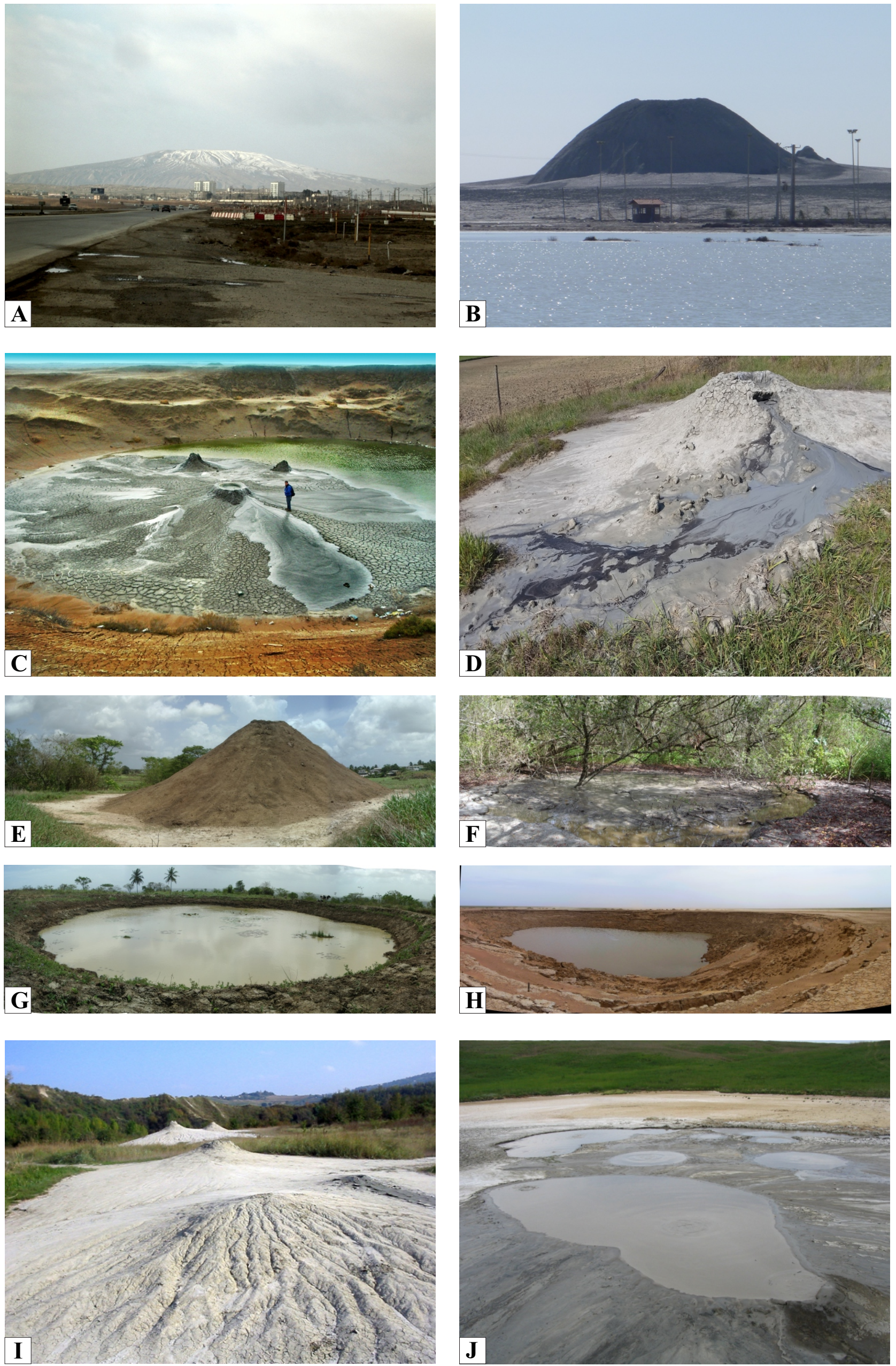

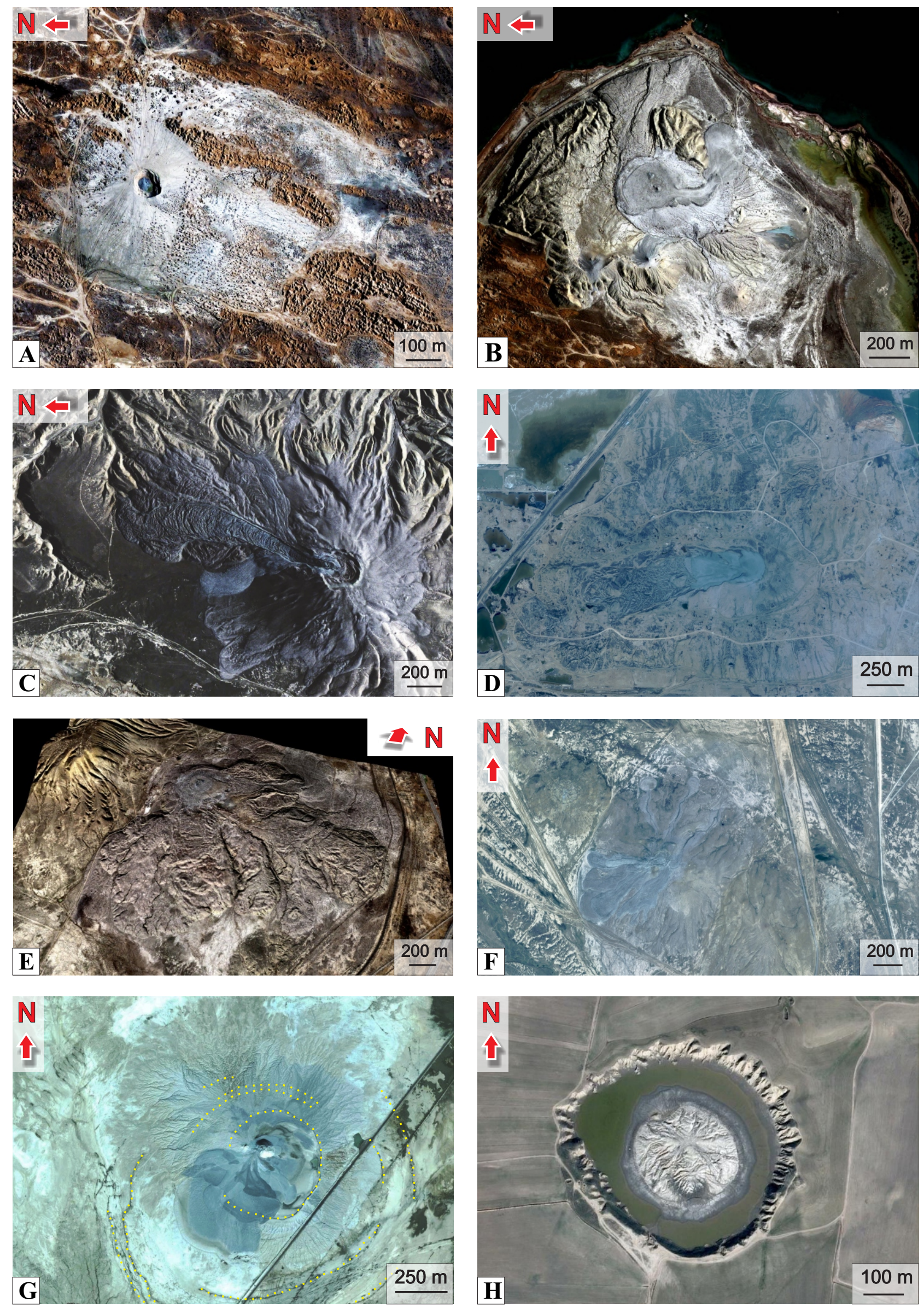

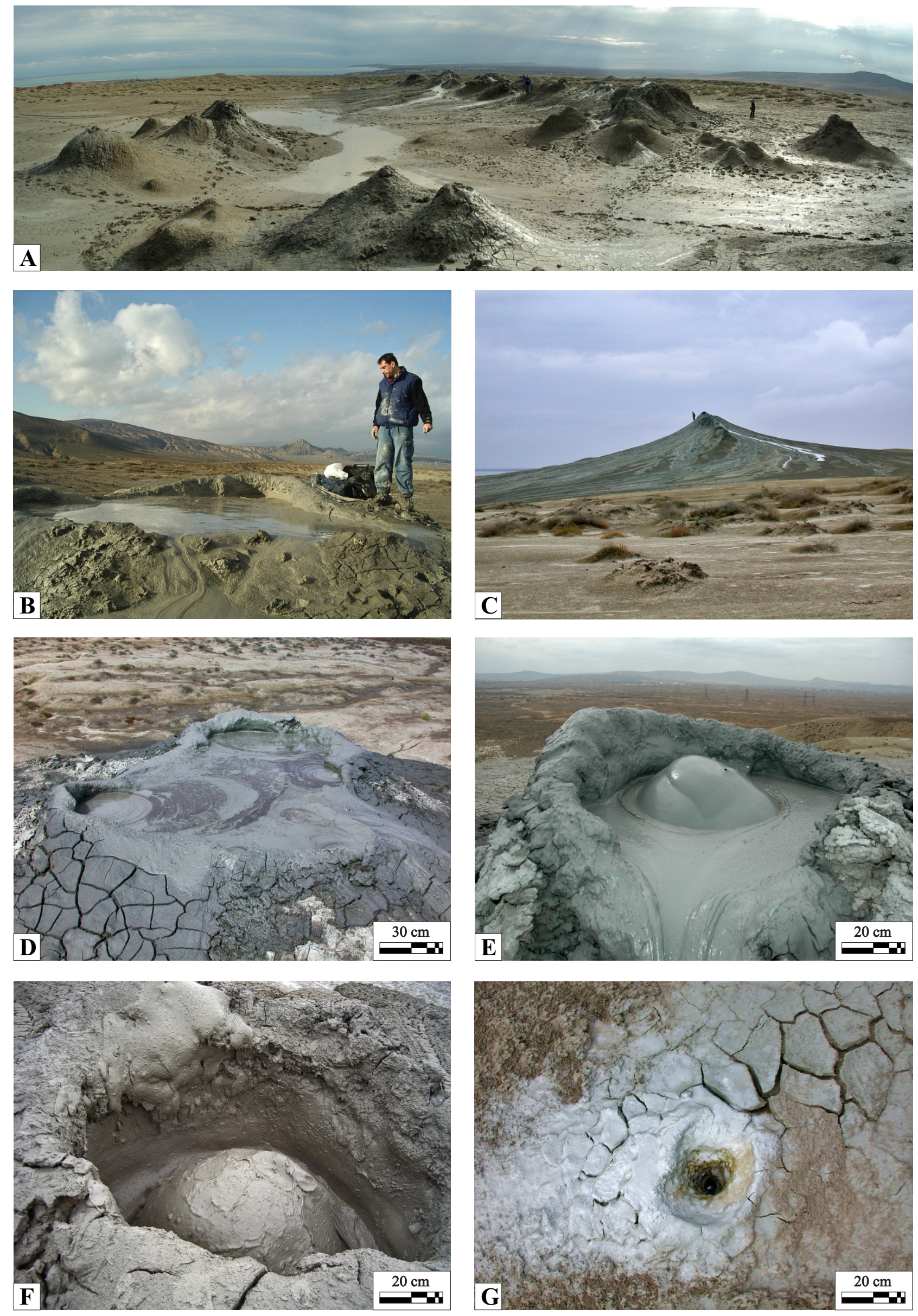

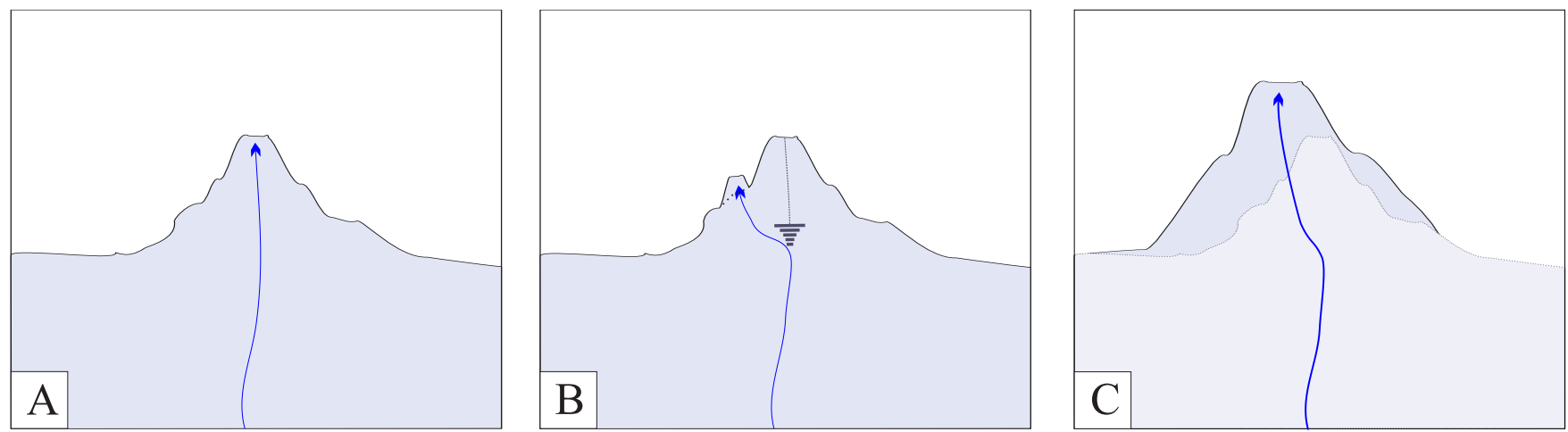

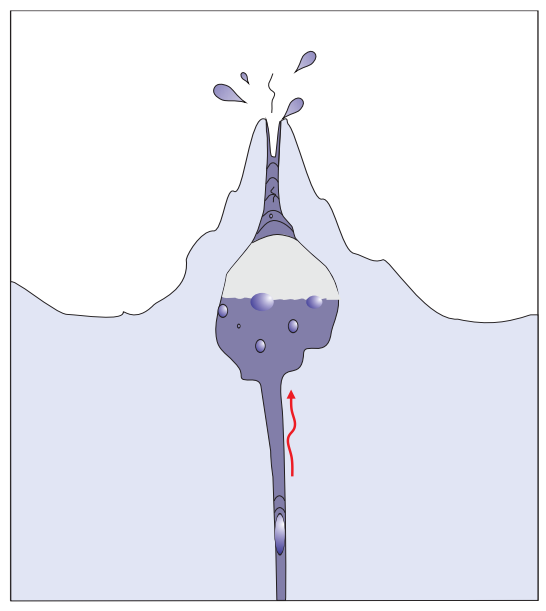

SPLATTERS

$>$ Gas

$<$ Mud

$<$ Water

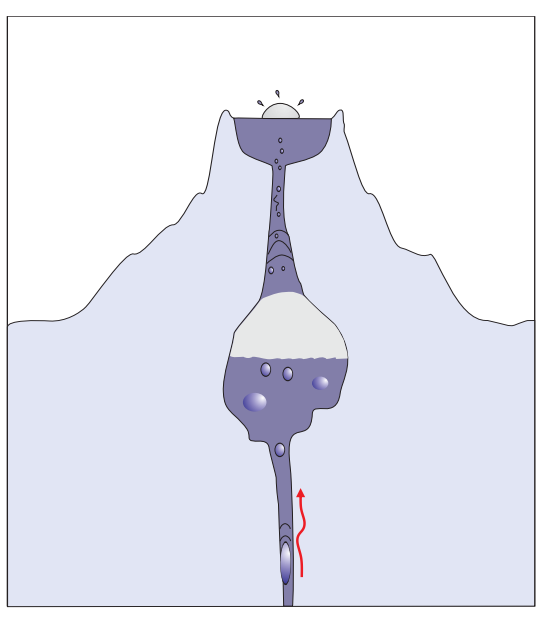

BUBBLERS

$>$ Mud

$<$ Water

$<$ Gas

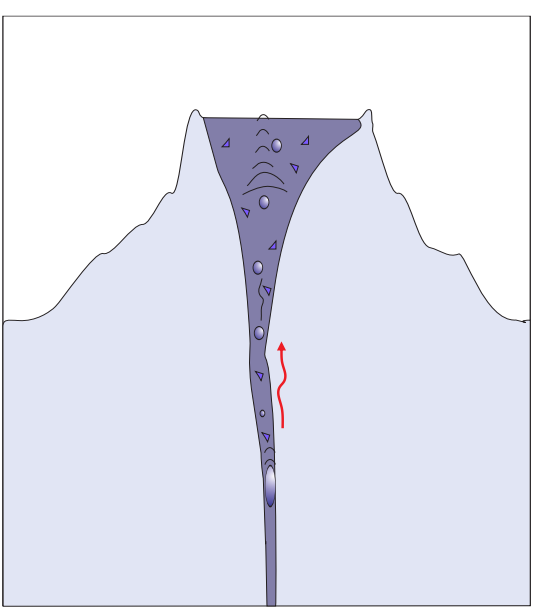

CLAST-RICH

$>$ Mud breccia

< Water

$<$ Gas 

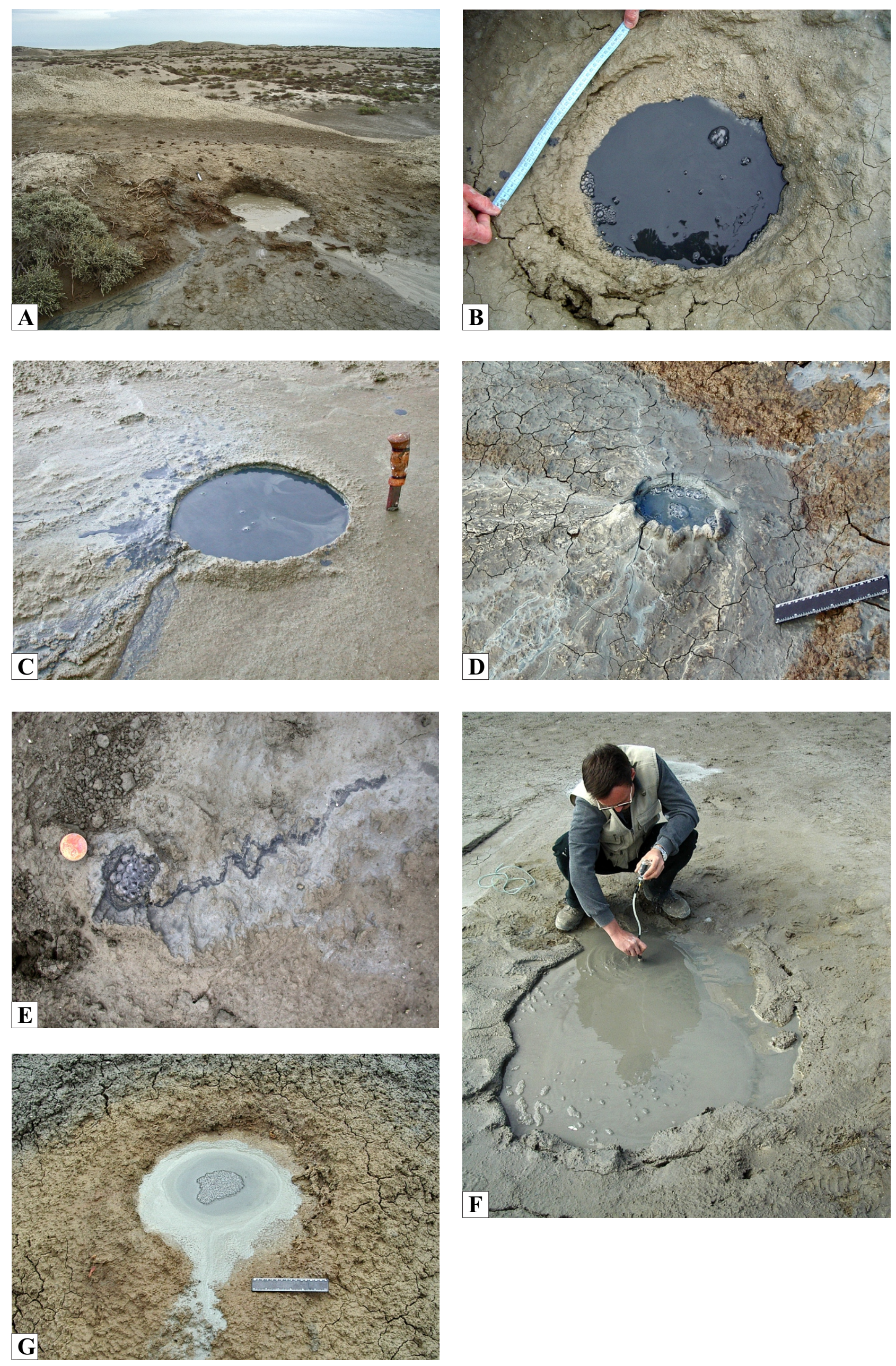

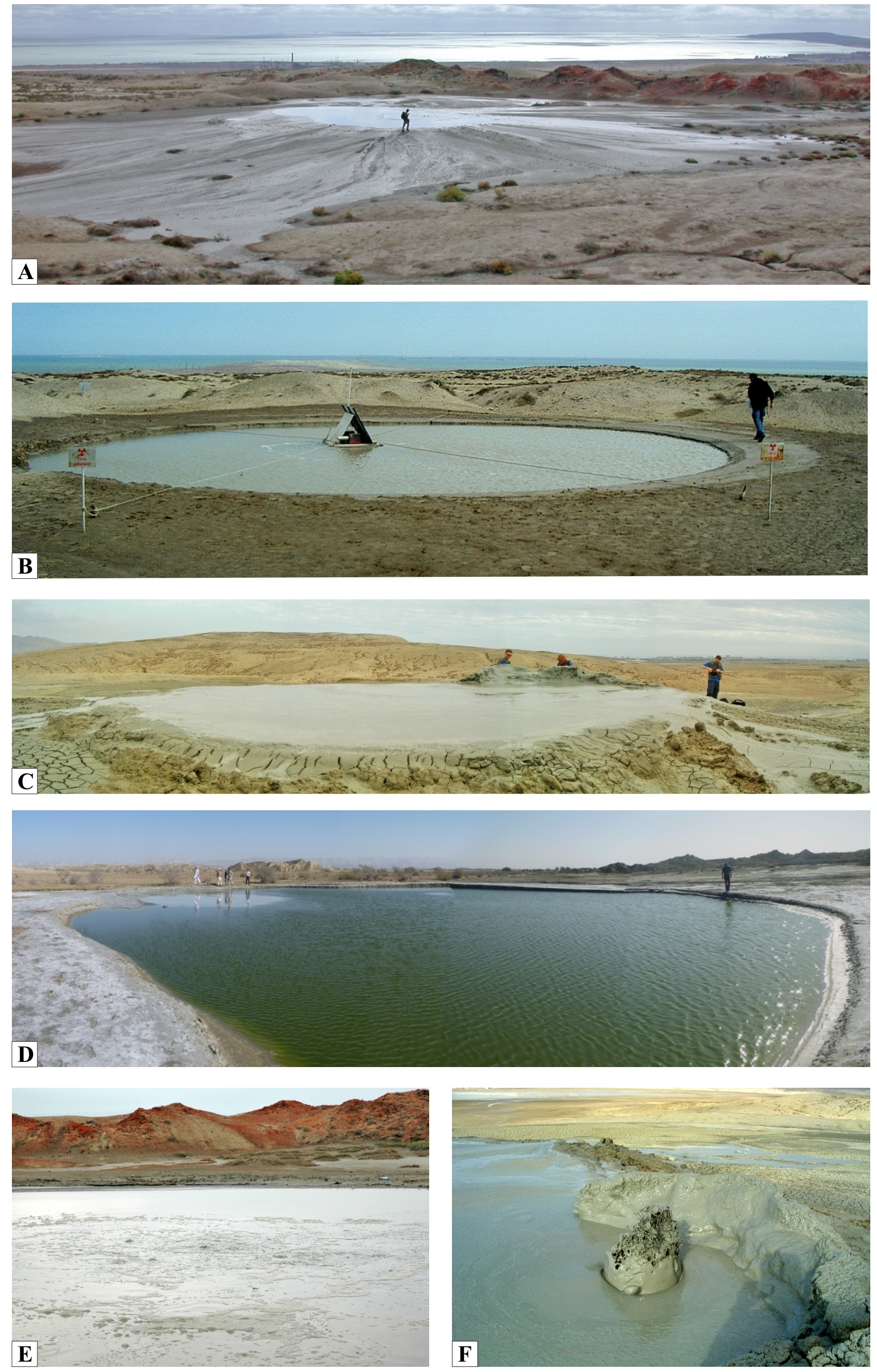

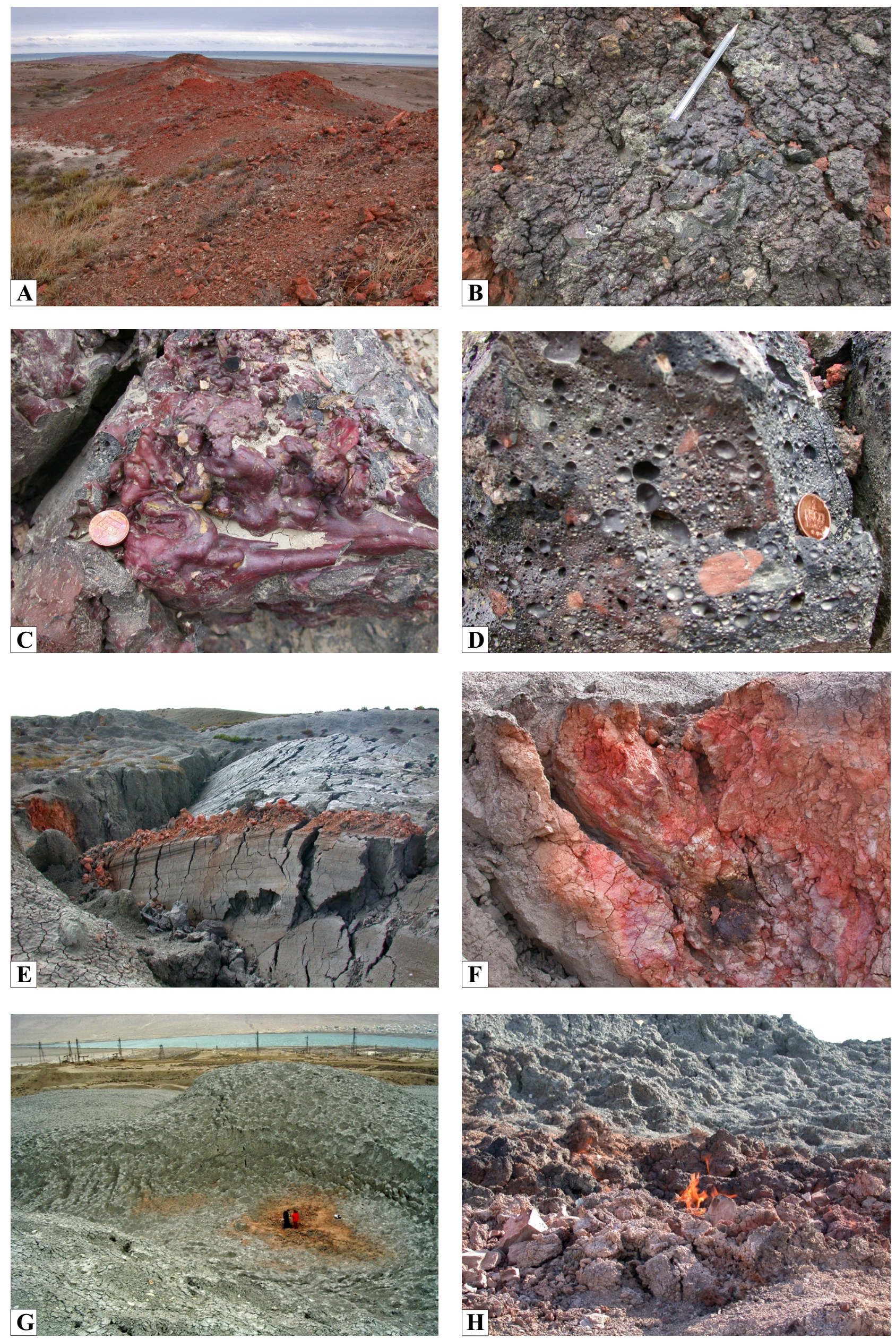


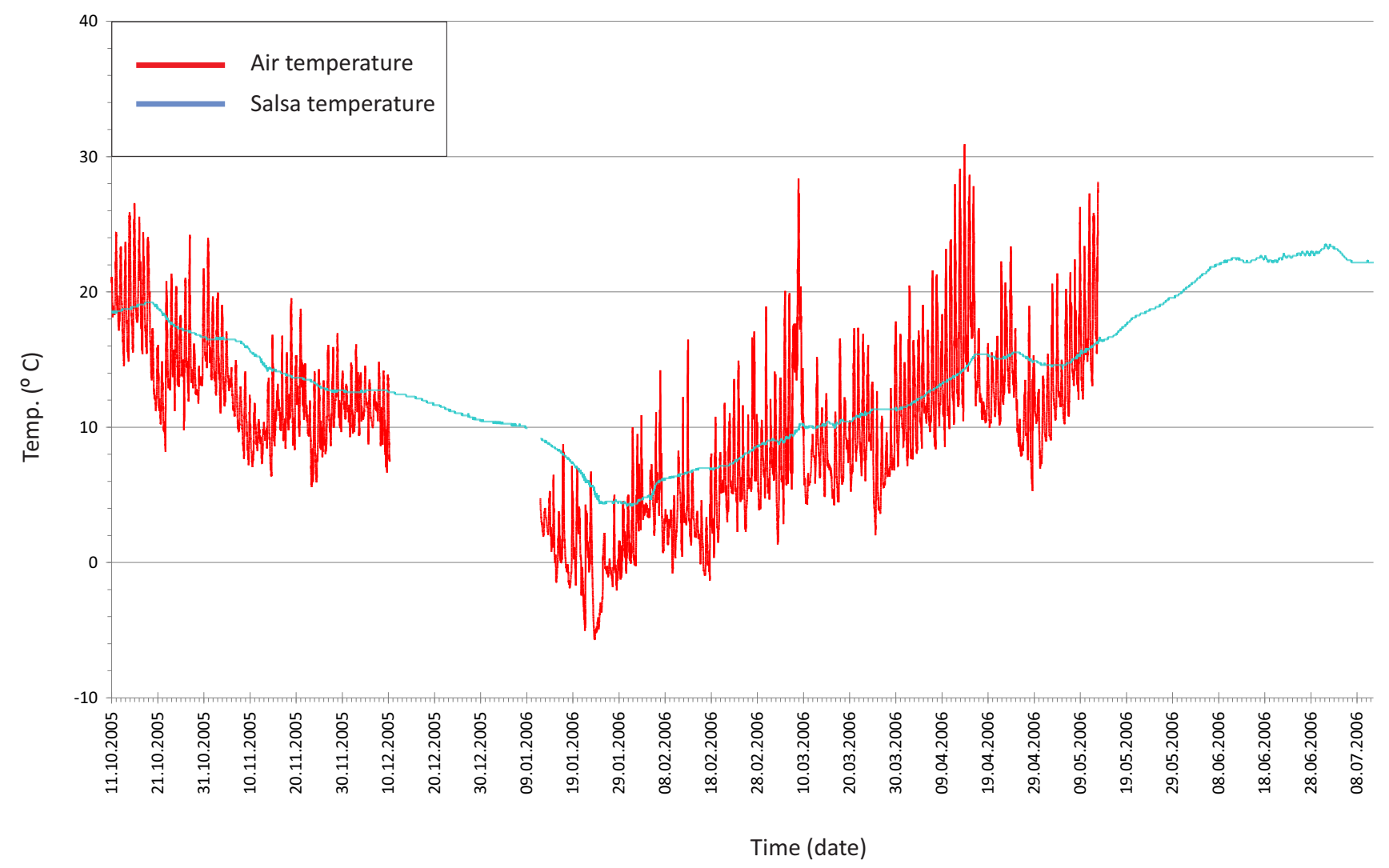



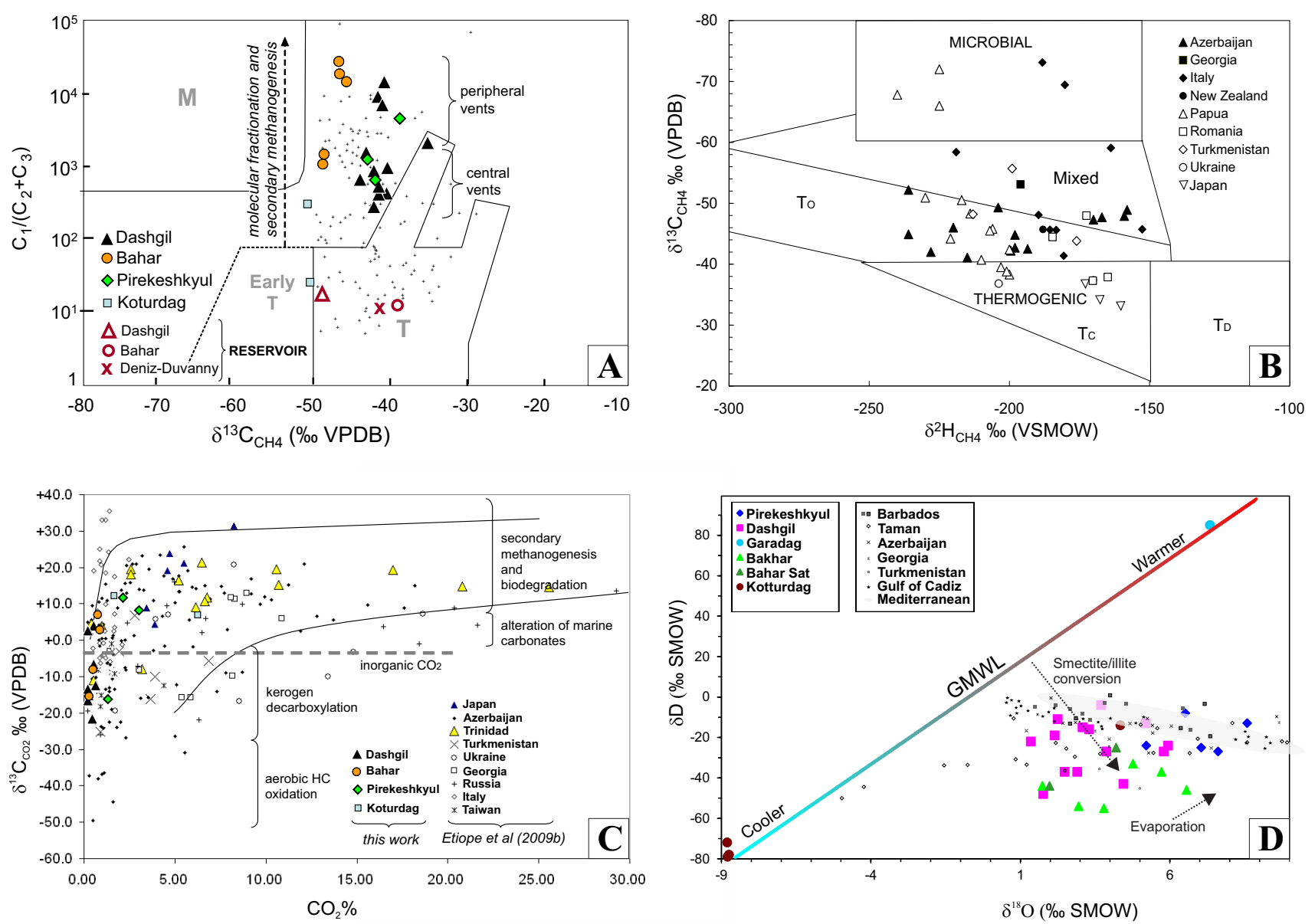

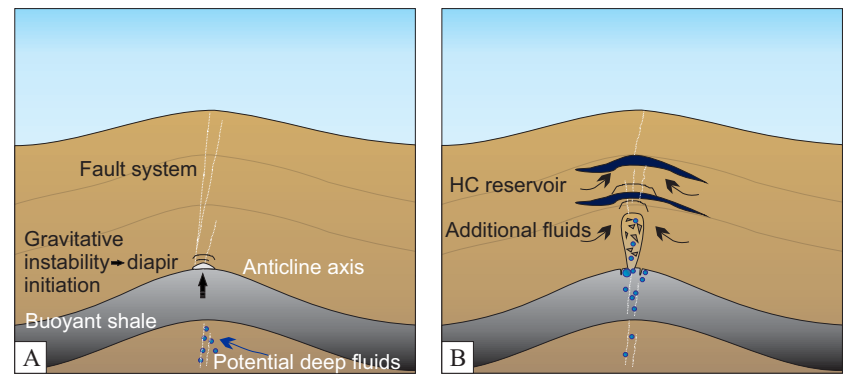

Diapir initiation in buoyant shales with potential deep fluids migration along structural highs (e.g. anticline axes) or fault networks

Fluids migration from different units and overpressure increase, diapiric structure development and brecciation during
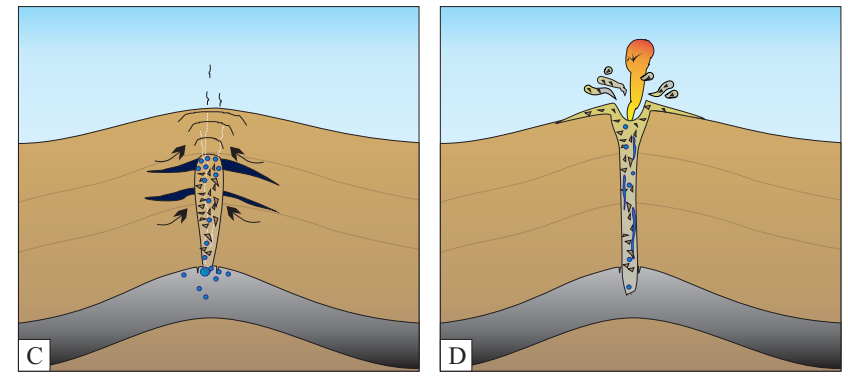
its growth
Overpressured diapir reaches critical depth. Overburden cannot contain fluids rich diapir. System in unstable conditions ready for triggering
Blast of gas. The sudden pressure release allows large amount of fluidized and gas saturated sediments to reach the surface 


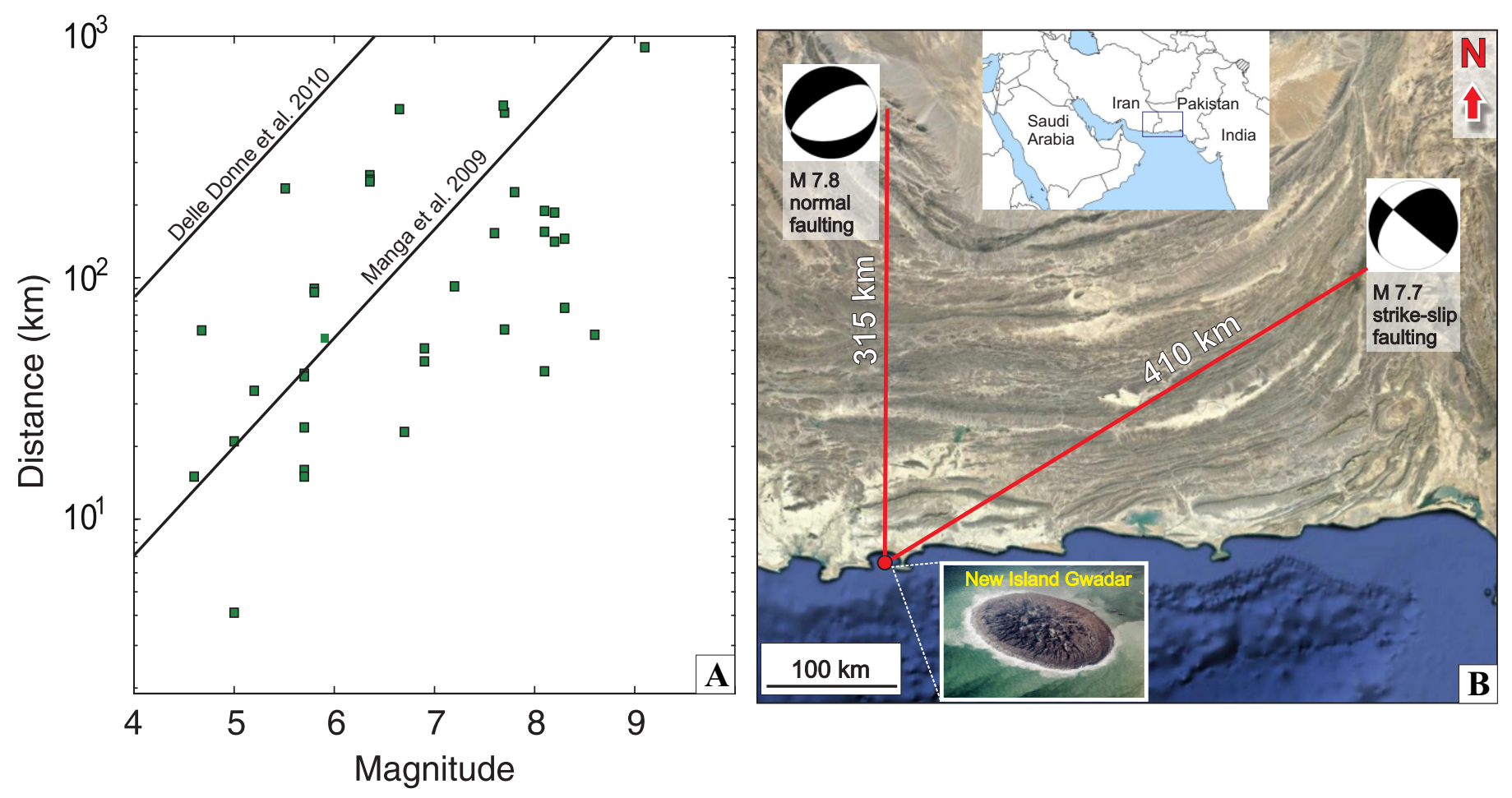



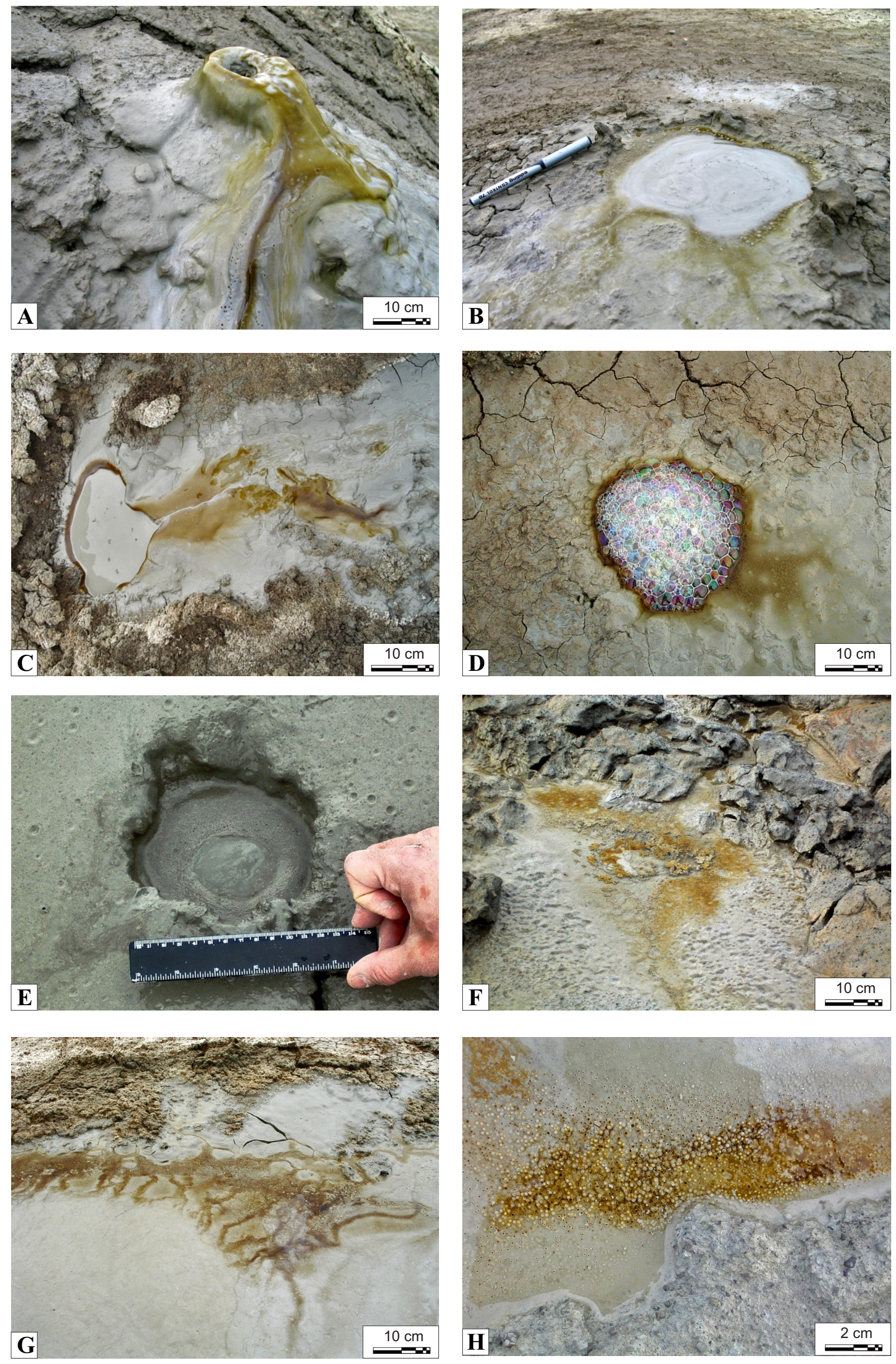